\title{
Asymmetric Total Synthesis of Arcutinidine and Arcutinine
}

Shupeng Zhou, Kaifu Xia, Ang Li

Submitted date: 30/05/2019 Posted date: 30/05/2019

Licence: CC BY-NC-ND 4.0

Citation information: Zhou, Shupeng; Xia, Kaifu; Li, Ang (2019): Asymmetric Total Synthesis of Arcutinidine and Arcutinine. ChemRxiv. Preprint.

We have accomplished the asymmetric total synthesis of arcutinidine and arcutinine, two arcutine-type C20-diterpenoid alkaloids. A pentacyclic intermediate was rapidly assembled by using two Diels-Alder reactions. A cascade sequence of Prins cyclization and Wagner-Meerwein rearrangement was then developed to construct the core of arcutinidine, which was further elaborated into an oxygenated pentacycle through a scalable route. Chemoselective reductive amination followed by spontaneous imine formation furnished the pyrroline motif at a final stage.

File list (2)

Asymmetric Total Synthesis of Arcutinidine and Arcutinin... (848.42 KiB) view on ChemRxiv • download file 


\title{
Asymmetric Total Synthesis of Arcutinidine and Arcutinine
}

\author{
Shupeng Zhou, Kaifu Xia, and Ang Li* \\ State Key Laboratory of Bioorganic and Natural Products Chemistry, Center for Excellence in Molecular Synthesis, \\ Shanghai Institute of Organic Chemistry, University of Chinese Academy of Sciences, Chinese Academy of Sciences, \\ 345 Lingling Road, Shanghai 200032, China
}

Supporting Information Placeholder

\begin{abstract}
We have accomplished the asymmetric total synthesis of arcutinidine and arcutinine, two arcutine-type C2o-diterpenoid alkaloids. A pentacyclic intermediate was rapidly assembled by using two Diels-Alder reactions. A cascade sequence of Prins cyclization and Wagner-Meerwein rearrangement was then developed to construct the core of arcutinidine, which was further elaborated into an oxygenated pentacycle through a scalable route. Chemoselective reductive amination followed by spontaneous imine formation furnished the pyrroline motif at a final stage.
\end{abstract}

The $\mathrm{C}_{20}$-diterpenoid alkaloids ${ }^{1}$ have long been attractive targets for chemical synthesis from the structural and biological perspectives. ${ }^{2}$ Among them, members from the atisine, ${ }^{3}$ hetisine,${ }^{4}$ denudatine, ${ }^{5}$ veatchine, ${ }^{6}$ napelline, ${ }^{7}$ and hetidine ${ }^{8,9}$ subclasses have been conquered by synthetic chemists. Nearly two decades ago, Bassonova and co-workers reported the discovery of two intricate $\mathrm{C}_{20}$-diterpenoid alkaloids arcutine (1, Figure 1) and arcutinine (2) and their presumed biogenetic precursor arcutinidine (3). Their scaffold possesses two doubly fused bicyclo[2.2.2] octane moieties (Figure 1; highlighted in blue) and a congested pyrroline motif. ${ }^{10}$ Of note, a nonalkaloidal natural product atropurpuran (4) relevant to 1-3 was later discovered by Wang and colleagues. " Compared to the alkaloids, diterpenoid 4 has drawn considerable attention from the synthesis community. ${ }^{12-14}$ Suzuki et al. first disclosed an inspiring approach for construction of the core of $4{ }^{12 a}$ and the Qin ${ }^{13}$ and $\mathrm{Xu}^{14}$ groups recently accomplished elegant syntheses of this molecule in a racemic form, respectively. Obviously, the pyrroline and tertiary alcohol within the alkaloids pose an additional challenge for chemical synthesis. Right before our submission of this paper, Qin and coworkers disclosed a beautiful enantioselective synthesis of arcutinidine and arcutinine. ${ }^{15}$ During the course of our synthesis of hetidine type alkaloids, ${ }^{9}$ we were intrigued by the relationship between the hetidine and arcutine skeletons. Wang and Liang recognized the arcutine skeleton as a rearrangement product of the hetidine or hetisine skeleton. ${ }^{\text {a }}$ More specifically, Sarpong and colleagues proposed a Wagner-Meerwein type 1,2-alkyl shift (Figure 1; key bonds highlighted in red) responsible for the biogenesis of the arcutine skeleton from the hetidine skeleton, and carried out DFT calculations to support this insightful hypothesis. ${ }^{16}$ Indeed, tongolinine (5) bearing a tertiary alcohol may serve as a precursor of the carbocation species required for initiating the
Wagner-Meerwein pathway. Our experience ${ }^{17}$ with Prins reaction suggested an opportunity to generate a carbocation species at the end of this powerful $\mathrm{C}-\mathrm{C}$ bond forming reaction. ${ }^{18}$ Herein, we report an asymmetric total synthesis of $\mathbf{1}$ and $2 .{ }^{19}$
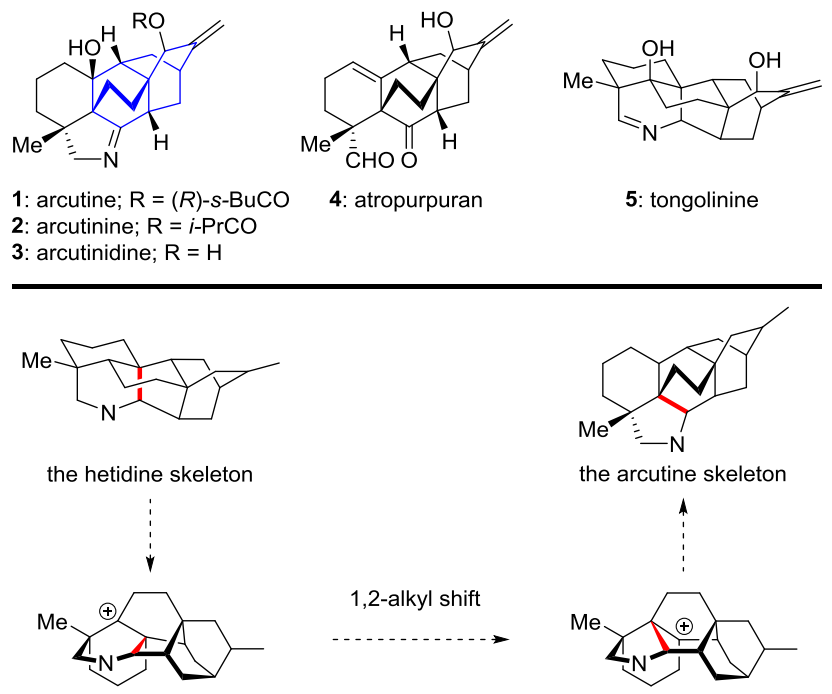

Figure 1. The structures of representative arcutine type alkaloids (1-3) and related natural products [atropurpuran (4) and tongolinine (5)] and the postulated biogenetic relationship between the hetidine and arcutine skeletons.

We first undertook a retrosynthetic analysis of $\mathbf{1}$ (Figure 2). Disassembly of the pyrroline within 1 gave diketoaldehyde 6; chemoselective reductive amination of the aldehyde functionality of $\mathbf{6}$ could be a challenge at a late stage of the synthesis. ${ }^{9}$ Compound $\mathbf{6}$ may arise from less oxygenated intermediate 7. Position-selective $\mathrm{C}-\mathrm{H}$ oxidation of the latter would furnish the corresponding lactone, and the quaternary $\mathrm{C}_{4}$ could be constructed through $\alpha$-methylation. A key retrosynthesis step from 7 to compound $\mathbf{8}$ bearing a simplified hetidine framework relied on the design of a cascade sequence of Prins cyclization and Wagner-Meerwein rearrangement. ${ }^{20}$ The MOM group of $\mathbf{8}$ was expected to serve as a precursor of the oxonium ion species that would initiate the 6-endo-trig cyclization. Upon formation of the $\mathrm{C}-\mathrm{C}$ bond highlighted in blue (Figure 2), the resultant tertiary carbocation at $C_{5}$ should induce the 1,2-alkyl shift to construct the $\mathrm{C}-\mathrm{C}$ bond highlighted in red (Figure 2 ). On the basis of our experience of septedine synthesis, ${ }^{9}$ the bicyclo[2.2.2] octane 
moiety of $\mathbf{8}$ could be assembled through an anionic Diels-Alder cycloaddition. Therefore, $\alpha, \beta$-unsaturated enone 9 was considered a suitable precursor of $\mathbf{8}$. Further simplification led to aldehyde 10, which may result from an intermolecular Diels-Alder reaction ${ }^{21}$ of known diene $\mathbf{1 1}^{22}$ and dienophile 12. The latter was traced back to known enantioenriched alcohol 13 that was readily available through lipase-mediated resolution. ${ }^{23}$

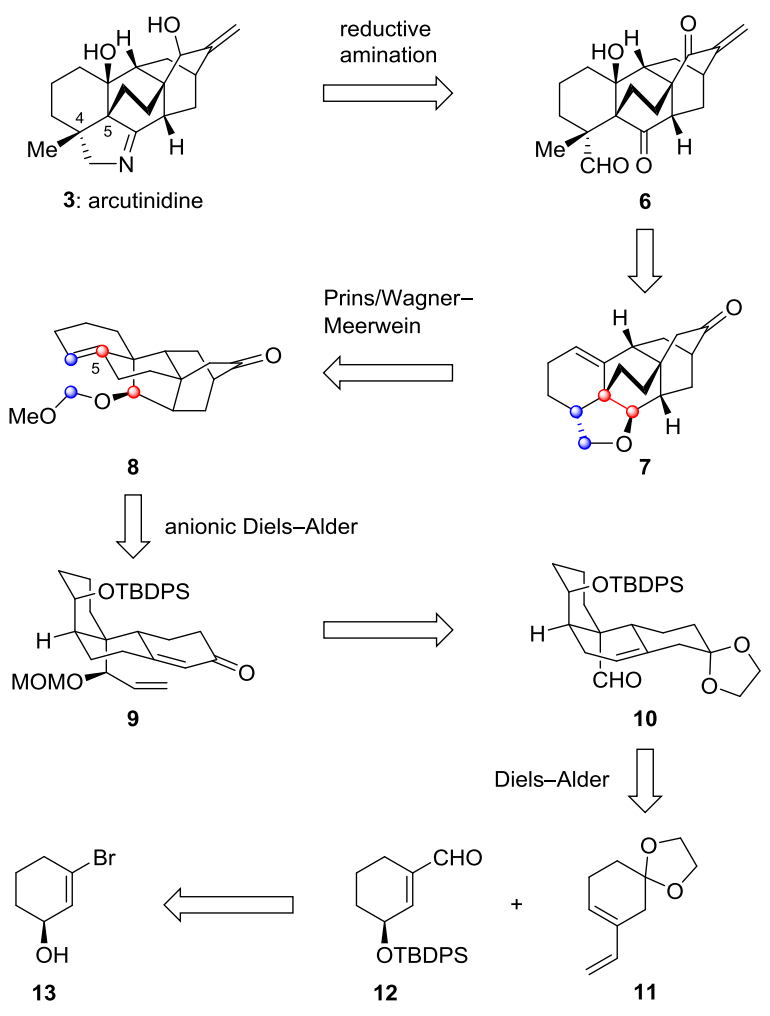

Figure 2. Retrosynthetic analysis of 3.

The synthesis commenced with scalable preparation of pentacyclic intermediate $\mathbf{8}$ (Scheme 1). Silylation of enantioenriched alcohol $\mathbf{1 3}$ (>99\% ee) provided compound $\mathbf{1 4}$ in $93 \%$ yield. Treatment of $\mathbf{1 4}$ with $t$-BuLi generated the alkenyl lithium species, which was quenched by DMF to give aldehyde 12 in $91 \%$ yield. We then examined a variety of conditions for the intermolecular Diels-Alder reaction of $\mathbf{1 1}$ and 12; acid lability of the ketal group of the former turned out to be a problem. To our delight, $\mathrm{BF}_{3} \cdot \mathrm{OEt}_{2}$ was found to be an effective promoter for the cycloaddition at $-78^{\circ} \mathrm{C}$, and compound 10 was obtained in $68 \%$ isolated yield. One-pot vinyllithium addition and MOM protection afforded allylic ether $\mathbf{1 5}$ in $85 \%$ yield as a single detectable diastereomer. Exposure to aq. $\mathrm{HClO}_{4}$ resulted in selective hydrolysis of the ketal followed by $\mathrm{C}=\mathrm{C}$ bond migration, furnishing $\alpha, \beta$ unsaturated enone 9 in $72 \%$ yield. Following from our experience with the anionic $[4+2]$-cycloaddition, ${ }^{9}$ we subjected 9 to deprotonation with LiHMDS. The resultant 1,3-dienolate underwent an intramolecular Diels-Alder reaction at $22{ }^{\circ} \mathrm{C}$, and subsequent desilylation of the cycloadduct with TBAF provided alcohol 16 in $84 \%$ overall yield. Of note, complete removal of $\mathrm{O}_{2}$ in the reaction system by the freeze-pump-thaw cycling was crucial to the success of this anionic cycloaddition. X-ray crystallographic analysis of $\mathbf{1 6}$ (Scheme 1) confirmed the stereochemical outcomes of the two Diels-Alder reactions. Dehydration of 16 with
$\mathrm{SOCl}_{2} /$ pyridine gave trisubstituted olefin 8 in $76 \%$ yield. ${ }^{17 a}$ Indeed, $\mathbf{8}$ could also serve as a versatile intermediate for the synthesis of hetidine type alkaloids.

\section{Scheme 1. Construction of Pentacyclic Intermediate 8}

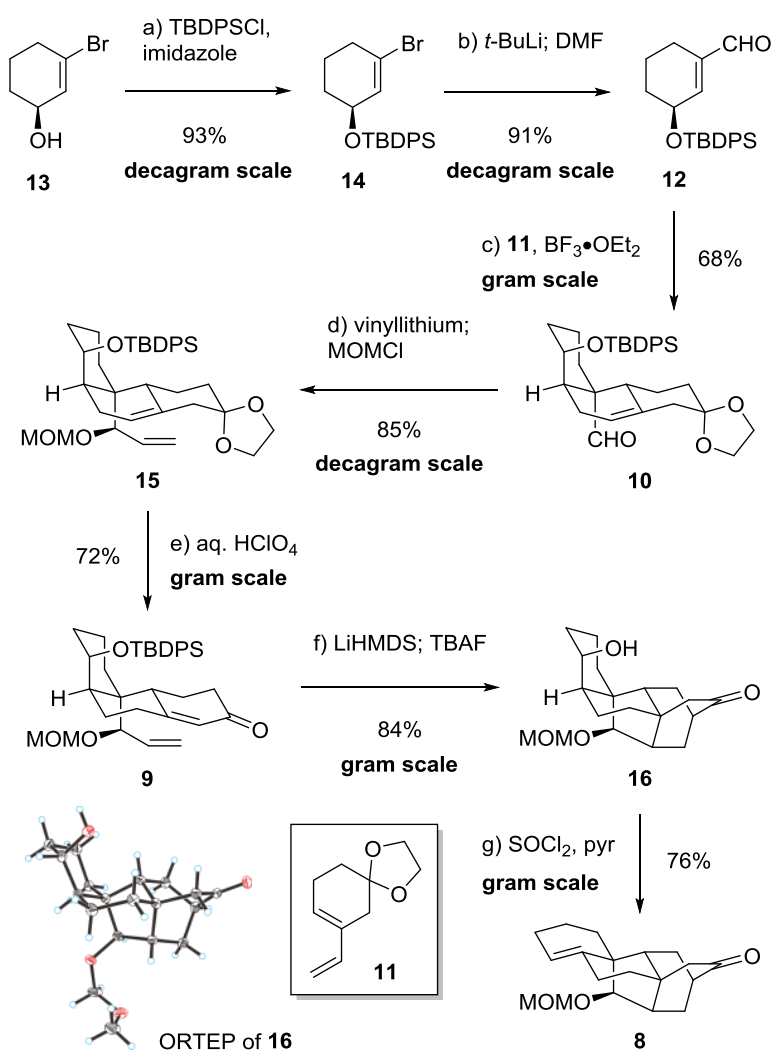

Table 1. Conditions for the Cationic Cascade Reaction

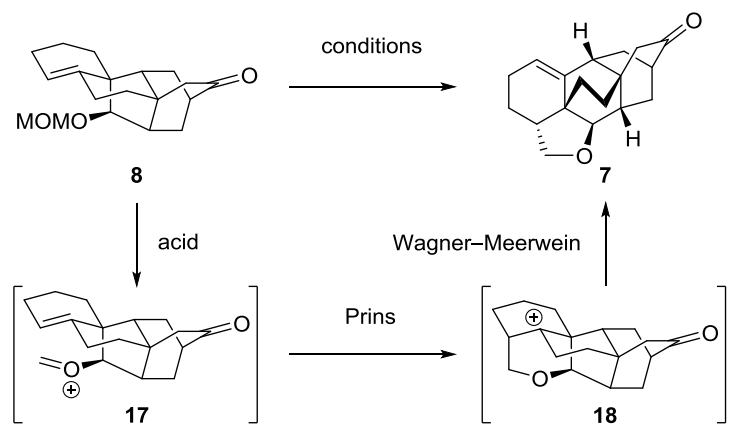

\begin{tabular}{clc}
\hline entry & conditions $^{a}$ & yield (\%) \\
\hline 1 & $\mathrm{TFA}^{\circ} \mathrm{o}^{\circ} \mathrm{C}, 24 \mathrm{~h}$ & 22 \\
2 & $\mathrm{TESOTf}^{\circ}{ }^{\circ} \mathrm{C}, 1 \mathrm{~h}$ & 16 \\
3 & $\mathrm{BF}_{3} \cdot \mathrm{OEt}_{2},-15^{\circ} \mathrm{C}, 6 \mathrm{~h}$ & 37 \\
4 & $\mathrm{TiCl}_{4},-15{ }^{\circ} \mathrm{C}, 1 \mathrm{~h}$ & 24 \\
5 & $\mathrm{SnCl}_{4},-15{ }^{\circ} \mathrm{C}, 1 \mathrm{~h}$ & 63 \\
6 & $\mathrm{SnCl}_{4}, \mathrm{TMSOAc},-15{ }^{\circ} \mathrm{C}, 1 \mathrm{~h}$ & 55 \\
\hline
\end{tabular}

${ }^{a}$ 1.o equiv. acid. Reactions performed in $\mathrm{CH}_{2} \mathrm{Cl}_{2}$.

With a large quantity of $\mathbf{8}$ in hand, we investigated the conditions for its conversion into 7 ; the results are summarized in Table 1 . In the presence of a suitable, stoichiometric acid promoter, 8 should undergo a Prins/Wagner-Meerwein cascade to give 7 bearing an arcutine scaffold, presumably via the intermediacy of two cationic species 17 and 18. To our 
delight, exposure of 8 to TFA gave $\mathbf{7}$ in $22 \%$ yield (entry 1), despite a significant amount of the alcohol resulting from MOM deprotection. TESOTf caused severe substrate decomposition (entry 2) $\mathrm{BF}_{3} \cdot \mathrm{OEt}_{2}$ slightly increased the yield of $\mathbf{7}$ (entry 3), while $\mathrm{TiCl}_{4}$ preferentially led to MOM removal (entry 4 ). $\mathrm{SnCl}_{4}$ was then found to be an optimal promoter for the cascade reaction, and 7 was obtained in $63 \%$ yield on a gram scale (entry 5 ). We briefly explored the possibility of trapping the post-rearrangement carbocation species with an oxygen nucleophile (TMSOAc); however, proton elimination (leading to olefin 7) remained the predominant reaction pathway (entry 6).

\section{Scheme 2. Preparation of Oxygenated Pentacycle 6}
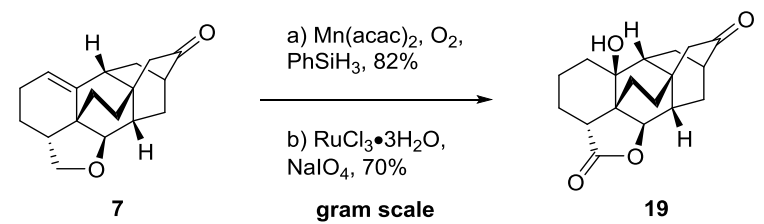

gram scale
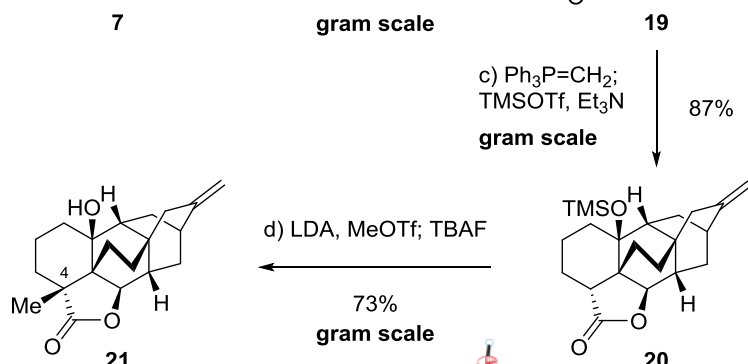

d) LDA, MeOTf; TBAF
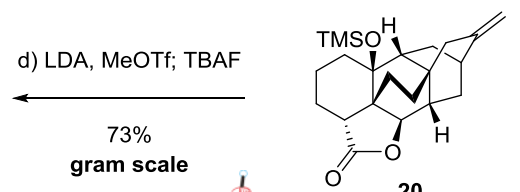

$$
81 \% \downarrow \begin{aligned}
& \text { e) } \mathrm{SeO}_{2}, \mathrm{TBHP} \\
& \text { gram scale }
\end{aligned}
$$

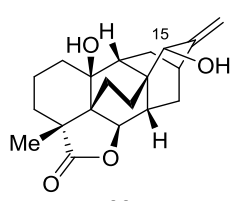

22
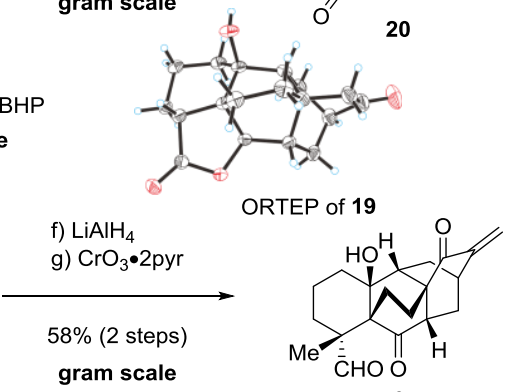

6
We then developed a robust route from 7 to oxygenated pentacycle 6 (Scheme 2). Face-selective Mukaiyama hydration of the trisubstituted olefin followed by position-selective $\mathrm{C}-\mathrm{H}$ oxidation using the Sharpless protocol ${ }^{24}\left(\mathrm{RuCl}_{3} \cdot{ }_{3} \mathrm{H}_{2} \mathrm{O}\right.$, $\mathrm{NaIO}_{4}$ ) afforded alcohol 19, the structure of which was confirmed by X-ray crystallographic analysis (Scheme 2). Of note, $\mathrm{Mn}$ (acac) ${ }_{2}{ }_{2}^{25}$ was superior to $\mathrm{Co}(\text { acac })_{2}$ as a precatalyst for this particular olefin hydration. The alcohol underwent one-pot Wittig methylenation and silylation to give compound 20 in $87 \%$ yield. $\alpha$-Methylation of this lactone turned out to be a challenge; MeI was ineffective under various conditions. To our delight, MeOTf proved to be a more powerful reagent in this case. $^{26}$ The lithium enolate of $\mathbf{2 0}$ was methylated smoothly in the presence of HMPA, and desilylation with TBAF furnished alcohol $\mathbf{2 1}$ in one pot with good overall efficiency. The stereochemistry at $\mathrm{C}_{4}$ was secured by the rigid polycyclic system. Oxidation of 21 with $\mathrm{SeO}_{2} / \mathrm{TBHP}$ gave allylic alcohol 22 in $81 \%$ yield as an undesired diastereomer, which was then subjected to a sequence of $\mathrm{LiAlH}_{4}$ reduction and $\mathrm{CrO}_{3} \cdot 2$ pyr oxidation. ${ }^{27}$ Thus, diketoaldehyde 6 was obtained in $58 \%$ overall yield. We expected to address the stereochemical issue at $\mathrm{C}_{15}$ by face-selective ketone reduction at a final stage of the synthesis.
Scheme 3. Completion of the Synthesis of 3 and 2
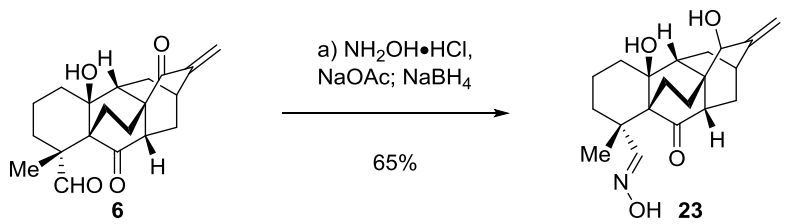

b) $\mathrm{TiCl}_{3}, \mathrm{NaBH}_{3} \mathrm{CN} \downarrow 71 \%$

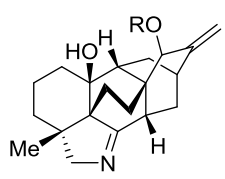

3: arcutinidine; $\mathrm{R}=\mathrm{H}$

2: arcutinine; $\mathrm{R}=i-\mathrm{PrCO}$ c) $i-\mathrm{PrCO}_{2} \mathrm{H}, \mathrm{DCC}$

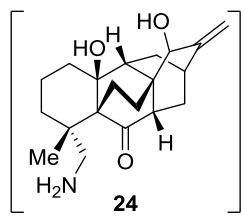

ORTEP of $\mathbf{3}$

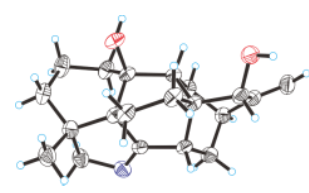

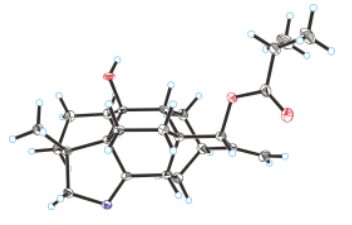

ORTEP of 2
Completion of the synthesis of $\mathbf{3}$ and $\mathbf{2}$ relied on differentiating the reactivity of the three carbonyls of 6 (Scheme 3). Chemoselective condensation of the aldehyde with $\mathrm{NH}_{2} \mathrm{OH}$ followed by face-selective 1,2-reduction of the $\alpha, \beta$ unsaturated enone with $\mathrm{NaBH}_{4}$ afforded compound 23 as a single diastereomer in $65 \%$ yield. The most hindered carbonyl group remained untouched through this reaction sequence. Exposure of 23 to $\mathrm{TiCl}_{3}$ led to reductive cleavage of the $\mathrm{N}-\mathrm{O}$ bond. ${ }^{28}$ The resultant aldimine intermediate was further reduced in situ by $\mathrm{NaBH}_{3} \mathrm{CN}$ to form primary amine $\mathbf{2 4},{ }^{28}$ which underwent spontaneous cyclization upon aqueous workup to give 3 in $71 \%$ yield. Acylation of the allylic alcohol $\left(i-\mathrm{PrCO}_{2} \mathrm{H}, \mathrm{DCC}, \mathrm{DAMP}\right)$ provided 2 in $77 \%$ yield. The structures of $\mathbf{2}$ and 3 were verified by X-ray crystallographic analysis (Scheme 3).

In summary, we have accomplished the asymmetric total synthesis of arcutinidine (3) and arcutinine (2). An expeditious and scalable route to a pentacyclic intermediate with hetidine features was established. A bioinspired Prins/Wagner-Meerwein cascade was then developed for conversion of the hetidine core structure into an arcutine core structure. These endeavors may facilitate studies of the biology of arcutine and hetidine type alkaloids.

\section{AUTHOR INFORMATION}

\section{Corresponding Author}

*ali@sioc.ac.cn

\section{ACKNOWLEDGMENT}

We thank Prof. Richmond Sarpong and Shelby McCowan for discussions. This work was supported by National Natural Science Foundation of China (21525209, 21621002, 21772225, and 21761142003), Chinese Academy of Sciences (Strategic Priority Research Program XDB20oooooo and Key Research Program of Frontier Sciences QYZDB-SSW-SLHo40), Shanghai Science and Technology Commission (17XD140460o), and the K. C. Wong Education Foundation. 


\section{REFERENCES}

(1) (a) Wang, F.-P.; Liang, X.-T. $C_{20}$-Diterpenoid Alkaloids. In The Alkaloids: Chemistry and Biology; Cordell, G. A., Ed.; Elsevier Science: New York, 2002; Vol. 59, pp 1-28o. (b) Wang, F.-P.; Chen, Q.-H.; Liang, X.-T. Diterpenoid alkaloids. Nat. Prod. Rep. 2010, 27, 529.

(2) (a) Cherney, E. C.; Baran, P. S. Terpenoid-alkaloids: their biosynthetic twist of fate and total synthesis. Isr. J. Chem. 2o11, 51, 391. (b) Hamlin, A. M.; Kisunzu, J. K.; Sarpong, R. Synthetic strategies toward hetidine and hetisine-type diterpenoid alkaloids. Org. Biomol. Chem. 2014, 12, 1846. (c) Liu, X.-Y.; Qin, Y. Ongoing pursuit of diterpenoid alkaloids: a synthetic view. Asian J. Org. Chem. 2015, 4, 1010. (d) Zhu, G.-L.; Liu, R.; Liu, B. Total synthesis of atisane-type diterpenoids and related diterpenoid alkaloids. Synthesis 2015, 47, 2691. (e) Liu, X.-Y.; Qin, Y. Enabling syntheses of diterpenoid alkaloids and related diterpenes by an oxidative dearomatization/Diels-Alder cycloaddition strategy. Nat. Prod. Rep. 2017, 34, 1044.

(3) (a) Pelletier, S. W.; Jacobs, W. A. The aconite alkaloids. XXXI. A partial synthesis of atisine, isoatisine and dihydroatisine. J. Am. Chem. Soc. 1956, 78, 4144. (b) Pelletier, S. W.; Parthasarathy, P. C. The diterpene alkaloids: a partial synthesis of atisine. Tetrahedron Lett. 1963, 4, 205. (c) Nagata, W.; Sugasawa, T.; Narisada, M.; Wakabayashi, T.; Hayase, Y. Stereospecific total synthesis of $d l$-atisine. J. Am. Chem. Soc. 1963, 85, 2342. (d) Masamune, S. Total syntheses of diterpenes and diterpene alkaloids. V. atisine. J. Am. Chem. Soc. 1964, 86, 291. (e) Guthrie, R. W.; Valenta, Z.; Wiesner, K. Synthesis in the series of diterpene alkaloids VI. A simple synthesis of atisine. Tetrahedron Lett. 1966, 7, 4645. (f) Nagata, W.; Sugasawa, T.; Narisada, M.; Wakabayashi, T.; Hayase, Y. Total synthesis of $d l$-atisine. J. Am. Chem. Soc. 1967, 89, 1483. (g) Ihara, M.; Suzuki, M.; Fukumoto, K.; Kametani, T.; Kabuto, C. Stereoselective total synthesis of $( \pm)$-atisine via intramolecular double Michael reaction. J. Am. Chem. Soc. 1988, 110, 1963. (h) Ihara, M.; Suzuki, M.; Fukumoto, K.; Kametani, T.; Kabuto, C. Asymmetric total synthesis of atisine via intramolecular double Michael reaction. J. Am. Chem. Soc. 1990, 112, 1164. (i) Liu, X.Y.; Cheng, H.; Li, X.-H.; Chen, Q.-H.; Xu, L.; Wang, F.-P. Oxidative dearomatization/intramolecular Diels-Alder cycloaddition cascade for the syntheses of $( \pm)$-atisine and $( \pm)$-isoazitine. Org. Biomol. Chem. 2012, 10, 1411. (j) Cherney, E. C.; Lopchuk, J. M.; Green, J. C.; Baran, P. S. A unified approach to ent-atisane diterpenes and related alkaloids: synthesis of (-)-methyl atisenoate, (-)-isoatisine, and the hetidine skeleton. J. Am. Chem. Soc. 2014, 136, 12592. (k) Cheng, H.; Zeng, F.H.; Yang, X.; Meng, Y.-J.; Xu, L.; Wang, F.-P. Collective total syntheses of atisane-type diterpenes and atisine-type diterpenoid alkaloids: $( \pm)$-spiramilactone $\mathrm{B},( \pm)$-spiraminol, $( \pm)$-dihydroajaconine, and $( \pm)$ spiramines $C$ and D. Angew. Chem., Int. Ed. 2016, 55, 392. (l) Li, X.-H.; Zhu, M.; Wang, Z.-X.; Liu, X.-Y.; Song, H.; Zhang, D.; Wang, F.-P.; Qin, Y. Synthesis of atisine, ajaconine, denudatine, and hetidine diterpenoid alkaloids by a bioinspired approach. Angew. Chem., Int. Ed. 2016, 55, 15667. (m) Liu, J.; Ma, D. Total syntheses of azitine and the proposed structure of navirine C. Angew. Chem., Int. Ed. 2018, 57, 6676.

(4) (a) Muratake, H.; Natsume, M. Total synthesis of ( \pm )-nominine, a heptacyclic hetisine-type aconite alkaloid. Angew. Chem., Int. Ed. 2004, 43, 4646. (b) Muratake, H.; Natsume, M. Synthetic study of hetisine-type aconite alkaloids. Part 1: preparation of tetracyclic intermediate containing the $\mathrm{C}_{14}-\mathrm{C}_{2} \mathrm{O}$ bond. Tetrahedron 2006, 62, 7056. (c) Muratake, H.; Natsume, M. Synthetic study of hetisine-type aconite alkaloids. Part 2: preparation of hexacyclic compound lacking the C-ring of the hetisan skeleton. Tetrahedron 2006, 62, 7071. (d) Muratake, H.; Natsume, M.; Nakai, H. Synthetic study of hetisinetype aconite alkaloids. Part 3: total synthesis of $( \pm)$-nominine. Tetrahedron 2006, 62, 7093. (e) Peese, K. M.; Gin, D. Y. Efficient synthetic access to the hetisine $\mathrm{C}_{20} \mathrm{O}$-diterpenoid alkaloids. A concise synthesis of nominine via oxidoisoquinolinium-1,3-dipolar and dienamineDiels-Alder cycloadditions. J. Am. Chem. Soc. 20o6, 128, 8734. (f) Peese, K. M.; Gin, D. Y. Total synthesis of (+)-nominine. Chem. Eur. J. 2008, 14, 1654. (g) Zhang, Q.-Z.; Zhang, Z.-S.; Huang, Z.; Zhang, C.-H.; $\mathrm{Xi}$, S.; Zhang, M. Stereoselective total synthesis of hetisine-type C20diterpenoid alkaloids: spirasine IV and XI. Angew. Chem., Int. Ed. 2018, 57, 937. (h) Kou, K. G. M.; Pflueger, J. J.; Kiho, T.; Morrill, L. C.; Fisher, E. L.; Clagg, K.; Lebold, T. P.; Kisunzu, J. K.; Sarpong, R. A benzyne insertion approach to hetisine-type diterpenoid alkaloids: synthesis of cossonidine (davisine). J. Am. Chem. Soc. 2018, 140, 8105. (5) (a) Nishiyama, Y.; Han-ya, Y.; Yokoshima, S.; Fukuyama, T. Total synthesis of (-)-lepenine. J. Am. Chem. Soc. 2014, 136, 6598. (b) Kou, K. G. M.; Li, B. X.; Lee, J. C.; Gallego, G. M.; Lebold, T. P.; DiPasquale, A. G.; Sarpong, R. Syntheses of denudatine diterpenoid alkaloids: cochlearenine, $\quad N$-ethyl-1 $\alpha$-hydroxy-17-veratroyldictyzine, and paniculamine. J. Am. Chem. Soc. 2016, 138, 10830. (c) Kou, K. G. M.; Kulyk, S.; Marth, C. J.; Lee, J. C.; Doering, N. A.; Li, B. X.; Gallego, G. M.; Lebold, T. P.; Sarpong, R. A unifying synthesis approach to the C18-, C19-, and C20-diterpenoid alkaloids. J. Am. Chem. Soc. 2017, 139, 13882. Also see ref. 3 l.

(6) (a) Masamune, S. Total syntheses of diterpenes and diterpene alkaloids. IV. Garryine. J. Am. Chem. Soc. 1964, 86, 290. (b) Nagata, W.; Narisada, M.; Wakabayashi, T.; Sugasawa, T. Total synthesis of $d l$-garryine and $d l$-veatchine. J. Am. Chem. Soc. 1964, 86, 929. (c) Valenta, Z.; Wiesner, K.; Wong, C. M. Synthesis in the diterpene alkaloid series - II. A total synthesis of the garrya alkaloids. Tetrahedron Lett. 1964, 5, 2437. (d) Nagata, W.; Narisada, M.; Wakabayashi, T.; Sugasawa, T. Total synthesis of $d l$-veatchine and $d l$-garryine. $J$. Am. Chem. Soc. 1967, 89, 1499. (e) Wiesner, K.; Uyeo, S.; Philipp, A.; Valenta, Z. Synthesis in the series of diterpene alkaloids. IX. A new simple synthesis of veatchine. Tetrahedron Lett. 1968, 9, 6279.

(7) (a) Wiesner, K.; Ho, P.; Tsai, C. S. J.; Lam, Y. The Total synthesis of racemic napelline. Can. J. Chem. 1974, 52, 2355. (b) Sethi, S. P.; Atwal, K. S.; Marini-Bettolo, R. M.; Tsai, T. Y. R.; Wiesner, K. A stereospecific synthesis of napelline. Can. J. Chem. 1980, 58, 1889.

(8) For recent synthetic studies, see: (a) Hamlin, A. M.; Cortez, F. J.; Lapointe, D.; Sarpong, R. Gallium(III)-catalyzed cycloisomerization approach to the diterpenoid alkaloids: construction of the core structure for the hetidines and hetisines. Angew. Chem., Int. Ed. 2013, 52, 4854. (b) Hamlin, A. M.; Lapointe, D.; Owens, K.; Sarpong, R. Studies on $\mathrm{C}_{20}$-diterpenoid alkaloids: synthesis of the hetidine framework and its application to the synthesis of dihydronavirine and the atisine skeleton. J. Org. Chem. 2014, 79, 6783. (c) Zhu, M.; Li, X.-H.; Song, X.; Wang, Z.-X.; Liu, X.-Y.; Song, H.; Zhang, D.; Wang, F.-P.; Qin, Y. Studies towards bioinspired synthesis of hetidine-type $\mathrm{C}_{20}-$ diterpenoid alkaloids. Chin. J. Chem. 2017, 35, 991. Also see ref. 3j, l, $\mathrm{m}$.

(9) Zhou, S.; Guo, R.; Yang, P.; Li, A. Total synthesis of septedine and 7-deoxyseptedine. J. Am. Chem. Soc. 2018, 140, 9025.

(10) (a) Tashkhodzhaev, B.; Saidkhodzhaeva, S. A.; Bessonova, I. A.; Antipin, M. Y. Arcutine-a new type of diterpene alkaloids. Chem. Nat. Compd. 20oo, 36, 79. (b) Saidkhodzhaeva, S. A.; Bessonova, I. A.; Abdullaev, N. D. Arcutinine, a new alkaloid from Aconitum arcuatum. Chem. Nat. Compd. 20o1, 37, 466.

(11) Tang, P.; Chen, Q.-H.; Wang, F.-P. Atropurpuran, a novel diterpene with an unprecedented pentacyclic cage skeleton, from Aconitum hemsleyanum var. atropurpureum. Tetrahedron Lett. 2009, 50, 460 .

(12) (a) Suzuki, T.; Sasaki, A.; Egashira, N; Kobayashi, S. A synthetic study of atropurpuran: construction of a pentacyclic framework by an intramolecular reverse-electron-demand Diels-Alder reaction. Angew. Chem. Int. Ed. 2011, 50, 9177. (b) Hayashi, R.; Ma, Z. X.; Hsung, R. P. A tandem 1,3-H-shift-6pelectrocyclization-cyclic 2amido-diene intramolecular Diels-Alder cycloaddition approach to BCD-ring of atropurpuran. Org. Lett. 2012, 14, 252. (c) Chen, H.; Zhang, D.; Xue, F.; Qin, Y. Synthesis of the atropurpuran A-ring via an organocatalytic asymmetric intramolecular Michael addition. Tetrahedron 2013, 69, 3141. (d) Chen, H.; Li, X.-H.; Gong, J.; Song, H.; Liu, X.-Y.; Qin, Y. Synthetic approach to the functionalized tricyclic core of atropurpuran. Tetrahedron 2016, 72, 347. (e) Jarhad, D. B.; Singh, V. $\pi^{4} s+\pi^{2} s$ Cycloaddition of spiroepoxycyclohexa-2,4-dienone, radical cyclization, and oxidation-aldol-oxidation cascade: synthesis of BCDE ring of atropurpuran. J. Org. Chem. 2016, 81, 4304.

(13) Gong, J.; Chen, H.; Liu, X.-Y.; Wang, Z.-X.; Nie, W.; Qin, Y. Total synthesis of atropurpuran. Nat. Comm. 2016, 7, 12183.

(14) Xie, S.; Chen, G.; Yan, H.; Hou, J.; He, Y.; Zhao, T.; Xu, J. 13-Step total synthesis of atropurpuran. J. Am. Chem. Soc. 2019, 141, 3435.

(15) Nie, W.; Gong, J.; Chen, Z.; Liu, J.; Tian, D.; Song, H.; Liu, X.-Y.; Qin, Y. Enantioselective total synthesis of (-)-arcutinine. J. Am. Chem. Soc. doi: 10.1021/jacs.9bo4847. 
(16) Weber, M.; Owens, K.; Sarpong, R. Atropurpuran-missing biosynthetic link leading to the hetidine and arcutine $C_{20}$-diterpenoid alkaloids or an oxidative degradation product? Tetrahedron Lett. 2015, 56, 3600.

(17) (a) Sun, Y.; Li, R.; Zhang, W.; Li, A. Total synthesis of indotertine A and drimentines A, F, and G. Angew. Chem., Int. Ed. 2013, 52, 9201. (b) Sun, Y.; Chen, P.; Zhang, D.; Baunach, M.; Hertweck, C.; Li, A. Bioinspired total synthesis of sespenine. Angew. Chem., Int. Ed. 2014, 53, 9012. (c) Lu, Z.; Yang, M.; Chen, P.; Xiong, X.; Li, A. Total synthesis of hapalindole-type natural products. Angew. Chem., Int. Ed. 2014, 53, 13840. (d) Deng, J.; Zhou, S.; Zhang, W.; Li, J.; Li, R.; Li, A. Total synthesis of taiwaniadducts B, C, and D, J. Am. Chem. Soc. 2014, 136, 8185. (e) Lu, Z.; Li, H.; Bian, M.; Li, A. Total synthesis of epoxyeujindole A. J. Am. Chem. Soc. 2015, 137, 13764. (f) Li, H.; Chen, Q.; Lu, Z.; Li, A. Total syntheses of aflavazole and 14hydroxyaflavinine, J. Am. Chem. Soc. 2016, 138, 15555.

(18) (a) Gahman, T. C.; Overman, L. E. Stereoselective synthesis of carbocyclic ring systems by pinacol-terminated Prins cyclizations. Tetrahedron 2002, 58, 6473. (b) Pennington, L. D.; Overman, L. E. Strategic use of pinacol-terminated Prins cyclizations in targetoriented total synthesis. J. Org. Chem. 2003, 68, 7143. (c) Velthuisen, E.; J.; Overman, L. E. Scope and facial selectivity of the Prins-pinacol synthesis of attached rings. J. Org. Chem. 20o6, 71, 1581.

(19) Sarpong and co-workers reported an elegant synthesis of ( \pm )arcutinidine, as we reported this study.

(20) For recent examples, see: (a) Andrez, J.-C.; Giroux, M.-A.; Lucien, J.; Canesi, S. Rapid formation of hindered cores using an oxidative Prins process. Org. Lett. 2010, 12, 4368. (b) Reddy, B. V. S.; Muralikrishna, K.; Yadav, J. S.; Babu, N. J.; Sirisha, K.; Sarma, A. V. S. Tandem Prins/Wagner/Ritter process for the stereoselective synthesis of (3-oxabicyclo[4.2.o]octanyl)amide and (1-(5aryltetrahydrofuran-3-yl)cyclobutyl)amide derivatives. Org. Biomol. Chem. 2015, 13, 5532.

(21) Carreño, M. C., Urbano, A.; Di Vitta, C. Enantioselective Diels-Alder approach to $\mathrm{C}_{3}$-oxygenated angucyclinones from (SS)-2(p-tolylsulfinyl)-1,4-naphthoquinone. Chem. Eur. J. 2ooo, 6, 906.

(22) For strategically inspiring examples: see: (a) Bergmann, E. D.; Becker, A. Diels-Alder reactions with 1-formylcyclohexene and 1formylcyclopentene. J. Am. Chem. Soc. 1959, 81, 221. (b) Stoltz, B. M.; Kano, T.; Corey, E. J. Enantioselective total synthesis of nicandrenones. J. Am. Chem. Soc. 200o, 122, 9044. (c) Jung, M. E.; Lui, R. M. Studies toward the total syntheses of cucurbitacins B and D. J. Org. Chem. 2010, 75, 7146. (d) Tartakoff, S. S.; Vanderwal, C. D. A synthesis of the $A B C$ tricyclic core of the clionastatins serves to corroborate their proposed structures. Org. Lett. 2014, 16, 1458.

(23) We developed an improved resolution protocol using the Candida antarctica lipase (see the SI). For a relevant example, see: Li, J.; Zhang, W.; Zhang, F.; Chen, Y.; Li, A. Total synthesis of daphniyunnine C (longeracinphyllin A). J. Am. Chem. Soc. 2017, 139, 14893.

(24) Carlsen, P. H. J.; Katsuki, T.; Martin, V. S.; Sharpless, K. B. A greatly improved procedure for ruthenium tetroxide catalyzed oxidations of organic compounds. J. Org. Chem. 1981, 46, 3936. For a recent application by our group, see ref. $17 \mathrm{~d}$.

(25) See, Y. Y.; Herrmann, A. T.; Aihara, Y.; Baran, P. S. Scalable C-H oxidation with copper: synthesis of polyoxypregnanes. J. Am. Chem. Soc. 2015, 137, 13776.

(26) Uenishi, J.; Tatsumi, Y.; Kobayashi, N.; Yonemitsu, O. Highly stereoselective alkylation at neopentyl position on $\beta, \beta$-dialkyl substituted $\gamma$-butyrolactone ring. Tetrahedron Lett. 1995, 36, 5909.

(27) Tomioka, H.; Takai, K.; Oshima, K.; Nozaki, H. Selective oxidation of a primary hydroxyl in the presence of secondary one. Tetrahedron Lett. 1981, 22, 1605.

(28) Leeds, J. P.; Kirst, H. A. A mild single-step reduction of oximes to amines. Synth. Commun. 1988, 18, 777. 
The graphic entry for the TOC

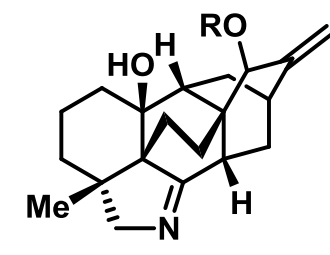

arcutinidine; $\mathbf{R}=\mathbf{H}$

arcutinine; $\mathrm{R}=\boldsymbol{i}$-PrCO 
Asymmetric Total Synthesis of Arcutinidine and Arcutinin... (848.42 KiB) view on ChemRxiv • download file 


\title{
Asymmetric Total Synthesis of Arcutinidine and Arcutinine
}

\author{
Shupeng Zhou, Kaifu Xia, and Ang Li*
}

State Key Laboratory of Bioorganic and Natural Products Chemistry, Center for Excellence in Molecular

Synthesis, Shanghai Institute of Organic Chemistry, University of Chinese Academy of Sciences, Chinese Academy of Sciences, 345 Lingling Road, Shanghai 200032, China

*E-mail: ali@ sioc.ac.cn

I Experimental Procedures and Spectroscopic Data of Compounds

II HPLC Traces for Measuring Enantiomeric Excess

III $\quad{ }^{1} \mathrm{H}$ and ${ }^{13} \mathrm{C}$ NMR Spectra of Compounds

IV References 


\section{Experimental Procedures and Spectroscopic Data of Compounds}

General Procedures. All reactions were carried out under an argon atmosphere with dry solvents under anhydrous conditions, unless otherwise noted. Tetrahydrofuran (THF) was distilled immediately before use from sodium-benzophenoneketyl. Methylene chloride $\left(\mathrm{CH}_{2} \mathrm{Cl}_{2}\right), N, N$-dimethylformamide (DMF), $N, N$-diisopropylaminepyridine $\left(i \mathrm{Pr}_{2} \mathrm{NH}\right)$, hexamethylphosphoramide (HMPA), tert-butanol $(t$-BuOH), triethylamine $\left(\mathrm{Et}_{3} \mathrm{~N}\right)$, and pyridine were distilled from calcium hydride and stored under an argon atmosphere. Methanol $(\mathrm{MeOH})$ and ethanol $(\mathrm{EtOH})$ was distilled from magnesium and stored under an argon atmosphere. Lipase acrylic resin from Candida antarctica was purchased from Sigma-Aldrich. Reagents were purchased at the highest commercial quality and used without further purification, unless otherwise stated. Solvents for chromatography were used as supplied by Adamas-beta ${ }^{\circledR}$. Reactions were monitored by thin layer chromatography (TLC) carried out on S-2 $0.25 \mathrm{~mm}$ Merck silica gel plates (60F-254) using UV light for visualization and aqueous ammonium cerium nitrate/ammonium molybdate or basic aqueous potassium permanganate as developing agent. SiliaFlash ${ }^{\circledR}$ silica gel (P60, particle size $0.040-0.063 \mathrm{~mm}$ ) was used for flash column chromatography. NMR spectra were recorded on a Bruker AV III 400 or an Agilent 500/54/ASP spectrometer. The spectra were calibrated by using residual undeuterated solvents (for ${ }^{1} \mathrm{H} \mathrm{NMR}$ ) and deuterated solvents (for ${ }^{13} \mathrm{C} \mathrm{NMR}$ ) as internal references: undeuterated chloroform $\left(\delta_{\mathrm{H}}=7.26 \mathrm{ppm}\right)$ and $\mathrm{CDCl}_{3}\left(\delta_{\mathrm{C}}=77.16 \mathrm{ppm}\right)$; undeuterated methanol $\left(\delta_{\mathrm{H}}=3.31 \mathrm{ppm}\right)$ and methanol- $\mathrm{d}_{4}\left(\delta_{\mathrm{C}}=49.00 \mathrm{ppm}\right) ;$ undeuterated acetone $\left(\delta_{\mathrm{H}}=2.05 \mathrm{ppm}\right)$ and acetone- $\mathrm{d}_{6}\left(\delta_{\mathrm{C}}=29.84 \mathrm{ppm}\right)$. The following abbreviations are used to designate multiplicities: $\mathrm{s}=$ singlet, $\mathrm{d}=$ doublet, $\mathrm{t}=$ triplet, $\mathrm{q}=$ quartet, $\mathrm{m}=$ multiplet, $\mathrm{br}=$ broad. IR spectra were recorded on a Thermo Scientific Nicolet 380 FT-IR spectrometer. Melting points (m.p.) are uncorrected and were recorded on an SGW X-4 apparatus. High-resolution mass spectra (HRMS) were recorded on a Bruker APEX III 7.0 Tesla ESI-FT mass spectrometer. 


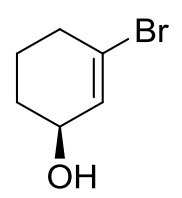

13

Enantioenriched alcohol 13: Racemic alcohol 13 was prepared from commercially available 1,3-cyclohexanedione through a two-step sequence according to the literature. ${ }^{1,2}$ To a stirred solution of racemic $13(40.0 \mathrm{~g}, 226 \mathrm{mmol})$ in $t$-BuOMe $(160 \mathrm{~mL})$ were sequentially added vinyl acetate $(23.4 \mathrm{~g}$, $25.0 \mathrm{~mL}, 272 \mathrm{mmol})$ and lipase acrylic resin from Candida antarctica $(400 \mathrm{mg})$ at $22{ }^{\circ} \mathrm{C} .{ }^{3}$ The resultant mixture was stirred at that temperature for $58 \mathrm{~h}$ before it was filtered and concentrated under vacuum. The residue was purified by flash column chromatography with EtOAc/petroleum ether $(1: 5 \rightarrow 1: 2)$ to give enantioenriched alcohol $13(16.8 \mathrm{~g}, 42 \%, 99.7 \% \mathrm{ee})$ as a pale yellow oil. 13: $[\alpha]_{\mathrm{D}}^{25}=-39.1(\mathrm{c}=1.0$ in $\mathrm{CHCl}_{3}$ ). The ee of $\mathbf{1 3}$ was determined by HPLC (vide infra). The spectra and physical properties of enantioenriched $\mathbf{1 3}$ are identical to those reported in the literature. ${ }^{2}$

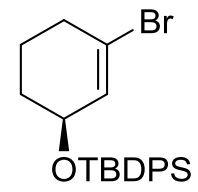

14

Silyl ether 14: To a stirred solution of enantioenriched alcohol 13 (25.6 g, $145 \mathrm{mmol})$ in DMF (30 mL) were sequentially added imidazole $(14.8 \mathrm{~g}, 217 \mathrm{mmol})$ and TBDPSCl $(42.3 \mathrm{~g}, 40.0 \mathrm{~mL}, 154 \mathrm{mmol})$ at $22{ }^{\circ} \mathrm{C}$. The resultant mixture was stirred at that temperature for $8 \mathrm{~h}$ before it was quenched with saturated aq. $\mathrm{NaHCO}_{3}(300 \mathrm{~mL})$. The mixture so obtained was extracted with petroleum ether $(3 \times 400$ $\mathrm{mL})$. The combined organic phases were washed with brine $(300 \mathrm{~mL})$, dried over anhydrous $\mathrm{Na}_{2} \mathrm{SO}_{4}$, filtered, and concentrated under vacuum. The residue was purified by flash column chromatography with EtOAc/petroleum ether (1:100) as eluent to give silyl ether $\mathbf{1 4}(56.2 \mathrm{~g}, 93 \%)$ as a white powder. 14: $R_{\mathrm{f}}=0.27$ (silica, petroleum ether); $[\alpha]_{\mathrm{D}}^{25}=-83.9\left(c=1.0\right.$ in $\left.\mathrm{CHCl}_{3}\right) ; \mathrm{IR}\left(\right.$ film): $v_{\max }=3070,3042,2930$, 2857, 1646, 1427, 1361, 1111, 1022, 972, $701 \mathrm{~cm}^{-1} ;{ }^{1} \mathrm{H}$ NMR $\left(500 \mathrm{MHz}, \mathrm{CDCl}_{3}\right): \delta=7.70-7.63(\mathrm{~m}, 4$ H), 7.51-7.31 (m, $6 \mathrm{H})$, 5.98-5.93 (m, $1 \mathrm{H}), 4.24-4.18(\mathrm{~m}, 1 \mathrm{H}), 2.51-2.38(\mathrm{~m}, 1 \mathrm{H}), 2.36-2.23(\mathrm{~m}, 1$ H), $1.97-1.83(\mathrm{~m}, 1 \mathrm{H}), 1.70-1.60(\mathrm{~m}, 2 \mathrm{H}), 1.59-1.48(\mathrm{~m}, 1 \mathrm{H}), 1.06(\mathrm{~s}, 9 \mathrm{H}) \mathrm{ppm} ;{ }^{13} \mathrm{C}$ NMR (101 
$\left.\mathrm{MHz}, \mathrm{CDCl}_{3}\right): \delta=135.93,135.90,134.2,134.1,132.3,129.83,129.82,127.77,127.75,125.9,68.6$, 35.3, 30.9, 27.1, 20.8, 19.3 ppm; HRMS (m/z): $[\mathrm{M}+\mathrm{Na}]^{+}$calcd for $\mathrm{C}_{22} \mathrm{H}_{27} \mathrm{BrOSiNa}^{+}$437.0907, found 437.0906.

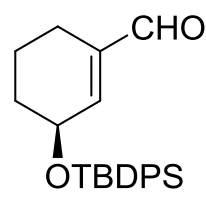

12

Aldehyde 12: To a stirred solution of silyl ether $14(15.8 \mathrm{~g}, 38.0 \mathrm{mmol})$ in THF (200 mL) was added $t$-BuLi $\left(50.0 \mathrm{~mL}, 80.0 \mathrm{mmol}, 1.6 \mathrm{M}\right.$ in pentane) at $-78^{\circ} \mathrm{C}$ and the resultant mixture was stirred at that temperature for $30 \mathrm{~min}$ before DMF $(6.04 \mathrm{~g}, 6.40 \mathrm{~mL}, 82.6 \mathrm{mmol})$ was added. The mixture was warmed to $22{ }^{\circ} \mathrm{C}$ and stired for $30 \mathrm{~min}$ before it was quenched with saturated aq. $\mathrm{NaHCO}_{3}(200 \mathrm{~mL})$ and extracted with EtOAc $(3 \times 300 \mathrm{~mL})$. The combined organic phases were washed with brine $(200 \mathrm{~mL})$, dried over anhydrous $\mathrm{Na}_{2} \mathrm{SO}_{4}$, filtered, and concentrated under vacuum. The residue was purified by flash column chromatography with EtOAc/petroleum ether $(1: 50 \rightarrow 1: 30)$ as eluent to give aldehyde 12 $(12.6 \mathrm{~g}, 91 \%) .12: R_{\mathrm{f}}=0.35$ (silica, EtOAc:petroleum ether $\left.1: 40\right) ;[\alpha]_{\mathrm{D}}^{25}=-97.2\left(c=1.0\right.$ in $\left.\mathrm{CHCl}_{3}\right) ; \mathrm{IR}$ (film): $v_{\max }=3070,3049,2931,2857,2708,1690,1471,1427,1172,1110,1080,701 \mathrm{~cm}^{-1} ;{ }^{1} \mathrm{H}$ NMR (400 MHz, $\left.\mathrm{CDCl}_{3}\right): \delta=9.37-9.34(\mathrm{~m}, 1 \mathrm{H}), 7.73-7.66(\mathrm{~m}, 4 \mathrm{H}), 7.49-7.43(\mathrm{~m}, 2 \mathrm{H}), 7.43-7.37$ (m, $\left.4 \mathrm{H}\right)$, 6.51-6.46(m, $1 \mathrm{H}), 4.48-4.39$ (m, $1 \mathrm{H}), 2.19-2.01(\mathrm{~m}, 2 \mathrm{H}), 1.88-1.74(\mathrm{~m}, 2 \mathrm{H}), 1.74-1.62$ (m, $1 \mathrm{H})$, $1.51-1.36(\mathrm{~m}, 1 \mathrm{H}), 1.08(\mathrm{~s}, 9 \mathrm{H}) \mathrm{ppm} ;{ }^{13} \mathrm{C} \mathrm{NMR}\left(101 \mathrm{MHz}, \mathrm{CDCl}_{3}\right): \delta=194.6,151.4,141.7,135.9$, $133.9,133.8,130.00,129.97,127.9,127.8,67.8,31.9,27.0,21.3,19.3,18.9 \mathrm{ppm} ; \mathrm{HRMS}(\mathrm{m} / \mathrm{z}):[\mathrm{M}+$ $\mathrm{Na}]^{+}$calcd for $\mathrm{C}_{23} \mathrm{H}_{28} \mathrm{O}_{2} \mathrm{SiNa}^{+}$387.1751, found 387.1755.

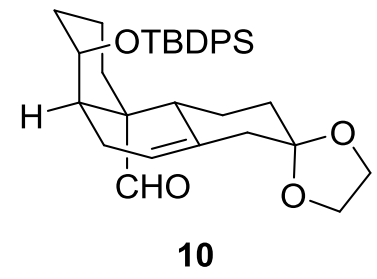

Tricyclic aldehyde 10: To a stirred solution of aldehyde 12 (1.20 g, $3.29 \mathrm{mmol})$ and diene $\mathbf{1 1}^{4}(1.10 \mathrm{~g}$, $6.58 \mathrm{mmol})$ in $\mathrm{CH}_{2} \mathrm{Cl}_{2}(10 \mathrm{~mL})$ was added $\mathrm{BF}_{3} \cdot \mathrm{OEt}_{2}(460 \mathrm{mg}, 400 \mu \mathrm{L}, 3.24 \mathrm{mmol})$ at $-78{ }^{\circ} \mathrm{C}$. The 
resultant mixture was allowed to stir at that temperature for $50 \mathrm{~h}$ before it was quenched with saturated aq. $\mathrm{NaHCO}_{3}(50 \mathrm{~mL})$. The resultant mixture was extracted with EtOAc $(3 \times 100 \mathrm{~mL})$ and the combined organic phases were washed with brine $(50 \mathrm{~mL})$, dried over anhydrous $\mathrm{Na}_{2} \mathrm{SO}_{4}$, and filtered. The solvent was evaporated under vacuum, and the residue was purified by flash column chromatography with $\mathrm{Et}_{2} \mathrm{O} / \mathrm{CH}_{2} \mathrm{Cl}_{2} /$ petroleum ether (3:50:50) to give tricyclic aldehyde $\mathbf{1 0}(1.19 \mathrm{~g}, 68 \%)$ as a white foam. 10: $R_{\mathrm{f}}=0.33$ (silica, $\mathrm{Et}_{2} \mathrm{O} / \mathrm{CH}_{2} \mathrm{Cl}_{2} /$ petroleum ether 3:50:50); $[\alpha]_{\mathrm{D}}^{25}=-109.7\left(c=1.0\right.$ in $\left.\mathrm{CHCl}_{3}\right) ; \mathrm{IR}($ film): $v_{\max }=3069,3047,2930,2856,2698,1722,1427,1375,1261,1106,868,702 \mathrm{~cm}^{-1} ;{ }^{1} \mathrm{H} \mathrm{NMR}(400 \mathrm{MHz}$, $\left.\mathrm{CDCl}_{3}\right): \delta=9.19(\mathrm{~s}, 1 \mathrm{H}), 7.70-7.63(\mathrm{~m}, 4 \mathrm{H}), 7.44-7.34(\mathrm{~m}, 6 \mathrm{H}), 5.50(\mathrm{~d}, J=4.7 \mathrm{~Hz}, 1 \mathrm{H}), 4.06-3.89$ (m, $4 \mathrm{H}), 3.87-3.76(\mathrm{~m}, 1 \mathrm{H}), 2.53-2.40(\mathrm{~m}, 1 \mathrm{H}), 2.40-2.14(\mathrm{~m}, 4 \mathrm{H}), 1.88-1.78$ (m, $1 \mathrm{H}), 1.78-1.69$ (m, $1 \mathrm{H}), 1.61-1.51(\mathrm{~m}, 3 \mathrm{H}), 1.49-1.32(\mathrm{~m}, 4 \mathrm{H}), 1.33-1.24(\mathrm{~m}, 1 \mathrm{H}), 1.05(\mathrm{~s}, 9 \mathrm{H}), 1.02-0.92(\mathrm{~m}, 1 \mathrm{H})$ ppm; ${ }^{13} \mathrm{C}$ NMR (101 MHz, $\left.\mathrm{CD}_{3} \mathrm{COCD}_{3}\right): \delta=207.7,136.5,136.4,135.3,134.72,134.68,130.6,130.5$, $128.5,128.4,119.6,109.2,71.6,64.8,64.7,52.7,46.2,45.5,36.17,35.6,29.5,27.8,27.5,27.4,21.7$, 21.3, 19.8 ppm; HRMS (m/z): $[\mathrm{M}+\mathrm{Na}]^{+}$calcd for $\mathrm{C}_{33} \mathrm{H}_{42} \mathrm{O}_{4} \mathrm{SiNa}^{+}$553.2745, found 553.2746.

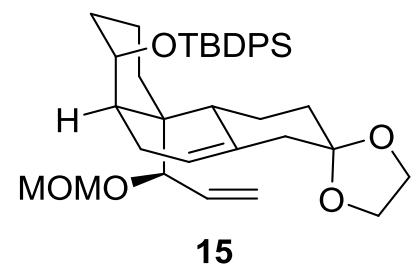

Allylic ether 15: To a stirred solution of tricyclic aldehyde 10 (12.6 g, $23.7 \mathrm{mmol})$ in THF (240 mL) at $-78{ }^{\circ} \mathrm{C}$ was added vinyllithium ${ }^{5}(60.0 \mathrm{~mL}, 0.45 \mathrm{M}$ in THF, $27.0 \mathrm{mmol})$ and the resultant mixture was stirred at that temperature for $30 \mathrm{~min}$ before a solution of $\mathrm{MOMCl}(2.97 \mathrm{~g}, 2.80 \mathrm{~mL}, 36.9 \mathrm{mmol})$ in THF (25 mL) was added. The resultant mixture was warmed to $22{ }^{\circ} \mathrm{C}$ and stirred for 30 min before it was quenched with saturated aq. $\mathrm{NaHCO}_{3}(150 \mathrm{~mL})$. The organic layer was separated, and the aqueous layer was extracted with EtOAc $(3 \times 300 \mathrm{~mL})$. The combined organic phases were washed with brine $(200$ $\mathrm{mL}$ ), dried over anhydrous $\mathrm{Na}_{2} \mathrm{SO}_{4}$, and filtered. The solvent was removed under vacuum, and the residue was purified by flash column chromatography with EtOAc/petroleum ether $(1: 15 \rightarrow 1: 10)$ to give allylic ether $15(12.2 \mathrm{~g}, 85 \%)$ as a white foam. 15: $R_{\mathrm{f}}=0.33$ (silica, EtOAc:petroleum ether 1:8); $[\alpha]$ ${ }_{\mathrm{D}}^{20}=-80.5\left(c=1.0\right.$ in $\left.\mathrm{CHCl}_{3}\right)$; IR (film): $v_{\max }=3070,2929,1471,1425,1260,1104,1032,924,876$, 
$702 \mathrm{~cm}^{-1} ;{ }^{1} \mathrm{H}$ NMR $\left(400 \mathrm{MHz}, \mathrm{CDCl}_{3}\right): \delta=7.71-7.62(\mathrm{~m}, 4 \mathrm{H}), 7.46-7.32(\mathrm{~m}, 6 \mathrm{H}), 5.86(\mathrm{ddd}, J=17.2$, 10.2, $9.2 \mathrm{~Hz}, 1 \mathrm{H}), 5.50-5.37(\mathrm{~m}, 1 \mathrm{H}), 5.24(\mathrm{dd}, J=10.2,1.1 \mathrm{~Hz}, 1 \mathrm{H}), 5.13(\mathrm{dd}, J=17.2,1.1 \mathrm{~Hz}, 1 \mathrm{H})$, $4.34(\mathrm{~d}, J=6.3 \mathrm{~Hz}, 1 \mathrm{H}), 4.22(\mathrm{~d}, J=6.3 \mathrm{~Hz}, 1 \mathrm{H}), 4.20-4.12(\mathrm{~m}, 1 \mathrm{H}), 4.09-3.90(\mathrm{~m}, 5 \mathrm{H}), 3.10(\mathrm{~s}, 3$ H), 2.65 (br s, $1 \mathrm{H}), 2.53-2.38(\mathrm{~m}, 1 \mathrm{H}), 2.32(\mathrm{dd}, J=12.5,2.5 \mathrm{~Hz}, 1 \mathrm{H}), 2.29-2.13(\mathrm{~m}, 3 \mathrm{H}), 1.87$ (dd, $J$ $=13.1,2.5 \mathrm{~Hz}, 1 \mathrm{H}), 1.70-1.54(\mathrm{~m}, 1 \mathrm{H}), 1.58(\mathrm{dd}, J=13.1,3.8 \mathrm{~Hz}, 1 \mathrm{H}), 1.53-1.24(\mathrm{~m}, 6 \mathrm{H}), 1.03$ (s, 9 $\mathrm{H}), 0.98-0.89(\mathrm{~m}, 1 \mathrm{H}) \mathrm{ppm} ;{ }^{13} \mathrm{C} \mathrm{NMR}\left(101 \mathrm{MHz}, \mathrm{CDCl}_{3}\right): \delta=135.9,135.4,135.3,135.2,134.6$, $129.53,129.49,127.53,127.47,119.7,118.5,109.6,95.8,81.0,69.5,64.6,64.4,56.0,46.4,42.7,36.3$, 33.7, 28.9, 28.2, 27.3, 27.1, 22.4, 19.5, 19.3 ppm; HRMS $(\mathrm{m} / \mathrm{z}):[\mathrm{M}+\mathrm{Na}]^{+}$calcd for $\mathrm{C}_{37} \mathrm{H}_{50} \mathrm{O}_{5} \mathrm{SiNa}^{+}$ 625.3320, found 625.3325 .

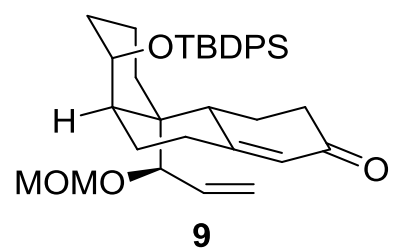

$\boldsymbol{\alpha}, \boldsymbol{\beta}$-Unsaturated enone 9: To a stirred solution of allylic ether 15 (4.65 g, $7.71 \mathrm{mmol})$ in THF/acetone (60 mL, 5:1) was added aq. $\mathrm{HClO}_{4}(20.0 \mathrm{~mL}, 3.0 \mathrm{M})$ at $22{ }^{\circ} \mathrm{C}$. The resultant mixture was allowed to stir at that temperature for $1.5 \mathrm{~h}$ before it was quenched with saturated aq. $\mathrm{NaHCO}_{3}(100 \mathrm{~mL})$. The mixture so obtained was extracted with EtOAc $(3 \times 200 \mathrm{~mL})$. The combined organic phases were washed with brine $(100 \mathrm{~mL})$, dried over anhydrous $\mathrm{Na}_{2} \mathrm{SO}_{4}$, filtered, and concentrated under vacuum. The residue was subjected to flash column chromatography for purification using EtOAc/petroleum ether $(1: 10 \rightarrow$ 1:5) as eluent to give $\alpha, \beta$-unsaturated enone $9(3.10 \mathrm{~g}, 72 \%)$ as a white foam. 9: $R_{\mathrm{f}}=0.36$ (silica, EtOAc:petroleum ether 1:3); $[\alpha]_{\mathrm{D}}^{20}=-40.5\left(c=1.0\right.$ in $\left.\mathrm{CHCl}_{3}\right)$; IR (film): $v_{\max }=3071,3047,2932,2888$, 2822, 1669, 1609, 1471, 1426, 1256, 1105, 996, $756 \mathrm{~cm}^{-1} ;{ }^{1} \mathrm{H}$ NMR $\left(400 \mathrm{MHz}, \mathrm{CDCl}_{3}\right): \delta=7.71-7.60$ (m, 4 H), 7.47-7.39 (m, 2 H), 7.38-7.32 (m, 4 H), 5.95 (s, 1 H), 5.63 (ddd, J = 17.2, 10.3, 8.5 Hz, 1 H), $5.23(\mathrm{dd}, J=10.3,1.4 \mathrm{~Hz}, 1 \mathrm{H}), 5.16(\mathrm{~d}, J=17.2 \mathrm{~Hz}, 1 \mathrm{H}), 4.53(\mathrm{~d}, J=6.6 \mathrm{~Hz}, 1 \mathrm{H}), 4.33(\mathrm{~d}, J=6.6 \mathrm{~Hz}$, $1 \mathrm{H}), 4.30-4.23(\mathrm{~m}, 1 \mathrm{H}), 3.90(\mathrm{~d}, J=8.5 \mathrm{~Hz}, 1 \mathrm{H}), 3.72-3.53(\mathrm{~m}, 1 \mathrm{H}), 3.24(\mathrm{~s}, 3 \mathrm{H}), 3.02-2.87(\mathrm{~m}, 1$ H), 2.56-2.45 (m, 1 H), 2.41-2.20 (m, 3 H), 2.17-2.07 (m, $1 \mathrm{H}), 2.00-1.85(\mathrm{~m}, 2 \mathrm{H}), 1.84-1.70$ (m, 1 H), $1.69-1.55$ (m, $2 \mathrm{H}), 1.46-1.22(\mathrm{~m}, 4 \mathrm{H}), 1.05$ (s, $9 \mathrm{H}) \mathrm{ppm} ;{ }^{13} \mathrm{C} \mathrm{NMR}\left(101 \mathrm{MHz}, \mathrm{CDCl}_{3}\right): \delta=199.8$, 
$169.2,136.0,135.9,134.5,133.9,133.2,129.75,129.68,127.57,127.54,126.4,119.9,93.8,81.68,74.4$, 56.7, 43.7, 41.0, 40.4, 38.1, 31.9, 31.7, 27.3, 26.8, 22.5, 22.1, 19.5, 15.8 ppm; HRMS (m/z): [M + Na $]^{+}$ calcd for $\mathrm{C}_{35} \mathrm{H}_{46} \mathrm{O}_{4} \mathrm{SiNa}^{+} 581.3058$, found 581.3060.

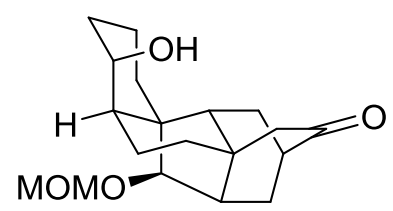

16

Cycloadduct 16: A solution of $\alpha, \beta$-unsaturated enone $9(9.10 \mathrm{~g}, 16.3 \mathrm{mmol})$ in THF (160 mL) was subjected to the freeze-pump-thaw cycling for three times. To the solution was added LiHMDS (50.0 $\mathrm{mL}, 1.0 \mathrm{M}$ in THF, $50.0 \mathrm{mmol})$ at $22{ }^{\circ} \mathrm{C}$. The reaction mixture was allowed to stir at that temperature for $7 \mathrm{~h}$ before TBAF $(80.0 \mathrm{~mL}, 1.0 \mathrm{M}$ in THF, $80.0 \mathrm{mmol})$ was added. The resultant mixture was heated to $70{ }^{\circ} \mathrm{C}$ and stirred at that temperature for $5 \mathrm{~h}$ before it was quenched with saturated aq. $\mathrm{NH}_{4} \mathrm{Cl}(200 \mathrm{~mL})$. The resultant mixture was extracted with EtOAc $(3 \times 300 \mathrm{~mL})$ and the combined organic phases were washed with brine $(200 \mathrm{~mL})$, dried over anhydrous $\mathrm{Na}_{2} \mathrm{SO}_{4}$, and filtered. The solvent was evaporated under vacuum, and the residue was purified by flash column chromatography with EtOAc/petroleum ether $(1: 5 \rightarrow 1: 2)$ to give cycloadduct $16(4.38 \mathrm{~g}, 84 \%)$ as a white solid. 16: $R_{\mathrm{f}}=0.30$ (silica, EtOAc:petroleum ether 1:2); $[\alpha]_{\mathrm{D}}^{20}=-52.0\left(c=1.0\right.$ in $\left.\mathrm{CHCl}_{3}\right)$; IR (film): $v_{\max }=3485,2927,1714,1461$, 1393, 1334, 1238, 1123, 1042, 922, $757 \mathrm{~cm}^{-1} ;{ }^{1} \mathrm{H}$ NMR $\left(500 \mathrm{MHz}, \mathrm{CDCl}_{3}\right): \delta=4.73(\mathrm{~d}, J=6.6 \mathrm{~Hz}, 1$ H), $4.63(\mathrm{~d}, J=6.6 \mathrm{~Hz}, 1 \mathrm{H}), 4.08(\mathrm{~s}, 1 \mathrm{H}), 3.46(\mathrm{~s}, 1 \mathrm{H}), 3.38(\mathrm{~s}, 3 \mathrm{H}), 2.70-2.62(\mathrm{~m}, 1 \mathrm{H}), 2.30(\mathrm{~d}, J=$ $19.6 \mathrm{~Hz}, 1 \mathrm{H}), 2.23-2.19(\mathrm{~m}, 1 \mathrm{H}), 2.18-2.10(\mathrm{~m}, 1 \mathrm{H}), 2.12(\mathrm{~d}, J=19.6 \mathrm{~Hz}, 1 \mathrm{H}), 2.08-2.01(\mathrm{~m}, 1 \mathrm{H})$, 1.94-1.89 (m, $1 \mathrm{H}), 1.89-1.82(\mathrm{~m}, 3 \mathrm{H}), 1.82-1.78(\mathrm{~m}, 1 \mathrm{H}), 1.78-1.70(\mathrm{~m}, 2 \mathrm{H}), 1.70-1.62(\mathrm{~m}, 1 \mathrm{H})$, $1.61-1.52(\mathrm{~m}, 1 \mathrm{H}), 1.52-1.41(\mathrm{~m}, 3 \mathrm{H}), 1.34-1.23(\mathrm{~m}, 2 \mathrm{H}) \mathrm{ppm} ;{ }^{13} \mathrm{C} \mathrm{NMR}\left(126 \mathrm{MHz}, \mathrm{CDCl}_{3}\right): \delta=$ 216.7, 96.9, 95.1, 74.6, 55.5, 46.7, 44.7, 44.1, 43.2, 42.0, 40.8, 39.2, 35.3, 35.1, 34.2, 31.9, 25.4, 24.9, 18.4 ppm; HRMS (m/z): $[\mathrm{M}+\mathrm{Na}]^{+}$calcd for $\mathrm{C}_{19} \mathrm{H}_{28} \mathrm{O}_{4} \mathrm{Na}^{+}$343.1880, found 343.1884. CCDC 1914278 contains the supplementary crystallographic data of $\mathbf{1 6}$ [m.p.: 112-115 ${ }^{\circ} \mathrm{C}$ (EtOAc:petroleum ether 1:10)]. These data can be obtained free of charge from The Cambridge Crystallographic Data Centre via www.ccdc.cam.ac.uk/data_request/cif. 


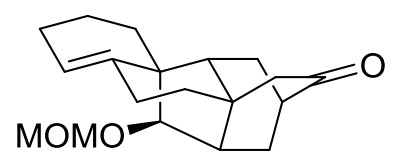

8

Pentacyclic intermediate 8: To a stirred solution of cycloadduct 16 (3.80 g, $11.9 \mathrm{mmol})$ in $\mathrm{CH}_{2} \mathrm{Cl}_{2}$ $(400 \mathrm{~mL})$ were sequentially added pyridine $(48.9 \mathrm{~g}, 50.0 \mathrm{~mL}, 618 \mathrm{mmol})$ and $\mathrm{SOCl}_{2}(7.22 \mathrm{~g}, 4.40 \mathrm{~mL}$, $60.6 \mathrm{mmol}$ ) at $0{ }^{\circ} \mathrm{C}$. The resultant mixture was allowed to stir at that temperature for $1 \mathrm{~h}$ before it was quenched with saturated aq. $\mathrm{NaHCO}_{3}(200 \mathrm{~mL})$. The organic layer was separated, and the aqueous layer was extracted with $\mathrm{CH}_{2} \mathrm{Cl}_{2}(3 \times 300 \mathrm{~mL})$. The combined organic phases were sequentially washed with aq. citric acid $(4 \times 200 \mathrm{~mL}, 10 \mathrm{wt} \%)$ and brine $(200 \mathrm{~mL})$, dried over anhydrous $\mathrm{Na}_{2} \mathrm{SO}_{4}$, and filtered. The solvent was evaporated under vacuum. The residue was subjected to flash column chromatography for purification using EtOAc/petroleum ether $(1: 10 \rightarrow 1: 5)$ as eluent to give pentacyclic intermediate 8 $(2.73 \mathrm{~g}, 76 \%)$ as a white foam. 8: $R_{\mathrm{f}}=0.31$ (silica, EtOAc:petroleum ether 1:4); $[\alpha]_{\mathrm{D}}^{20}=-156.9(c=1.0$ in $\mathrm{CHCl}_{3}$ ); IR (film): $v_{\max }=2927,1730,1453,1398,1327,1288,1128,1105,1030,960,861,799 \mathrm{~cm}^{-1}$; ${ }^{1} \mathrm{H}$ NMR $\left(500 \mathrm{MHz}, \mathrm{CDCl}_{3}\right): \delta=5.57-5.51(\mathrm{~m}, 1 \mathrm{H}), 4.76(\mathrm{~d}, J=6.8 \mathrm{~Hz}, 1 \mathrm{H}), 4.66(\mathrm{~d}, J=6.8 \mathrm{~Hz}, 1 \mathrm{H})$, 3.63-3.58 (m, $1 \mathrm{H}), 3.39(\mathrm{~s}, 3 \mathrm{H}), 2.78-2.68(\mathrm{~m}, 1 \mathrm{H}), 2.33$ (d, J = 19.6 Hz, $1 \mathrm{H}), 2.29-2.24(\mathrm{~m}, 1 \mathrm{H})$, $2.12(\mathrm{~d}, J=19.6 \mathrm{~Hz}, 1 \mathrm{H}), 2.15-2.02(\mathrm{~m}, 2 \mathrm{H}), 2.02-1.91(\mathrm{~m}, 5 \mathrm{H}), 1.90-1.84(\mathrm{~m}, 1 \mathrm{H}), 1.84-1.75(\mathrm{~m}, 2$ $\mathrm{H}), 1.70-1.60(\mathrm{~m}, 3 \mathrm{H}), 1.54-1.44(\mathrm{~m}, 2 \mathrm{H}) \mathrm{ppm} ;{ }^{13} \mathrm{C} \mathrm{NMR}\left(126 \mathrm{MHz}, \mathrm{CDCl}_{3}\right): \delta=215.6,140.8,121.6$ 97.1, 95.9, 55.7, 48.8, 48.1, 44.4, 44.2, 44.1, 41.9, 37.9, 34.3, 30.6, 28.9, 25.7, 25.5, 20.9 ppm; HRMS $(\mathrm{m} / \mathrm{z}):[\mathrm{M}+\mathrm{Na}]^{+}$calcd for $\mathrm{C}_{19} \mathrm{H}_{26} \mathrm{O}_{3} \mathrm{Na}^{+} 325.1774$, found 325.1779 .

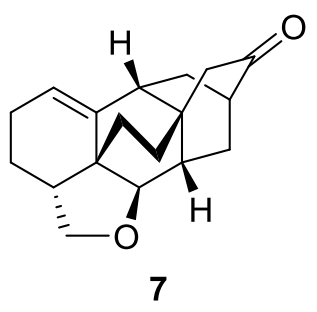

Hexacyclic intermediate 7: To a stirred solution of pentacyclic intermediate 8 (2.57 $\mathrm{g}, 8.50 \mathrm{mmol})$ in $\mathrm{CH}_{2} \mathrm{Cl}_{2}(100 \mathrm{~mL})$ was added $\mathrm{SnCl}_{4}\left(9.00 \mathrm{~mL}, 1.0 \mathrm{M}\right.$ in $\left.\mathrm{CH}_{2} \mathrm{Cl}_{2}, 9.00 \mathrm{mmol}\right)$ at $-15^{\circ} \mathrm{C}$. The mixture was allowed to stir at that temperature for $1 \mathrm{~h}$ before it was quenched with saturated aq. $\mathrm{NH}_{4} \mathrm{Cl}(100 \mathrm{~mL})$ 
and extracted with EtOAc $(3 \times 200 \mathrm{~mL})$. The combined organic phases were washed with brine $(100$ $\mathrm{mL}$ ), dried over anhydrous $\mathrm{Na}_{2} \mathrm{SO}_{4}$, filtered, and concentrated under vacuum. The residue was subjected to flash column chromatography for purification using EtOAc/petroleum ether $(1: 10 \rightarrow 1: 5)$ as eluent to give hexacyclic intermediate $7(1.45 \mathrm{~g}, 63 \%)$ as a white foam. 7: $R_{\mathrm{f}}=0.33$ (silica, EtOAc:petroleum ether 1:3); $[\alpha]_{\mathrm{D}}^{20}=-69.2\left(c=1.0\right.$ in $\left.\mathrm{CHCl}_{3}\right)$; IR (film): $v_{\max }=2930,2858,1729,1460,1460,1400,1259$, 1153, 1043, 960, $806 \mathrm{~cm}^{-1} ;{ }^{1} \mathrm{H}$ NMR $\left(400 \mathrm{MHz}, \mathrm{CDCl}_{3}\right): \delta=5.59-5.51(\mathrm{~m}, 1 \mathrm{H}), 4.30(\mathrm{dd}, J=9.1,7.8 \mathrm{~Hz}$, $1 \mathrm{H}), 3.61-3.51(\mathrm{~m}, 1 \mathrm{H}), 3.44(\mathrm{dd}, J=9.1,4.4 \mathrm{~Hz}, 1 \mathrm{H}), 2.38-2.11(\mathrm{~m}, 4 \mathrm{H}), 2.20(\mathrm{~d}, J=18.8 \mathrm{~Hz}, 1 \mathrm{H})$, $2.01(\mathrm{~d}, J=18.8 \mathrm{~Hz}, 1 \mathrm{H}), 1.97-1.91(\mathrm{~m}, 2 \mathrm{H}), 1.89-1.79(\mathrm{~m}, 3 \mathrm{H}), 1.79-1.67$ (m, $2 \mathrm{H}), 1.57-1.45(\mathrm{~m}, 2 \mathrm{H})$, $1.42-1.31(\mathrm{~m}, 1 \mathrm{H}), 1.31-1.18(\mathrm{~m}, 1 \mathrm{H}), 1.18-1.05(\mathrm{~m}, 1 \mathrm{H}) \mathrm{ppm} ;{ }^{13} \mathrm{C} \mathrm{NMR}\left(126 \mathrm{MHz}, \mathrm{CDCl}_{3}\right): \delta=216.1$, $146.3,119.8,89.9,74.9,47.2,45.8,43.8,40.1,39.7,37.6,36.4,34.9,32.9,30.9,28.1,26.6,24.3$ ppm; HRMS $(m / z):[\mathrm{M}+\mathrm{Na}]^{+}$calcd for $\mathrm{C}_{18} \mathrm{H}_{22} \mathrm{O}_{2} \mathrm{Na}^{+} 293.1512$, found 293.1519 .

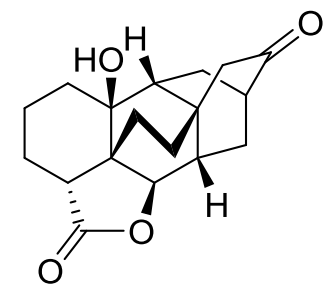

19

Hexacyclic lactone 19: To a stirred solution of hexacyclic intermediate 7 (2.26 g, $8.36 \mathrm{mmol})$ and $\mathrm{PhSiH}_{3}(8.77 \mathrm{~g}, 10.0 \mathrm{~mL}, 81.1 \mathrm{mmol})$ in $\mathrm{EtOH}(70 \mathrm{~mL})$ was added $\mathrm{Mn}(\mathrm{acac})_{2}(212 \mathrm{mg}, 0.837 \mathrm{mmol})$ at $22{ }^{\circ} \mathrm{C}$, through the suspension was bubbled $\mathrm{O}_{2}$ for $30 \mathrm{~min}$. The resultant mixture was allowed to stir under an oxygen atmosphere at $22{ }^{\circ} \mathrm{C}$ for $2 \mathrm{~h}$. The volatiles were removed under vacuum, and the residue was purified by flash column chromatography with EtOAc/petroleum ether $(1: 2 \rightarrow 1: 1)$ to give the tertiary alcohol $(1.95 \mathrm{~g}, 81 \%)$ as a pale yellow oil. This oil was dissolved in acetonitrile/EtOAc (40 $\mathrm{mL}, 1: 1)$. To the stirred solution were sequentially added phosphate buffer (30 mL, $1.0 \mathrm{M}, \mathrm{pH}=7.0$ ), $\mathrm{NaIO}_{4}(7.23 \mathrm{~g}, 33.8 \mathrm{mmol})$, and $\mathrm{RuCl}_{3} \cdot 3 \mathrm{H}_{2} \mathrm{O}(88.4 \mathrm{mg}, 0.338 \mathrm{mmol})$ at $22^{\circ} \mathrm{C}$. The reaction mixture was stirred at that temperature for $24 \mathrm{~h}$ before it was quenched with saturated aq. $\mathrm{NaHCO}_{3}(50 \mathrm{~mL})$ and $\mathrm{Na}_{2} \mathrm{~S}_{2} \mathrm{O}_{3}(50 \mathrm{~mL})$ and extracted with $\mathrm{CH}_{2} \mathrm{Cl}_{2}(3 \times 200 \mathrm{~mL})$. The combined organic phases were washed with brine $(100 \mathrm{~mL})$, dried over anhydrous $\mathrm{Na}_{2} \mathrm{SO}_{4}$, filtered, and concentrated under vacuum. The 
residue was subjected to flash column chromatography for purification using EtOAc/petroleum ether (1:1) as eluent to give lactone $19(1.43 \mathrm{~g}, 70 \%)$ as a white powder. 19: $R_{\mathrm{f}}=0.34$ (silica, EtOAc:petroleum ether 1:2); $[\alpha]_{\mathrm{D}}^{25}=-82.7\left(c=1.0\right.$ in $\left.\mathrm{CHCl}_{3}\right)$; IR (film): $v_{\max }=3473,2928,2867,1747$, $1727,1456,1330,1261,1092,1019,798 \mathrm{~cm}^{-1} ;{ }^{1} \mathrm{H}$ NMR $\left(400 \mathrm{MHz}, \mathrm{CDCl}_{3}\right): \delta=4.32(\mathrm{dd}, J=5.7,1.3$ Hz, $1 \mathrm{H}), 2.38-2.34(\mathrm{~m}, 1 \mathrm{H}), 2.34-2.18(\mathrm{~m}, 2 \mathrm{H}), 2.26(\mathrm{~d}, J=19.3 \mathrm{~Hz}, 1 \mathrm{H}), 2.06(\mathrm{~d}, J=19.3 \mathrm{~Hz}, 1 \mathrm{H})$, 2.11-1.92 (m, $4 \mathrm{H}), 1.89-1.81$ (m, $2 \mathrm{H}), 1.80-1.67$ (m, $3 \mathrm{H}), 1.64-1.52$ (m, $3 \mathrm{H}), 1.51-1.43$ (m, $3 \mathrm{H})$, 1.42-1.33 (m, $1 \mathrm{H}) . \mathrm{ppm} ;{ }^{13} \mathrm{C} \mathrm{NMR}\left(126 \mathrm{MHz}, \mathrm{CDCl}_{3}\right): \delta=214.9,179.1,86.1,72.3,49.0,47.0,45.4$, 44.9, 42.8, 36.9, 34.8, 32.2, 31.7, 29.1, 27.2, 23.6, 22.7, 19.2 ppm; HRMS $(\mathrm{m} / z):[\mathrm{M}+\mathrm{Na}]^{+}$calcd for $\mathrm{C}_{18} \mathrm{H}_{22} \mathrm{O}_{4} \mathrm{Na}^{+}$325.1410, found 325.1412. CCDC 1914280 contains the supplementary crystallographic data of 19 [m.p.: $262-264{ }^{\circ} \mathrm{C}\left(\mathrm{CHCl}_{3}\right.$ :petroleum ether 1:5)]. These data can be obtained free of charge from The Cambridge Crystallographic Data Centre via www.ccdc.cam.ac.uk/data_request/cif.

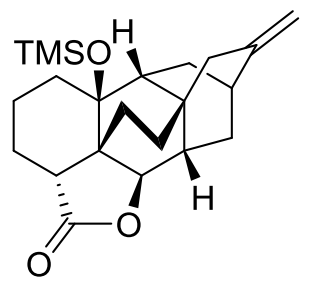

20

Silyl ether 20: To a stirred suspension of methyltriphenylphosphonium bromide $(2.90 \mathrm{~g}, 8.12 \mathrm{mmol})$ in THF $(20 \mathrm{~mL})$ was added $t$-BuOK $(8.00 \mathrm{~mL}, 1.0 \mathrm{M}$ in THF, $8.00 \mathrm{mmol})$ at $22{ }^{\circ} \mathrm{C}$. The mixture was stirred at that temperature for $15 \mathrm{~min}$ before the solution of hexacyclic lactone $19(1.17 \mathrm{~g}, 3.87 \mathrm{mmol})$ in THF (10 mL) was added. The resultant mixture was allowed to stir at $22{ }^{\circ} \mathrm{C}$ for 30 min before it was cooled to $0{ }^{\circ} \mathrm{C}$. $\mathrm{Et}_{3} \mathrm{~N}(3.92 \mathrm{~g}, 5.40 \mathrm{~mL}, 38.7 \mathrm{mmol})$ and TMSOTf $(6.89 \mathrm{~g}, 5.60 \mathrm{~mL}, 31.0 \mathrm{mmol})$ were sequentially added, and the resultant mixture was allowed to stir at that temperature for 15 min before it was quenched with saturated aq. $\mathrm{NaHCO}_{3}(100 \mathrm{~mL})$. The resultant mixture was extracted with EtOAc $(3$ $\times 200 \mathrm{~mL}$ ), and the combined organic phases were washed with brine $(100 \mathrm{~mL})$, dried over anhydrous $\mathrm{Na}_{2} \mathrm{SO}_{4}$, filtered, and concentrated under vacuum. The residue was subjected to flash column chromatography for purification using EtOAc/petroleum ether $(1: 30 \rightarrow 1: 20)$ as eluent to give silyl ether $20(1.23 \mathrm{~g}, 85 \%)$ as a white foam. 20: $R_{\mathrm{f}}=0.31$ (silica, EtOAc:petroleum ether $\left.1: 10\right) ;[\alpha]_{\mathrm{D}}^{25}=-82.4(c=$ 
1.0 in $\mathrm{CHCl}_{3}$ ); IR (film): $v_{\max }=3070,2982,2946,2867,1773,1454,1260,1249,1137,1025,835,753$

$\mathrm{cm}^{-1} ;{ }^{1} \mathrm{H}$ NMR $\left(500 \mathrm{MHz}, \mathrm{CDCl}_{3}\right): \delta=4.75-4.70(\mathrm{~m}, 1 \mathrm{H}), 4.61-4.56(\mathrm{~m}, 1 \mathrm{H}), 4.22(\mathrm{~d}, J=5.6 \mathrm{~Hz}, 1$

H), 2.32-2.27 (m, $1 \mathrm{H}), 2.25-2.15(\mathrm{~m}, 2 \mathrm{H}), 2.08-2.02(\mathrm{~s}, 1 \mathrm{H}), 2.02-1.95(\mathrm{~m}, 2 \mathrm{H}), 1.94-1.85$ (m, $1 \mathrm{H})$, 1.84-1.70 (m, 2 H), 1.69-1.63 (m, 3 H), 1.63-1.54 (m, 4 H), 1.54-1.49 (m, $1 \mathrm{H}), 1.39-1.28$ (m, 3 H), 0.14 (s, $9 \mathrm{H}) \mathrm{ppm} ;{ }^{13} \mathrm{C} \mathrm{NMR}\left(126 \mathrm{MHz}, \mathrm{CDCl}_{3}\right): \delta=179.8,150.6,104.8,87.0,76.2,48.3,46.9,45.3$, 39.3, 36.4, 36.1, 34.9, 34.6, 31.3, 30.9, 29.6, 23.9, 23.5, 19.6, 2.6 ppm; HRMS (m/z): $[\mathrm{M}+\mathrm{H}]^{+}$calcd for $\mathrm{C}_{22} \mathrm{H}_{33} \mathrm{O}_{3} \mathrm{Si}^{+}$373.2193, found 373.2195.

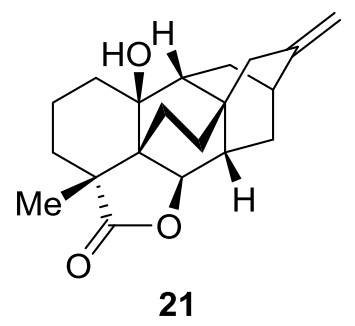

Methylated lactone 21: To a stirred solution of $i-\operatorname{Pr}_{2} \mathrm{NH}(1.52 \mathrm{~g}, 2.10 \mathrm{~mL}, 15.0 \mathrm{mmol})$ in THF (20 mL) was added $\mathrm{BuLi}(6.80 \mathrm{~mL}, 2.13 \mathrm{M}$ in hexane, $14.5 \mathrm{mmol})$ at $0{ }^{\circ} \mathrm{C}$. The mixture was stirred at that temperature for $30 \mathrm{~min}$ before HMPA $(10.0 \mathrm{~mL})$ and a solution of lactone $\mathbf{2 0}(1.78 \mathrm{~g}, 4.78 \mathrm{mmol})$ in THF (10 mL) were sequentially added. The resultant mixture was allowed to stir at $0{ }^{\circ} \mathrm{C}$ for $2 \mathrm{~h}$ before TBAF (50.0 mL, 1.0 M in THF, $50.0 \mathrm{mmol})$ was added. The mixture was warmed to $22{ }^{\circ} \mathrm{C}$ and allowed to stir at that temperature for $3 \mathrm{~h}$ before it was quenched with saturated aq. $\mathrm{NaHCO}_{3}(100 \mathrm{~mL})$. The resultant mixture was extracted with EtOAc $(3 \times 200 \mathrm{~mL})$. The combined organic phases were washed with brine $(100 \mathrm{~mL})$, dried over anhydrous $\mathrm{Na}_{2} \mathrm{SO}_{4}$, filtered, and concentrated under vacuum. The residue was purified by flash column chromatography with EtOAc/petroleum ether $(1: 10 \rightarrow 1: 5)$ to give methylated lactone $21(1.10 \mathrm{~g}, 73 \%)$ as a white powder. 21: $R_{\mathrm{f}}=0.38$ (silica, EtOAc:petroleum ether $1: 3) ;[\alpha]_{\mathrm{D}}^{25}=-100.6\left(c=1.0\right.$ in $\left.\mathrm{CHCl}_{3}\right)$; IR (film): $v_{\max }=3504,3066,2930,2864,1753,1655,1463$, 1379, 1260, 1100, 923, 872, $667 \mathrm{~cm}^{-1} ;{ }^{1} \mathrm{H}$ NMR (500 MHz, $\left.\mathrm{CDCl}_{3}\right): \delta=4.74-4.69(\mathrm{~m}, 1 \mathrm{H}), 4.60-4.54$ (m, $1 \mathrm{H}), 4.18(\mathrm{dd}, J=5.8,1.2 \mathrm{~Hz}, 1 \mathrm{H}), 2.34-2.27(\mathrm{~m}, 1 \mathrm{H}), 2.24-2.16(\mathrm{~m}, 1 \mathrm{H}), 2.14-2.06(\mathrm{~m}, 2 \mathrm{H})$, 2.05-1.98 (m, $1 \mathrm{H}), 1.91-1.77$ (m, $2 \mathrm{H}), 1.76-1.68(\mathrm{~m}, 2 \mathrm{H}), 1.68-1.55$ (m, $6 \mathrm{H}), 1.51-1.43$ (m, $1 \mathrm{H})$, 1.44-1.34 (m, $2 \mathrm{H}), 1.20(\mathrm{~s}, 3 \mathrm{H}), 1.27-1.13(\mathrm{~m}, 2 \mathrm{H}) \mathrm{ppm} ;{ }^{13} \mathrm{C} \mathrm{NMR}\left(126 \mathrm{MHz}, \mathrm{CDCl}_{3}\right): \delta=182.14$, 
$150.60,104.65,85.43,73.64,50.34,48.32,44.95,39.02,36.47,35.94,34.62,34.11,32.59,31.86,31.37$, 29.67, 19.13, 18.67, 16.96 ppm; HRMS $(m / z):[\mathrm{M}+\mathrm{H}]^{+}$calcd for $\mathrm{C}_{20} \mathrm{H}_{27} \mathrm{O}_{3}{ }^{+} 315.1955$, found 315.1959.

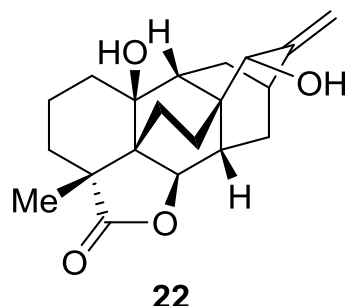

Allylic alcohol 22: To a stirred solution of methylated lactone 21 (1.45 g, $4.61 \mathrm{mmol})$ in $\mathrm{CH}_{2} \mathrm{Cl}_{2}(40 \mathrm{~mL})$ were sequentially added $\mathrm{SeO}_{2}(5.11 \mathrm{~g}, 4.60 \mathrm{mmol})$ and TBHP (4.00 mL, 5.5 $\mathrm{M}$ in decane, $\left.22.0 \mathrm{mmol}\right)$ at $0{ }^{\circ} \mathrm{C}$. The mixture was stirred at that temperature for $3 \mathrm{~h}$ before it was quenched with saturated aq. $\mathrm{Na}_{2} \mathrm{SO}_{3}$ $(100 \mathrm{~mL})$. The organic layer was separated, and the aqueous layer was extracted with EtOAc $(3 \times 100$ $\mathrm{mL})$. The combined organic phases were washed with brine $(50 \mathrm{~mL})$, dried over anhydrous $\mathrm{Na}_{2} \mathrm{SO}_{4}$, and filtered. The volatiles were removed under vacuum, and the residue was purified by flash column chromatography with EtOAc/petroleum ether $(1: 2 \rightarrow 1: 1)$ to give allylic alcohol $22(1.23 \mathrm{~g}, 81 \%)$ as a white foam. 22: $R_{\mathrm{f}}=0.37$ (silica, EtOAc:petroleum ether $\left.1: 1\right) ;[\alpha]_{\mathrm{D}}^{25}=-89.8(c=1.0$ in acetone); IR (film): $v_{\max }=3401,2970,2943,2864,1759,1689,1445,1302,1047,1029,991,730 \mathrm{~cm}^{-1} ;{ }^{1} \mathrm{H} \mathrm{NMR}(400 \mathrm{MHz}$, $\left.\mathrm{CDCl}_{3}\right): \delta=5.01-4.98(\mathrm{~m}, 1 \mathrm{H}), 4.98-4.96(\mathrm{~m}, 1 \mathrm{H}), 4.23(\mathrm{dd}, J=5.7,1.5 \mathrm{~Hz}, 1 \mathrm{H}), 3.83($ br s, $1 \mathrm{H})$, 2.44-2.37 (m, $1 \mathrm{H}), 2.17-2.02(\mathrm{~m}, 3 \mathrm{H}), 2.02-1.93(\mathrm{~m}, 1 \mathrm{H}), 1.93-1.83(\mathrm{~m}, 1 \mathrm{H}), 1.80-1.67(\mathrm{~m}, 2 \mathrm{H})$, 1.66-1.56 (m, $5 \mathrm{H}), 1.55-1.40(\mathrm{~m}, 3 \mathrm{H}), 1.33-1.18(\mathrm{~m}, 3 \mathrm{H}), 1.21$ (s, $3 \mathrm{H}) \mathrm{ppm} ;{ }^{13} \mathrm{C} \mathrm{NMR}(126 \mathrm{MHz}$, $\left.\mathrm{CD}_{3} \mathrm{COCD}_{3}\right): \delta=182.0,156.2,109.0,85.8,73.7,73.3,49.2,48.2,45.5,38.9,36.7,34.3,32.8,32.4,31.8$ 31.5, 25.9, 19.8, 19.1, 17.7 ppm; HRMS (m/z): $[\mathrm{M}+\mathrm{H}]^{+}$calcd for $\mathrm{C}_{20} \mathrm{H}_{27} \mathrm{O}_{4}{ }^{+} 331.1904$, found 331.1911.

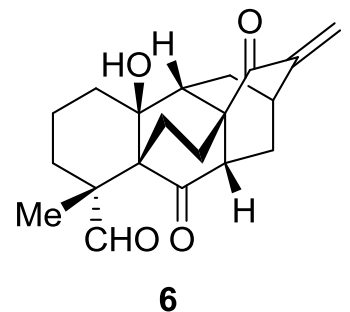

Diketoaldehyde 6: To a stirred solution of lactone $22(1.21 \mathrm{~g}, 3.66 \mathrm{mmol})$ in THF (35 mL) was added $\mathrm{LiAlH}_{4}(417 \mathrm{mg}, 11.0 \mathrm{mmol})$ at $22{ }^{\circ} \mathrm{C}$. The mixture was heated to $70{ }^{\circ} \mathrm{C}$ and allowed to stir at that 
temperature for $4 \mathrm{~h}$ before it was quenched with saturated aq. $\mathrm{NH}_{4} \mathrm{Cl}(100 \mathrm{~mL})$. The resultant mixture was extracted with $\mathrm{CH}_{2} \mathrm{Cl}_{2}(3 \times 150 \mathrm{~mL})$, and the combined organic phases were washed with brine (100 mL), dried over anhydrous $\mathrm{Na}_{2} \mathrm{SO}_{4}$, and filtered. The solvent was evaporated under vacuum, and the residue was subjected to the next step without further purification. To a stirred solution of pyridine (7.24 g, $7.40 \mathrm{~mL}, 91.5 \mathrm{mmol})$ in $\mathrm{CH}_{2} \mathrm{Cl}_{2}(20 \mathrm{~mL})$ were sequentially added celite $(13.2 \mathrm{~g})$ and $\mathrm{CrO}_{3}(4.39$ $\mathrm{g}, 43.9 \mathrm{mmol}$ ) at $22{ }^{\circ} \mathrm{C}$. ${ }^{6}$ The resultant mixture was stirred at that temperature for 15 min before a solution of above residue in $\mathrm{CH}_{2} \mathrm{Cl}_{2}(35 \mathrm{~mL})$ was added. The mixture was stirred at $22{ }^{\circ} \mathrm{C}$ for 20 min before it was filtered through a short pad of celite and washed with $\mathrm{CH}_{2} \mathrm{Cl}_{2}(3 \times 100 \mathrm{~mL})$. The combined organic phases were washed with brine $(100 \mathrm{~mL})$, dried over anhydrous $\mathrm{Na}_{2} \mathrm{SO}_{4}$, and filtered. The volatiles were removed under vacuum, and the residue was purified by flash column chromatography with EtOAc/petroleum ether $(1: 4 \rightarrow 1: 2)$ to diketoaldehyde 6 (696 mg, 58\% for the two steps) as a white foam. 6: $R_{\mathrm{f}}=0.29$ (silica, EtOAc:petroleum ether $\left.1: 2\right) ;[\alpha]_{\mathrm{D}}^{25}=-50.3(c=1.0$ in $\mathrm{CHCl}_{3}$ ); IR (film): $v_{\max }=3482,2959,2923,2853,1701,1626,1465,1378,1261,1096,1018,797 \mathrm{~cm}^{-1}$; ${ }^{1} \mathrm{H}$ NMR (400 MHz, $\left.\mathrm{CDCl}_{3}\right): \delta=9.55(\mathrm{~s}, 1 \mathrm{H}), 5.96(\mathrm{~d}, J=1.3 \mathrm{~Hz}, 1 \mathrm{H}), 5.20(\mathrm{~d}, J=1.3 \mathrm{~Hz}, 1 \mathrm{H})$, 2.77-2.70 (m, $1 \mathrm{H}), 2.51-2.42(\mathrm{~m}, 1 \mathrm{H}), 2.34-2.25(\mathrm{~m}, 1 \mathrm{H}), 2.21-2.14(\mathrm{~m}, 1 \mathrm{H}), 2.13-2.03(\mathrm{~m}, 3 \mathrm{H})$, 2.03-1.96 (m, $1 \mathrm{H}), 1.95-1.83(\mathrm{~m}, 3 \mathrm{H}), 1.83-1.72(\mathrm{~m}, 3 \mathrm{H}), 1.69-1.60$ (m, $2 \mathrm{H}), 1.60-1.51(\mathrm{~m}, 2 \mathrm{H})$, $1.21(\mathrm{~s}, 3 \mathrm{H}) \mathrm{ppm} ;{ }^{13} \mathrm{C} \mathrm{NMR}\left(126 \mathrm{MHz}, \mathrm{CDCl}_{3}\right): \delta=217.0,205.6,200.6,146.7,117.0,77.7,58.3,48.5$, 47.6, 46.5, 44.5, 36.1, 35.1, 32.2, 30.8, 28.4, 21.2, 20.0, 19.5, 16.5 ppm; HRMS $(m / z):[\mathrm{M}+\mathrm{Na}]^{+}$calcd for $\mathrm{C}_{20} \mathrm{H}_{24} \mathrm{O}_{4} \mathrm{Na}^{+} 351.1567$, found 351.1565 .

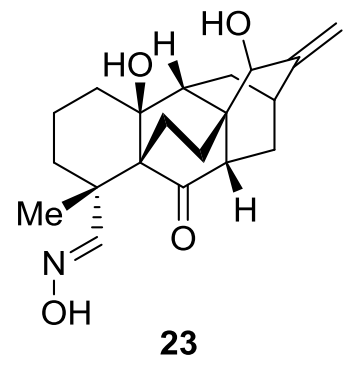

Oxime 23: To a stirred solution of diketoaldehyde 6 (319 mg, $0.971 \mathrm{mmol})$ in $\mathrm{MeOH}(10 \mathrm{~mL})$ were sequentially added $\mathrm{NaOAc}(95.6 \mathrm{mg}, 1.17 \mathrm{mmol})$ and $\mathrm{NH}_{2} \mathrm{OH} \cdot \mathrm{HCl}(68.8 \mathrm{mg}, 0.990 \mathrm{mmol})$ at $22{ }^{\circ} \mathrm{C}$. The mixture was allowed to stir at that temperature for $2 \mathrm{~h}$ before the solvent was evaporated under 
vacuum. The residue was dissolved in THF/MeOH $(11 \mathrm{~mL}, 10: 1)$. To the stirred solution was added $\mathrm{NaBH}_{4}(73.3 \mathrm{mg}, 1.94 \mathrm{mmol})$ at $-78^{\circ} \mathrm{C}$. The mixture was stirred at that temperature for $15 \mathrm{~min}$ before it was quenched with saturated aq. $\mathrm{Na}_{2} \mathrm{HCO}_{3}(50 \mathrm{~mL})$. The organic layer was separated, and the aqueous layer was extracted with EtOAc $(3 \times 100 \mathrm{~mL})$. The combined organic phases were washed with brine (50 mL), dried over anhydrous $\mathrm{Na}_{2} \mathrm{SO}_{4}$, and filtered. The residue was subjected to flash column chromatography for purification using $\mathrm{MeOH} / \mathrm{CH}_{2} \mathrm{Cl}_{2}(1: 30 \rightarrow 1: 15)$ as eluent to give oxime 23 (218 $\mathrm{mg}, 65 \%)$ as a pale yellow oil. 23: $R_{\mathrm{f}}=0.32$ (silica, $\left.\mathrm{MeOH}: \mathrm{CH}_{2} \mathrm{Cl}_{2} 1: 15\right) ;[\alpha]_{\mathrm{D}}^{25}=-21.6(c=1.0$ in $\mathrm{CH}_{3} \mathrm{OH}$ ); IR (film): $v_{\max }=3447,2960,2925,2870,1702,1647,1461,1261,1097,1036,799 \mathrm{~cm}^{-1} ;{ }^{1} \mathrm{H}$ NMR (400 MHz, CD 3 OD): $\delta=7.52(\mathrm{~s}, 1 \mathrm{H}), 5.04-4.99(\mathrm{~m}, 1 \mathrm{H}), 4.94-4.89(\mathrm{~m}, 1 \mathrm{H}), 3.98-3.93(\mathrm{~m}, 1$ H), 2.40-2.24 (m, 2 H), 2.24-2.14 (m, 2 H), 2.08-1.97 (m, 2 H), 1.97-1.90 (m, 1 H), 1.90-1.80 (m, 1 $\mathrm{H}), 1.74-1.57(\mathrm{~m}, 4 \mathrm{H}), 1.54-1.37(\mathrm{~m}, 5 \mathrm{H}), 1.34(\mathrm{~s}, 3 \mathrm{H}) \mathrm{ppm} ;{ }^{13} \mathrm{C} \mathrm{NMR}\left(126 \mathrm{MHz}, \mathrm{CD}_{3} \mathrm{OD}\right): \delta=$ $220.2,160.8,155.8,107.7,78.2,73.98,58.8,47.8,44.9,41.4,40.5,37.2,36.4,35.4,31.1,30.1,26.1$ 23.9, 20.0, 18.0 ppm; HRMS (m/z): $[\mathrm{M}+\mathrm{H}]^{+}$calcd for $\mathrm{C}_{20} \mathrm{H}_{28} \mathrm{NO}_{4}{ }^{+}$346.2013, found 346.2016.

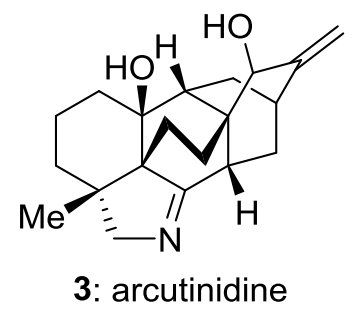

Arcutinidine (3): To a stirred solution of oxime 23 (197 mg, $0.570 \mathrm{mmol})$ and $\mathrm{NH}_{4} \mathrm{OAc}(879 \mathrm{mg}, 11.4$ mmol) in $\mathrm{MeOH}(5.0 \mathrm{~mL})$ were sequentially added $\mathrm{NaBH}_{3} \mathrm{CN}(107 \mathrm{mg}, 1.70 \mathrm{mmol})$ and $\mathrm{TiCl}_{3}[1.30 \mathrm{~mL}$, $20 \% \mathrm{w} / \mathrm{v}$ in aq. $\mathrm{HCl}(2.0 \mathrm{M}), 1.70 \mathrm{mmol}]$ at $0{ }^{\circ} \mathrm{C}$. The mixture was stirred at that temperature for $1 \mathrm{~h}$ before $1 \mathrm{~N} \mathrm{NaOH}$ was added until $\mathrm{pH}=10$. The resultant mixture was allowed to stir at $22{ }^{\circ} \mathrm{C}$ for $10 \mathrm{~min}$ before it was extracted with EtOAc $(4 \times 30 \mathrm{~mL})$. The combined organic phases were washed with brine (40 mL), dried over anhydrous $\mathrm{Na}_{2} \mathrm{SO}_{4}$, and filtered. The volatiles were removed under vacuum, and the residue was purified by flash column chromatography with $\mathrm{MeOH} / \mathrm{CH}_{2} \mathrm{Cl}_{2}$ (1:30) to give arcutinidine (3; $127 \mathrm{mg}, 71 \%$ ) as a white solid. 1: $R_{\mathrm{f}}=0.30$ (silica, $\mathrm{MeOH}: \mathrm{CH}_{2} \mathrm{Cl}_{2}$ 1:15); IR (film): $v_{\max }=3422,3072$, 2930, 2866, 1648, 1459, 1377, 1260, 1053, 972, $770 \mathrm{~cm}^{-1} ;{ }^{1} \mathrm{H}$ NMR $\left(500 \mathrm{MHz}, \mathrm{CDCl}_{3}\right): \delta=5.08-5.05$ 
(m, $1 \mathrm{H}), 5.01-4.97(\mathrm{~m}, 1 \mathrm{H}), 3.98(\mathrm{~s}, 1 \mathrm{H}), 3.71(\mathrm{dd}, J=15.3,2.2 \mathrm{~Hz}, 1 \mathrm{H}), 3.45(\mathrm{dd}, J=15.3,2.2 \mathrm{~Hz}$ $1 \mathrm{H}), 2.35-2.26(\mathrm{~m}, 2 \mathrm{H}), 2.12-2.03(\mathrm{~m}, 2 \mathrm{H}), 1.98-1.90(\mathrm{~m}, 2 \mathrm{H}), 1.89-1.84(\mathrm{~m}, 1 \mathrm{H}), 1.78-1.67$ (m, 3 $\mathrm{H}), 1.66-1.58(\mathrm{~m}, 3 \mathrm{H}), 1.57-1.51(\mathrm{~m}, 2 \mathrm{H}), 1.44-1.30(\mathrm{~m}, 4 \mathrm{H}), 0.95(\mathrm{~s}, 3 \mathrm{H}) \mathrm{ppm} ;{ }^{13} \mathrm{C}$ NMR $(126$ $\left.\mathrm{MHz}, \mathrm{CDCl}_{3}\right): \delta=186.4,155.4,108.6,75.1,73.6,73.3,58.9,42.6,41.0,40.3,37.2,35.4,32.7,31.8$, 30.7, 28.9, 26.1, 23.6, 20.2, 16.6 ppm; $\operatorname{HRMS}(\mathrm{m} / \mathrm{z}):[\mathrm{M}+\mathrm{H}]^{+}$calcd for $\mathrm{C}_{20} \mathrm{H}_{28} \mathrm{NO}_{2}{ }^{+} 314.2115$, found 315.2117. CCDC 1914281 contains the supplementary crystallographic data of $\mathbf{1}$ [m.p.: $159-161{ }^{\circ} \mathrm{C}$ (EtOAc:petroleum ether 1:5)]. These data can be obtained free of charge from The Cambridge Crystallographic Data Centre via www.ccdc.cam.ac.uk/data_request/cif.

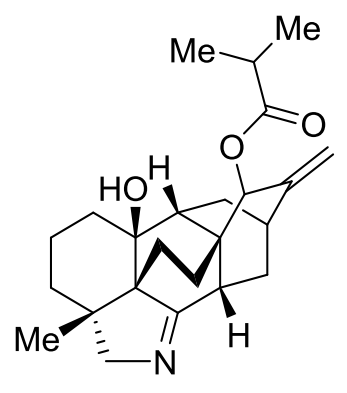

2: arcutinine

Arcutinine (2): To a stirred solution of $i-\mathrm{PrCO}_{2} \mathrm{H}(9.3 \mathrm{mg}, 0.106 \mathrm{mmol})$ and 4-DMAP (8.6 mg, 0.0704 mmol) in $\mathrm{CH}_{2} \mathrm{Cl}_{2}(100 \mu \mathrm{L})$ was added DCC $\left(100 \mu \mathrm{L}, 1.0 \mathrm{M}\right.$ in $\left.\mathrm{CH}_{2} \mathrm{Cl}_{2}, 0.100 \mathrm{mmol}\right)$ at $22{ }^{\circ} \mathrm{C}$. The mixture was stirred at that temperature for $5 \mathrm{~min}$ before a solution of arcutinidine $(3 ; 22.1 \mathrm{mg}, 0.0705$ mmol) in $\mathrm{CH}_{2} \mathrm{Cl}_{2}(600 \mu \mathrm{L})$ was added. The resultant mixture was allowed to stir at $22{ }^{\circ} \mathrm{C}$ for $3 \mathrm{~h}$ before it was quenched with saturated aq. $\mathrm{NaHCO}_{3}(10 \mathrm{~mL})$. The resultant mixture was extracted with EtOAc $(3 \times 20 \mathrm{~mL})$. The combined organic phases were washed with brine $(10 \mathrm{~mL})$, dried over anhydrous $\mathrm{Na}_{2} \mathrm{SO}_{4}$, filtered, and concentrated under vacuum. The residue was purified by flash column chromatography with acetone $/ \mathrm{CH}_{2} \mathrm{Cl}_{2}(1: 10 \rightarrow 1: 5)$ to give arcutinine $(2 ; 20.8 \mathrm{mg}, 77 \%)$ as a white solid. 2: $R_{\mathrm{f}}=0.26$ (silica, acetone: $\left.\mathrm{CH}_{2} \mathrm{Cl}_{2} 1: 10\right) ;[\alpha]_{\mathrm{D}}^{25}=-15.4\left(c=0.50\right.$ in $\left.\mathrm{CHCl}_{3}\right)$; IR (film): $v_{\max }=$ 3218, 2959, 2926, 2854, 1734, 1649, 1457, 1385, 1189, 1154, 1097, 1009, 975, $945 \mathrm{~cm}^{-1} ;{ }^{1} \mathrm{H}$ NMR (400 $\left.\mathrm{MHz}, \mathrm{CDCl}_{3}\right): \delta=5.43-5.35(\mathrm{~m}, 1 \mathrm{H}), 4.98-4.92(\mathrm{~m}, 1 \mathrm{H}), 4.90-4.83(\mathrm{~m}, 1 \mathrm{H}), 3.70(\mathrm{dd}, J=15.3,2.2$ $\mathrm{Hz}, 1 \mathrm{H}), 3.45$ (dd, $J=15.3,2.2 \mathrm{~Hz}, 1 \mathrm{H}), 2.68-2.55(\mathrm{~m}, 1 \mathrm{H}), 2.48-2.38(\mathrm{~m}, 1 \mathrm{H}), 2.37-2.31(\mathrm{~m}, 1 \mathrm{H})$, 2.06-1.95 (m, $3 \mathrm{H}), 1.90-1.83$ (m, $1 \mathrm{H}), 1.81-1.71$ (m, $3 \mathrm{H}), 1.69-1.60$ (m, $2 \mathrm{H}), 1.60-1.51$ (m, $3 \mathrm{H})$, 
1.42-1.34 (m, $2 \mathrm{H}), 1.34-1.24(\mathrm{~m}, 2 \mathrm{H}), 1.21(\mathrm{~d}, J=3.9 \mathrm{~Hz}, 3 \mathrm{H}), 1.19(\mathrm{~d}, J=3.9 \mathrm{~Hz}, 3 \mathrm{H}), 0.95$ (s, $3 \mathrm{H})$ ppm; ${ }^{13} \mathrm{C}$ NMR $\left(126 \mathrm{MHz}, \mathrm{CDCl}_{3}\right): \delta=185.5,177.1,150.4,110.2,75.0,73.7,73.4,58.7,43.6,41.0$, 39.3, 37.1, 35.4, 34.4, 33.1, 32.2, 30.8, 28.6, 25.9, 23.3, 20.2, 19.3, 19.2, 16.7 ppm; HRMS $(m / z):[\mathrm{M}+$ $\mathrm{H}]^{+}$calcd for $\mathrm{C}_{24} \mathrm{H}_{34} \mathrm{NO}_{3}{ }^{+}$384.2533, found 384.2538. CCDC 1915624 contains the supplementary crystallographic data of 2 [m.p.: 245-247 ${ }^{\circ} \mathrm{C}\left(\mathrm{CH}_{2} \mathrm{Cl}_{2}\right.$ :petroleum ether 1:10)]. These data can be obtained free of charge from The Cambridge Crystallographic Data Centre via www.ccdc.cam.ac.uk/data_request/cif. 
II HPLC Traces for Measuring Enantiomeric Excess<smiles>O[C@H]1C=C(Br)CCC1</smiles>

13

The racemic and enantioenriched $\mathbf{1 3}$ were analyzed by HPLC (CHIRALPAK IG column, $i$-PrOH:hexane 2:98, $0.80 \mathrm{~mL} / \mathrm{min}$ ) to determine the retention time and enantiomeric excess. For 13, ee $=99.7 \%$.

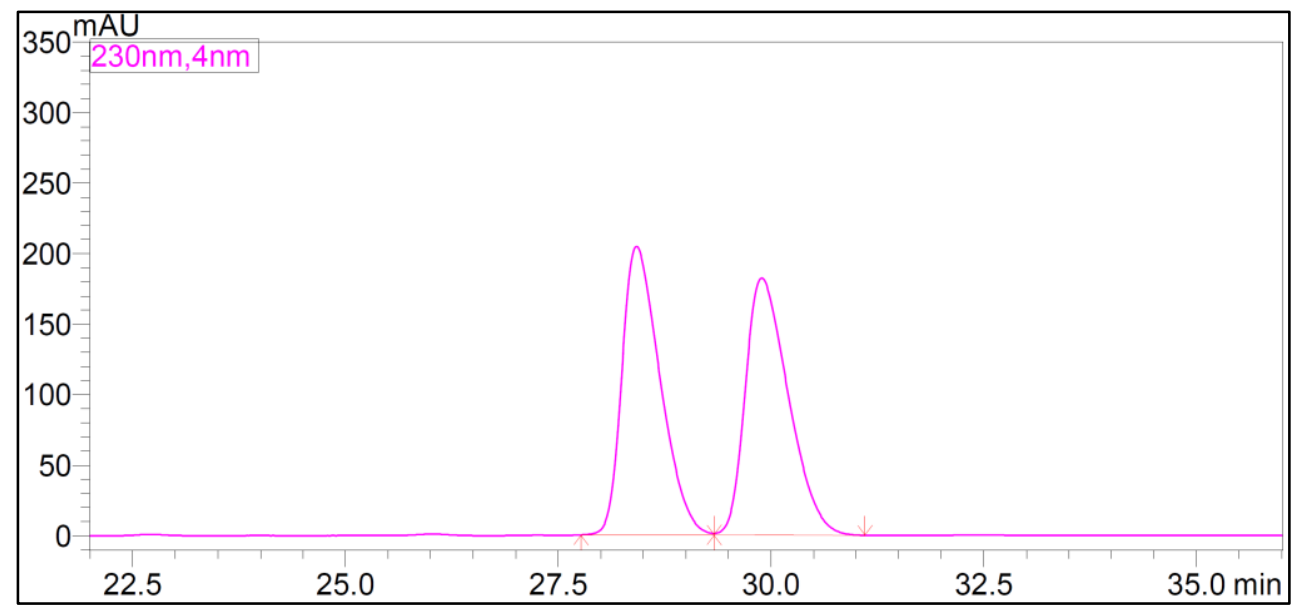

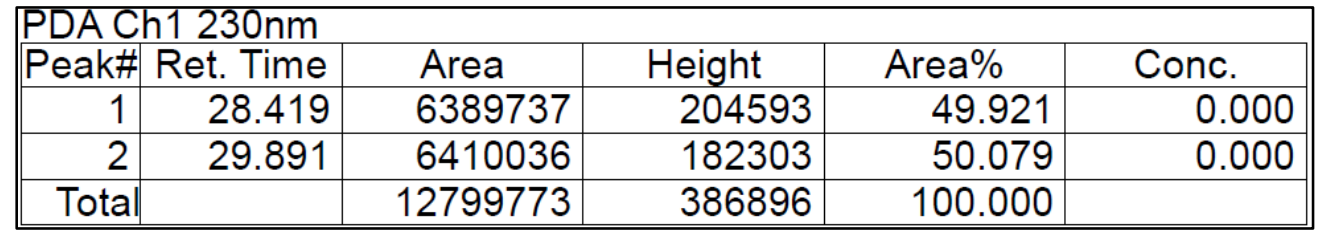

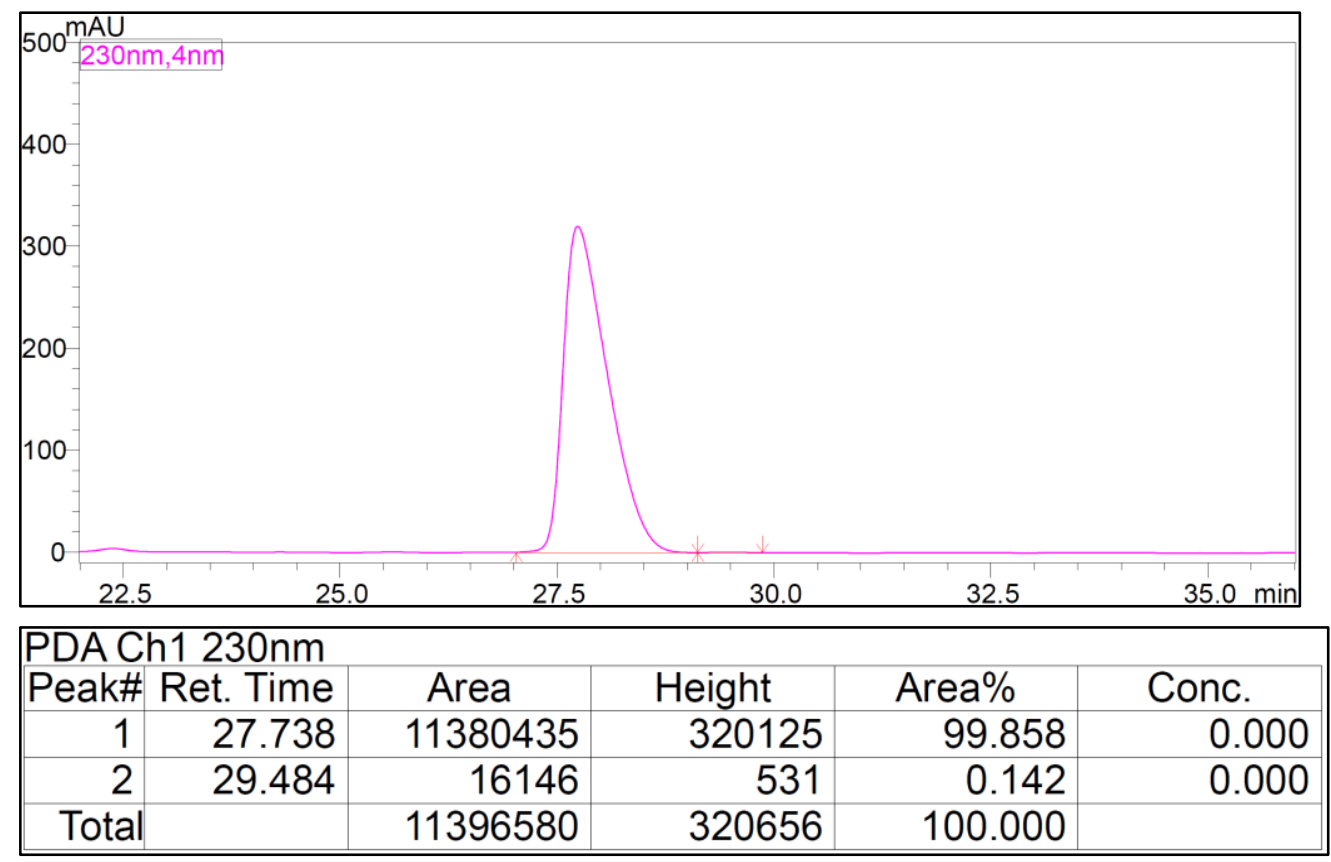


III ${ }^{1} \mathrm{H}$ and ${ }^{13} \mathrm{C}$ NMR Spectra of Compounds

${ }^{1} \mathrm{H}$ NMR Spectrum of $14\left(500 \mathrm{MHz}, \mathrm{CDCl}_{3}\right)$

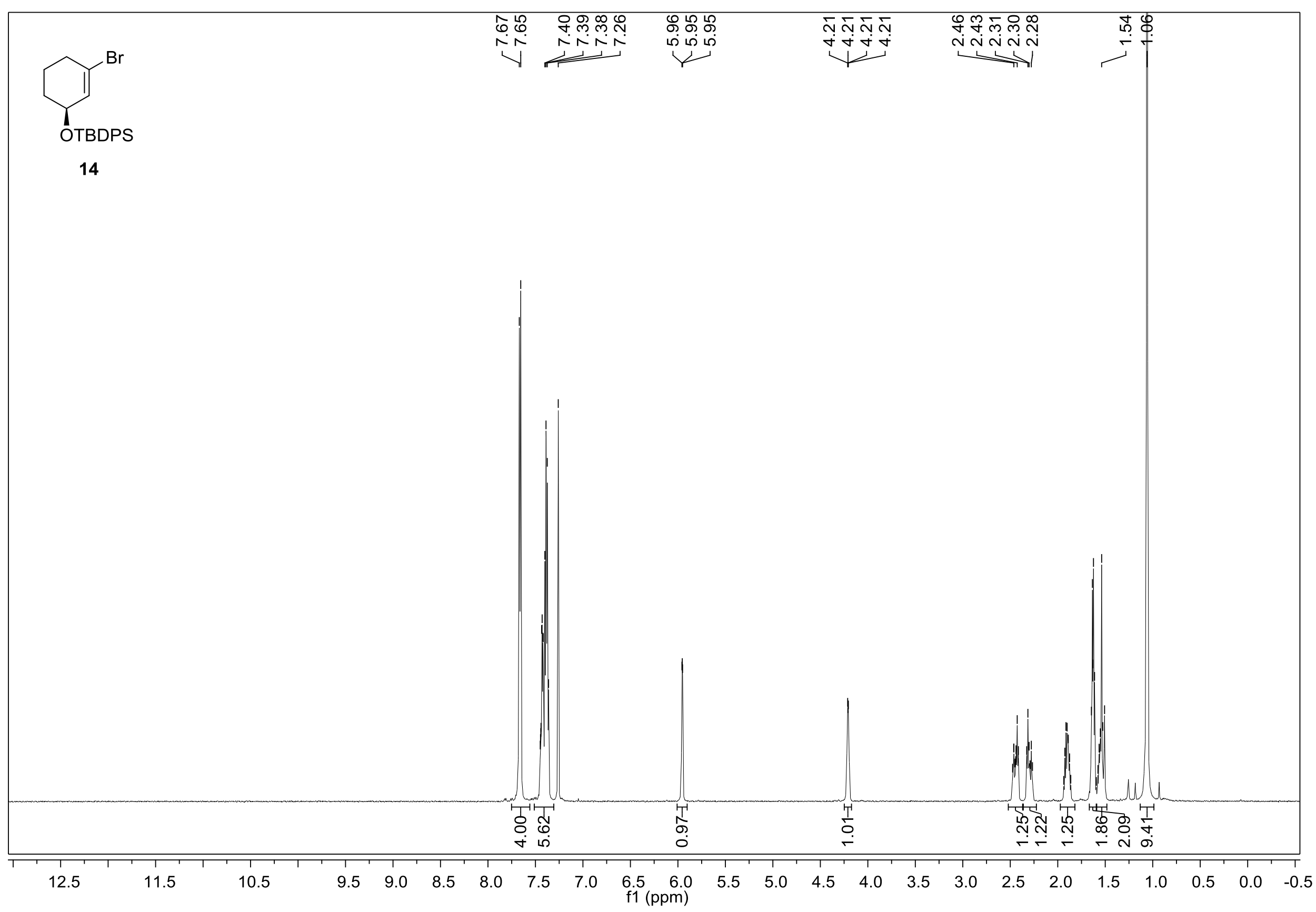


${ }^{13} \mathrm{C}$ NMR Spectrum of $14\left(101 \mathrm{MHz}, \mathrm{CDCl}_{3}\right)$

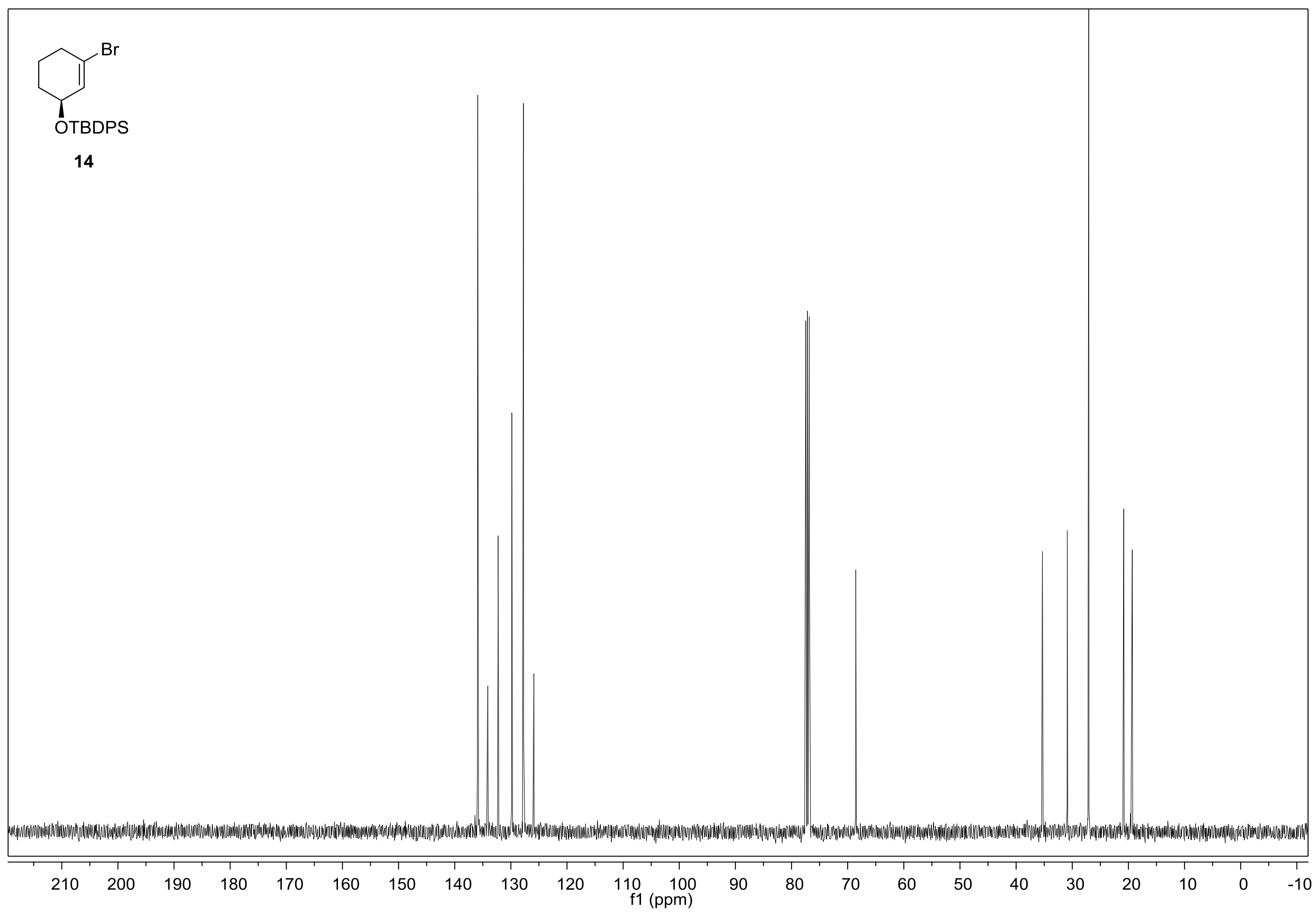


${ }^{1} \mathrm{H}$ NMR Spectrum of 12 (400 $\left.\mathrm{MHz}, \mathrm{CDCl}_{3}\right)$

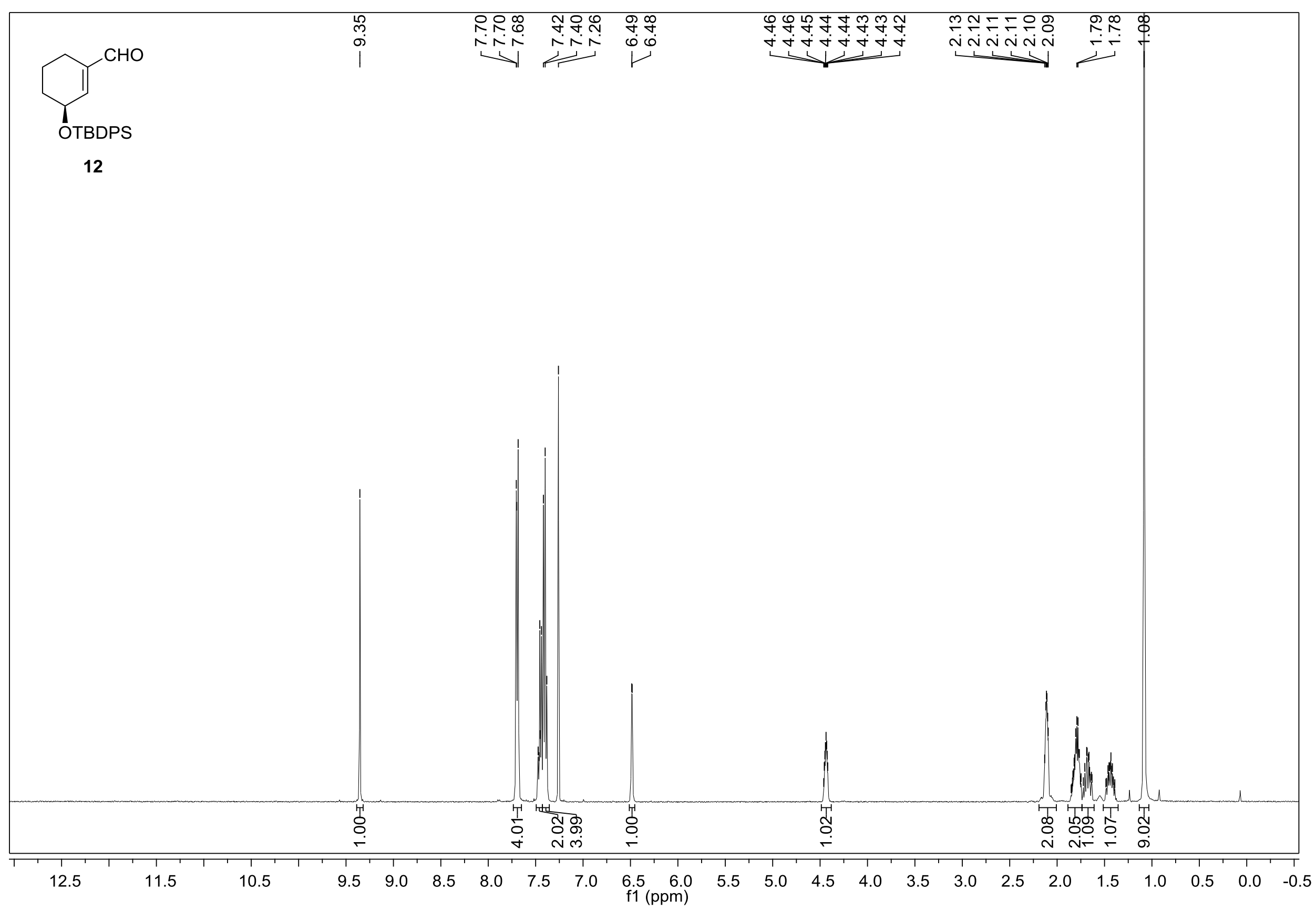


${ }^{13} \mathrm{C}$ NMR Spectrum of $12\left(101 \mathrm{MHz}, \mathrm{CDCl}_{3}\right)$

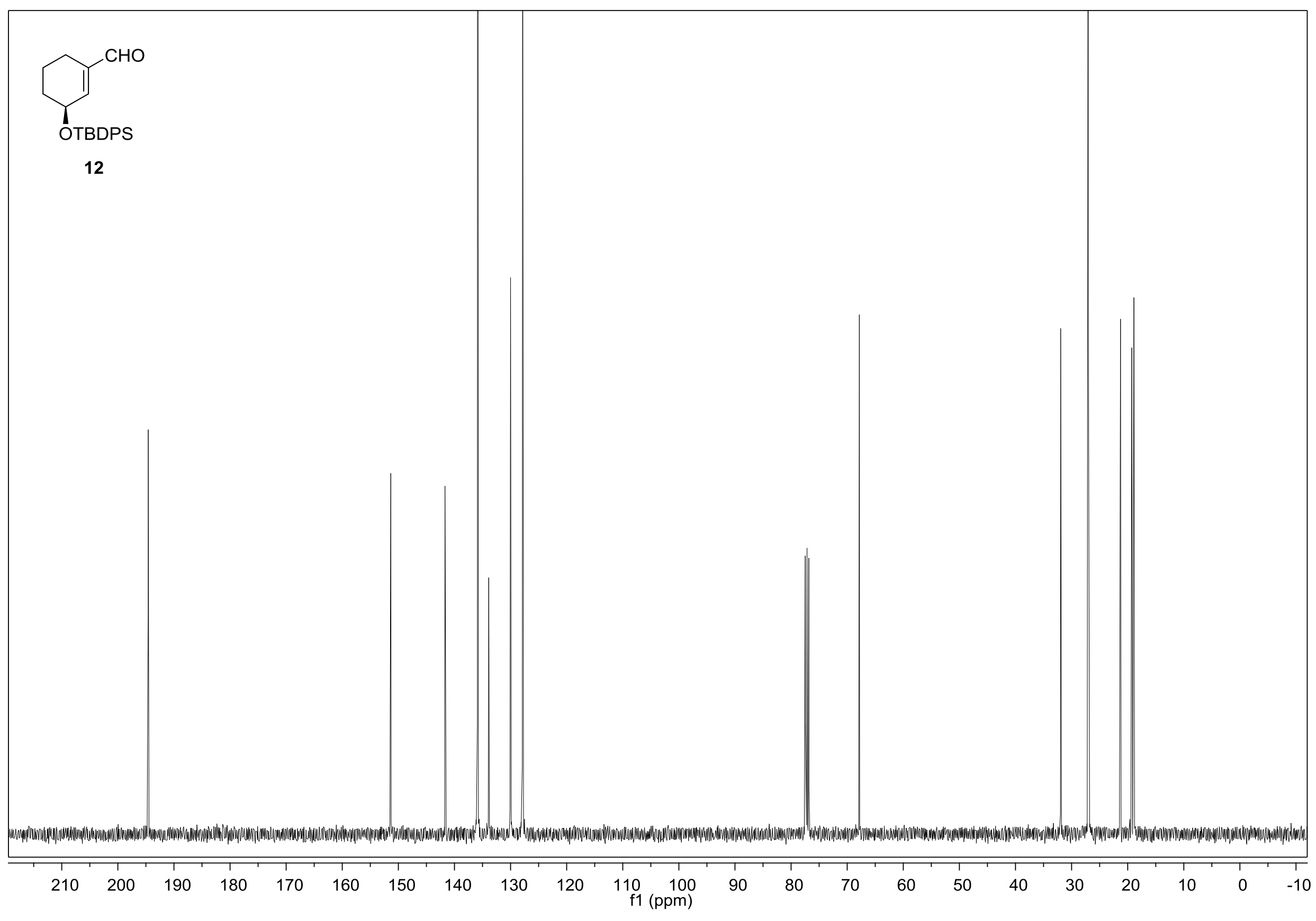


${ }^{1} \mathrm{H}$ NMR Spectrum of $10\left(400 \mathrm{MHz}, \mathrm{CDCl}_{3}\right)$

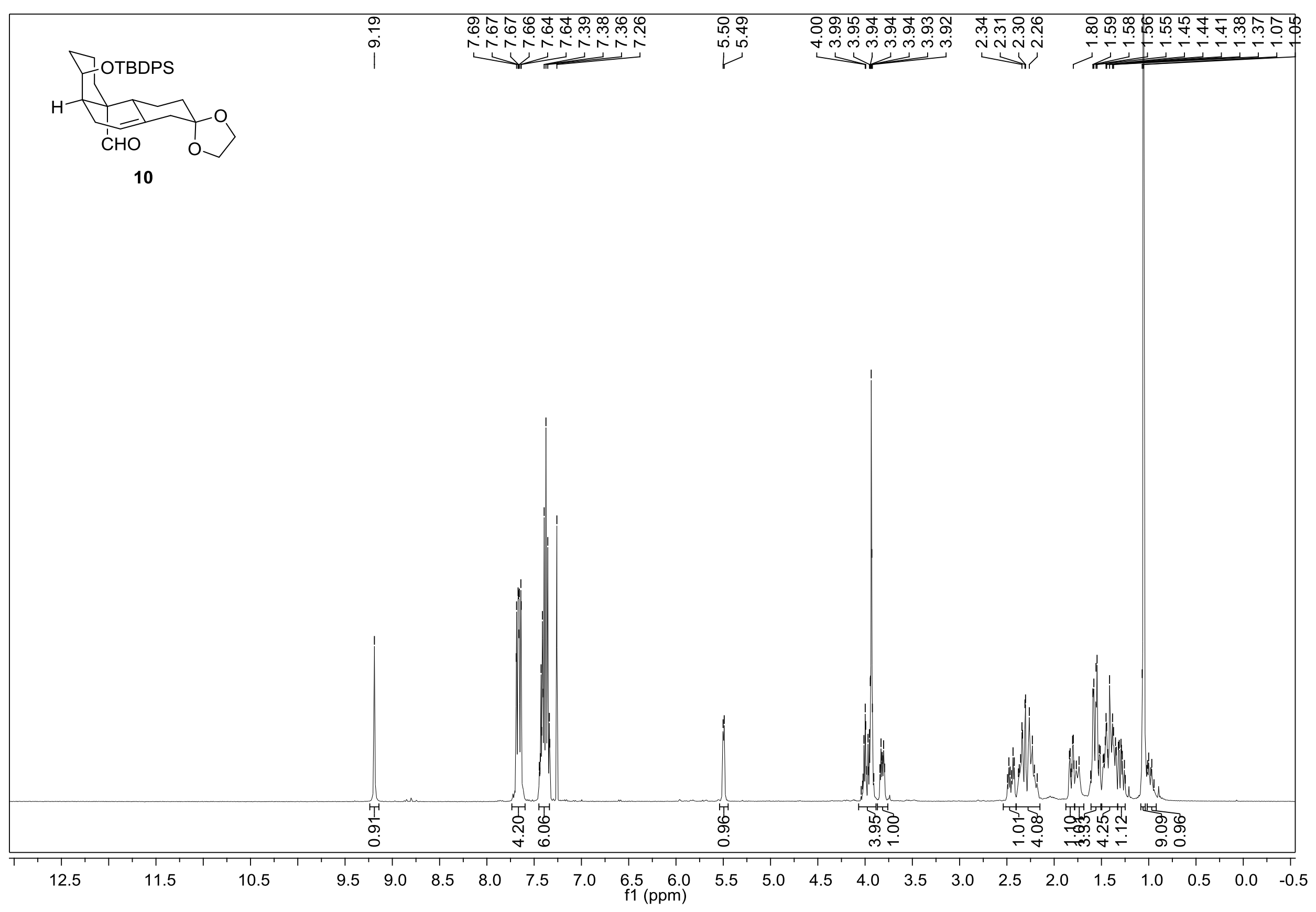


${ }^{13} \mathrm{C}$ NMR Spectrum of $10\left(101 \mathrm{MHz}, \mathrm{CD}_{3} \mathrm{COCD}_{3}\right)$

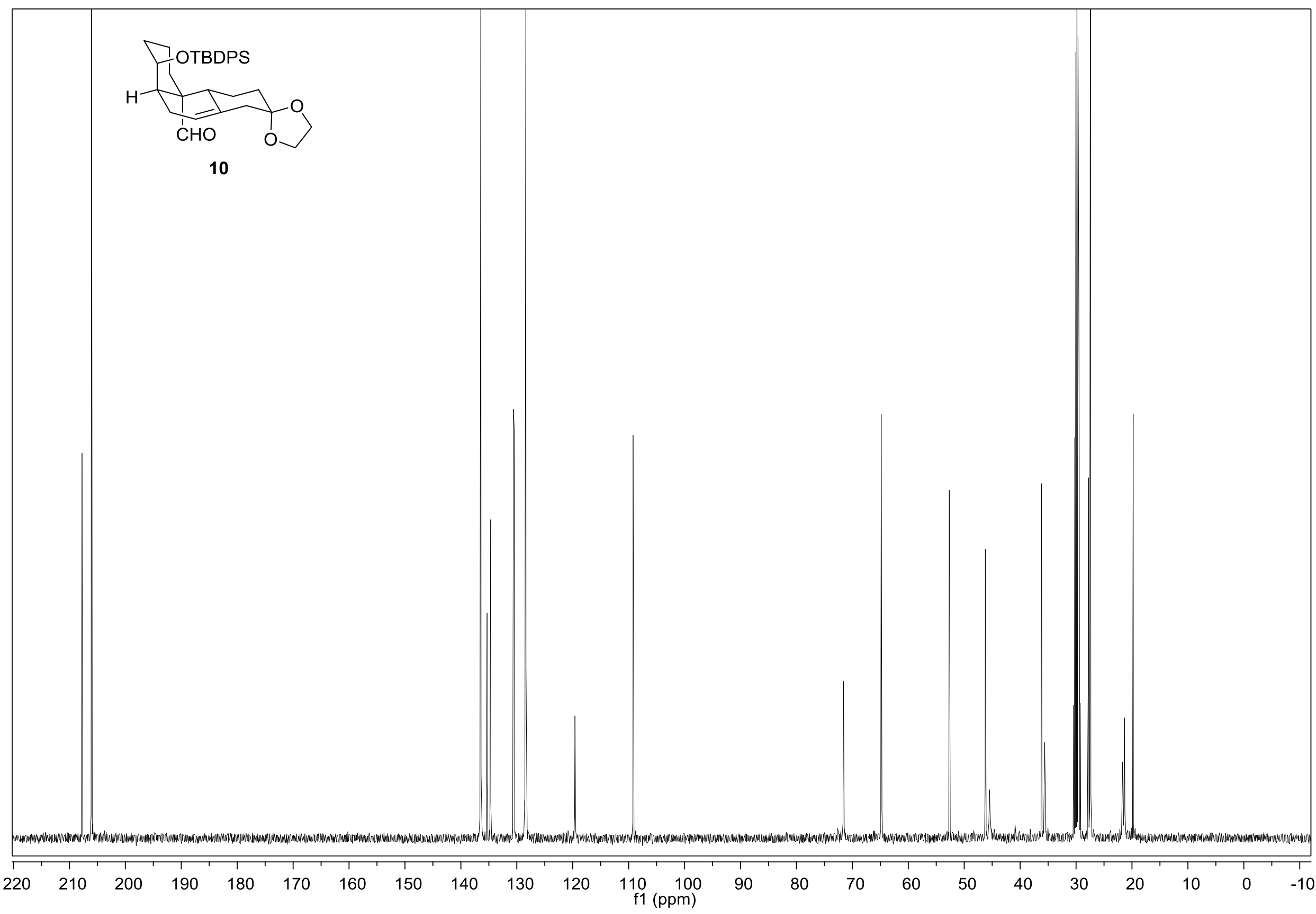


${ }^{1} \mathrm{H}$ NMR Spectrum of 15 (400 $\left.\mathrm{MHz}, \mathrm{CDCl}_{3}\right)$

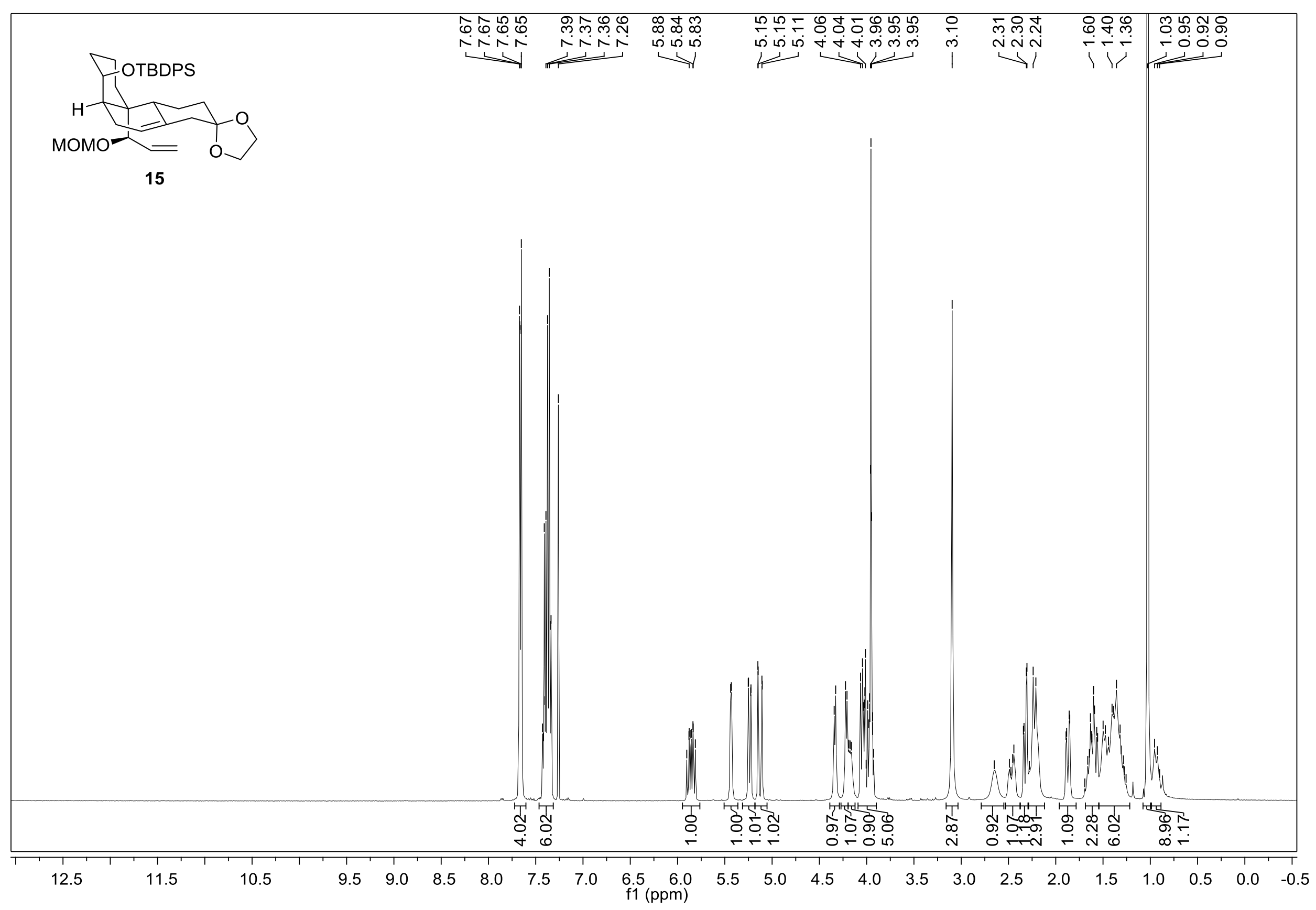


${ }^{13} \mathrm{C}$ NMR Spectrum of 15 (101 $\left.\mathrm{MHz}, \mathrm{CDCl}_{3}\right)$

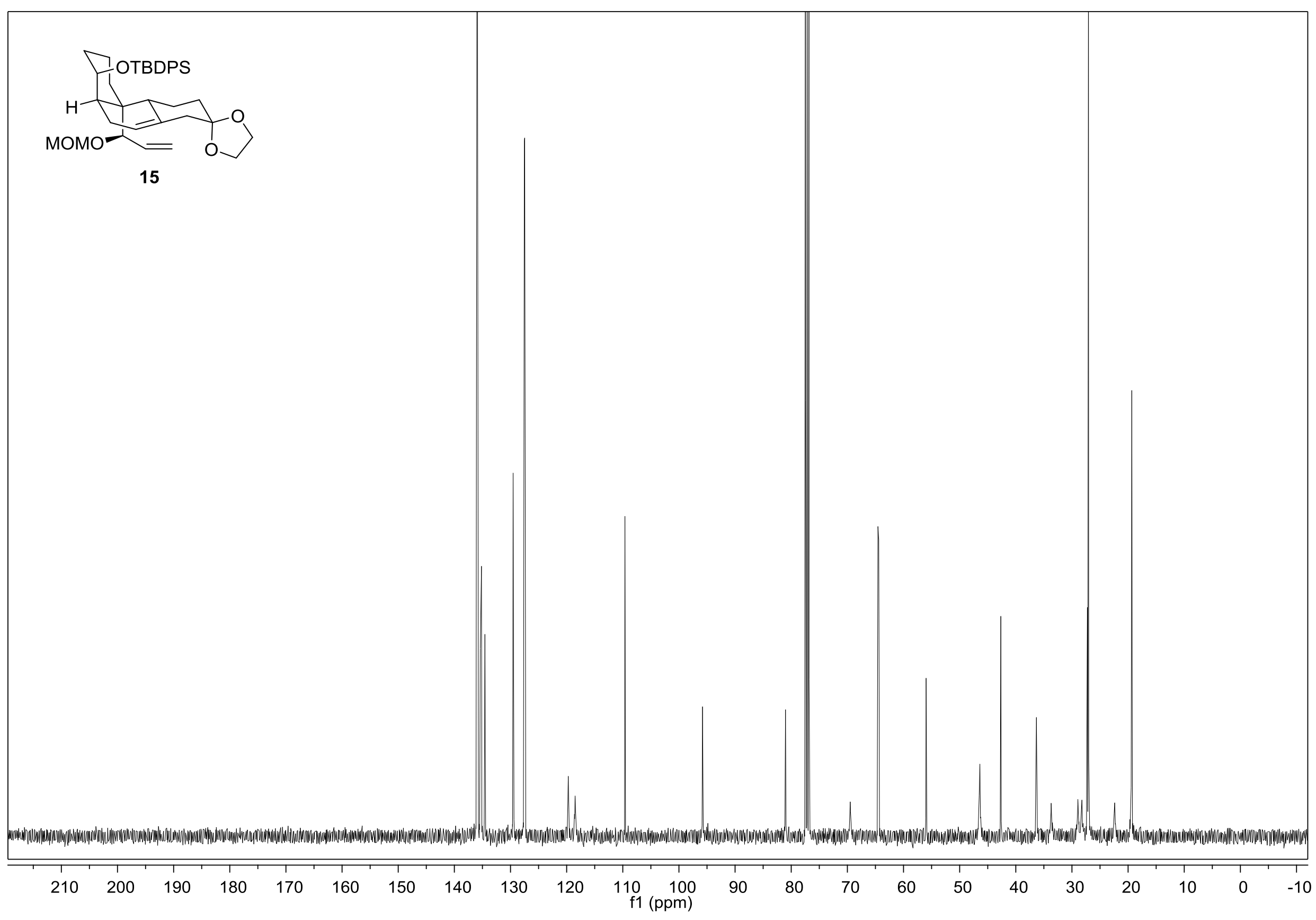


${ }^{1} \mathrm{H}$ NMR Spectrum of $9\left(400 \mathrm{MHz}, \mathrm{CDCl}_{3}\right)$

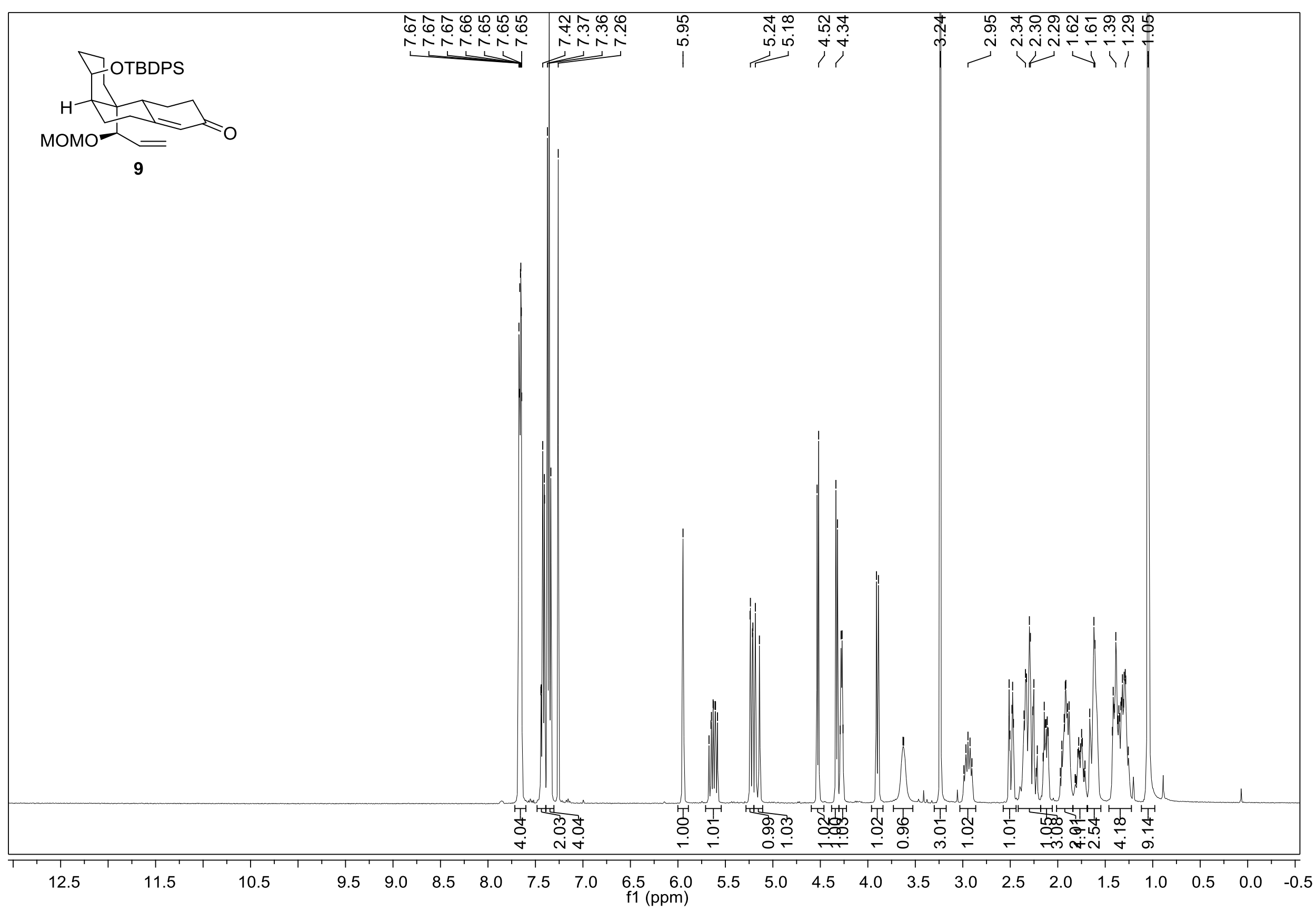


${ }^{13} \mathrm{C}$ NMR Spectrum of $9\left(101 \mathrm{MHz}, \mathrm{CDCl}_{3}\right)$

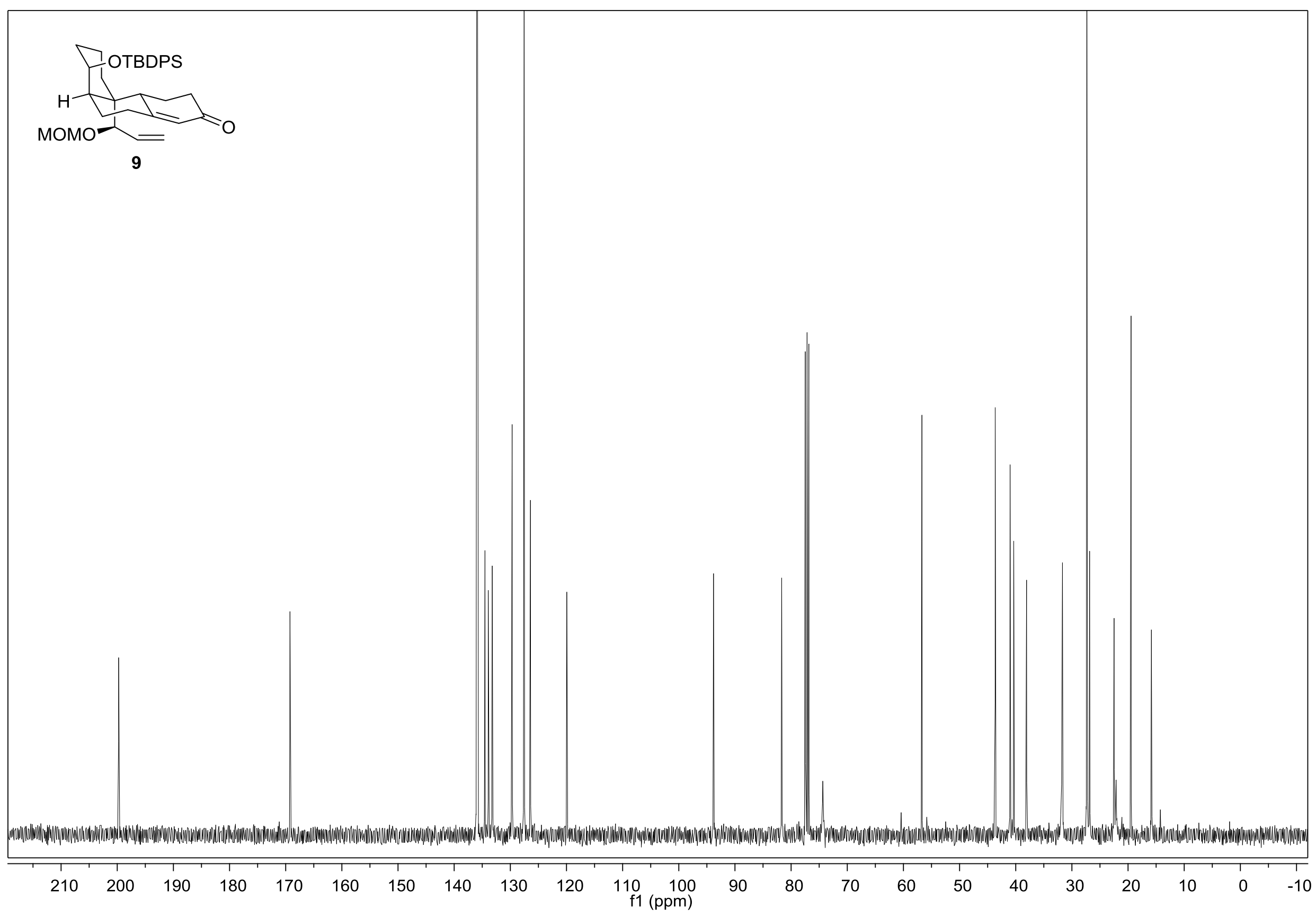


${ }^{1} \mathrm{H}$ NMR Spectrum of $16\left(500 \mathrm{MHz}, \mathrm{CDCl}_{3}\right)$

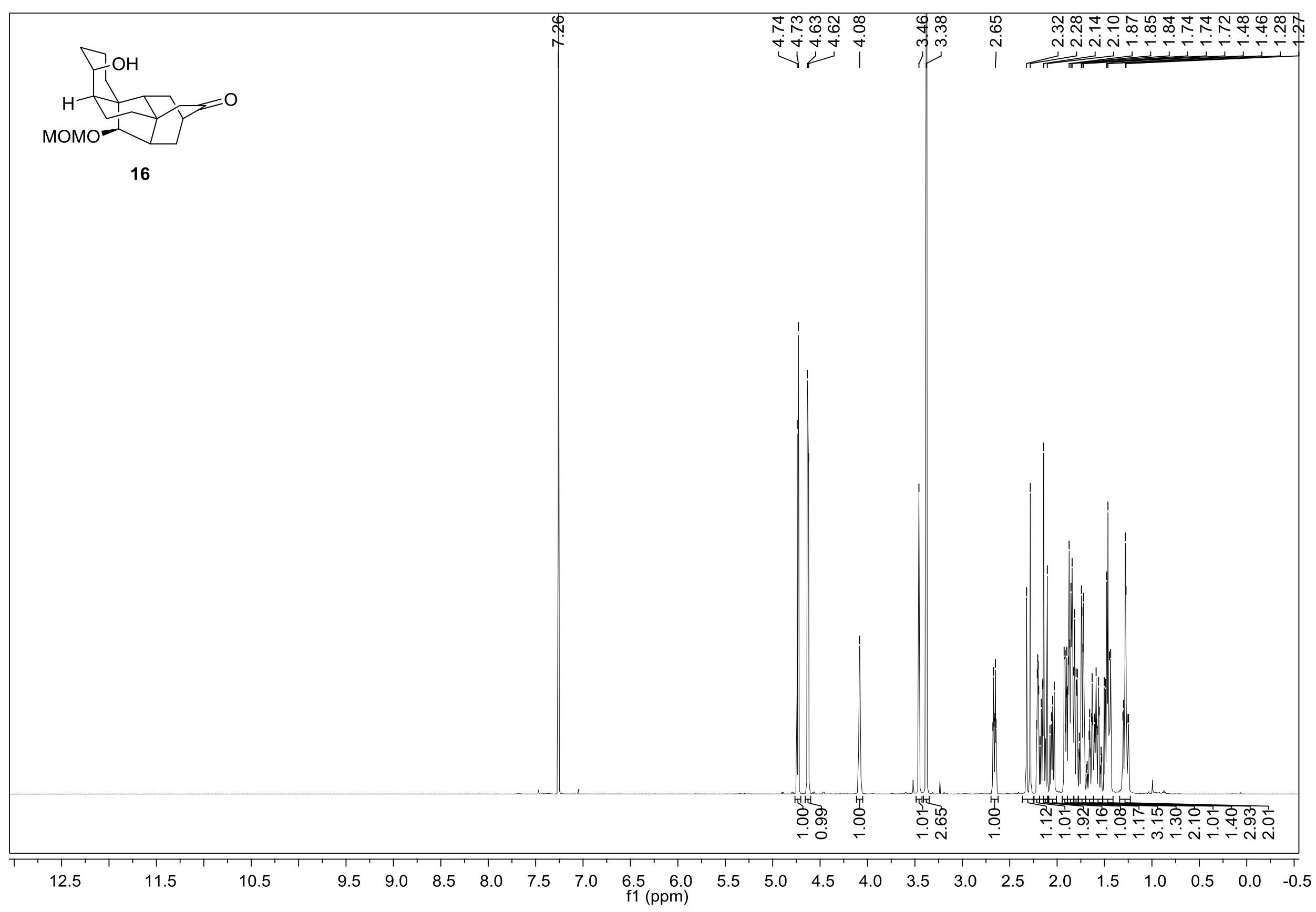


${ }^{13} \mathrm{C}$ NMR Spectrum of $16\left(126 \mathrm{MHz}, \mathrm{CDCl}_{3}\right)$

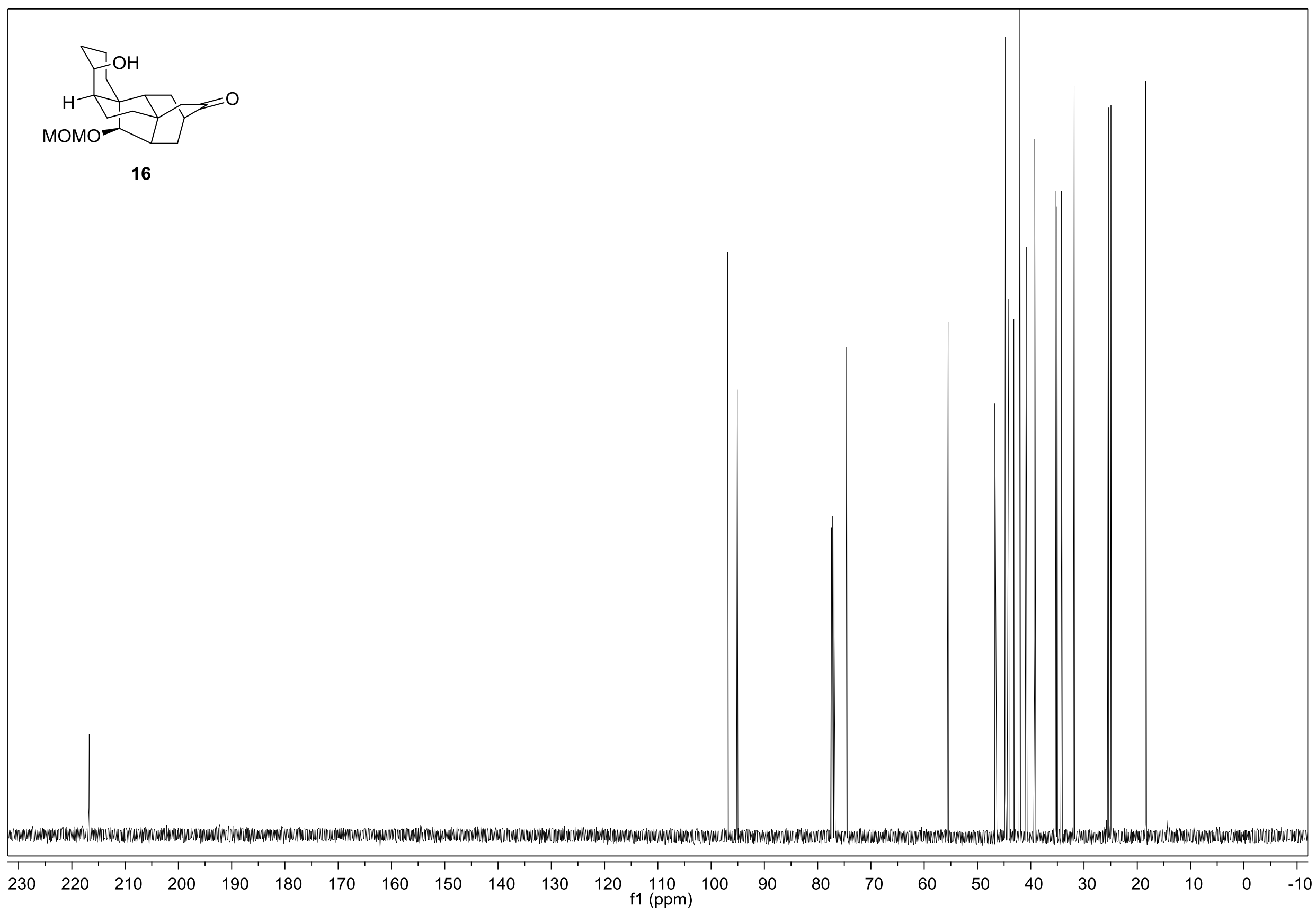


${ }^{1} \mathrm{H}$ NMR Spectrum of $8\left(500 \mathrm{MHz}, \mathrm{CDCl}_{3}\right)$

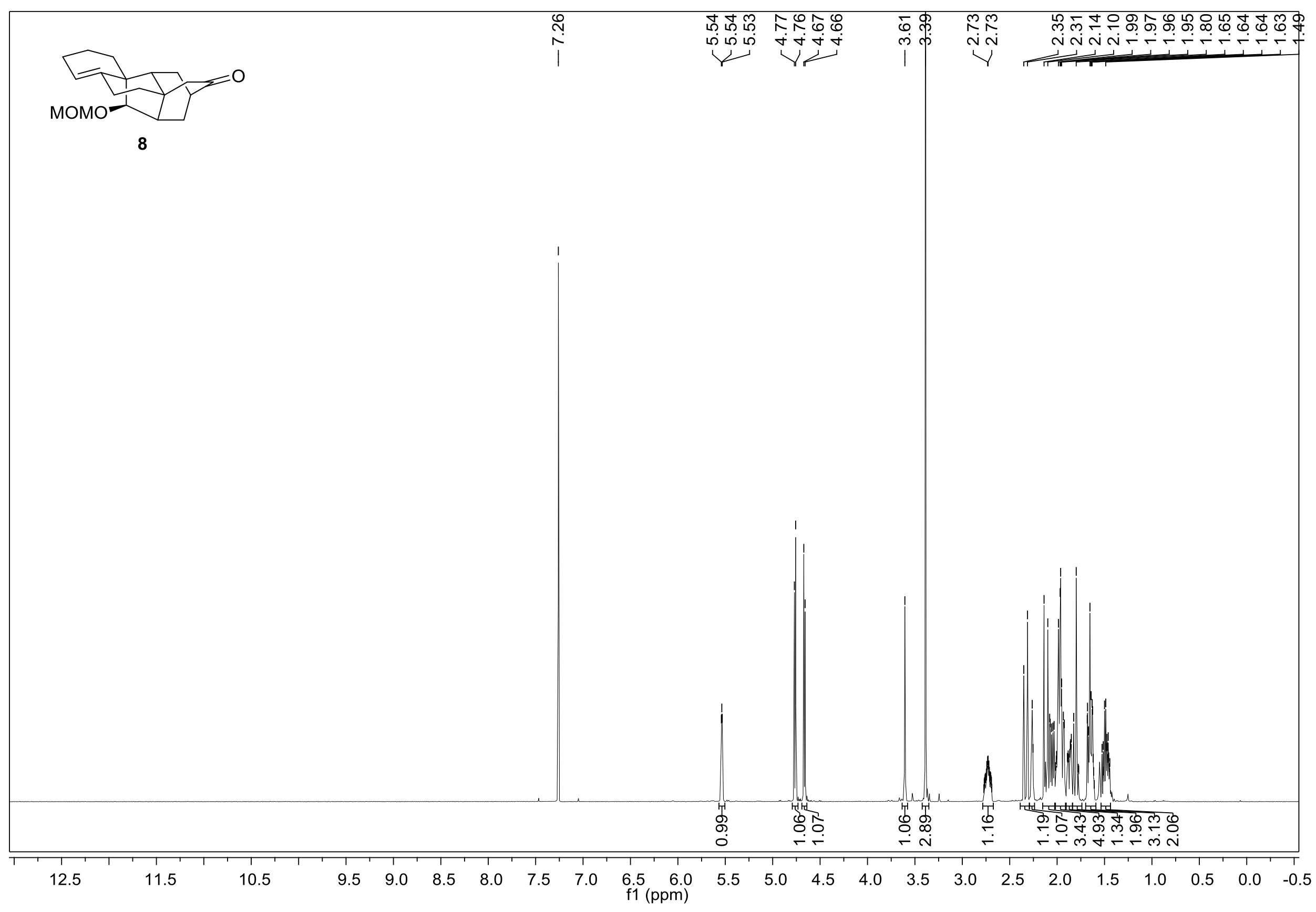




\section{${ }^{13} \mathrm{C}$ NMR Spectrum of $8\left(126 \mathrm{MHz}, \mathrm{CDCl}_{3}\right)$}

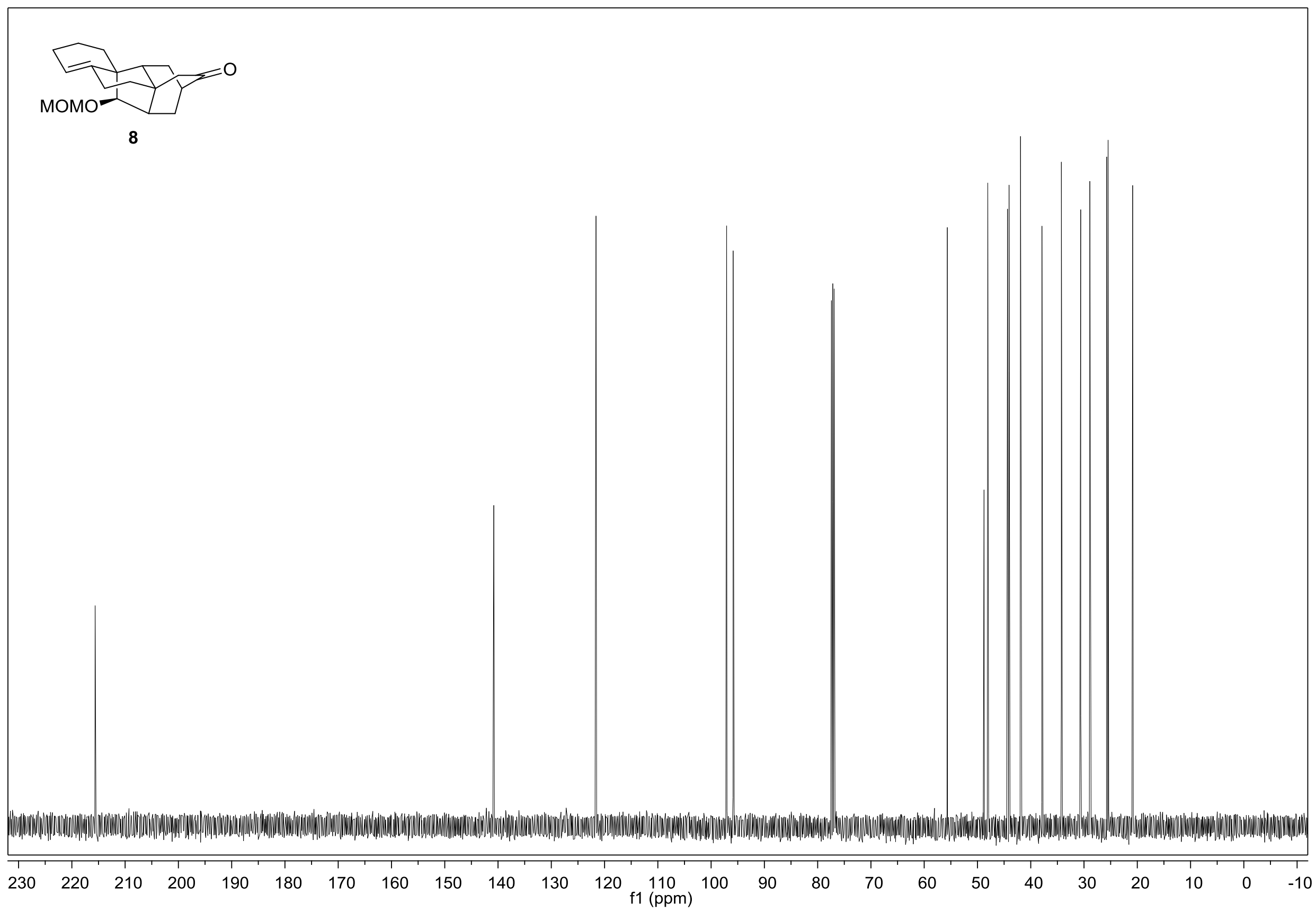


${ }^{1} \mathrm{H}$ NMR Spectrum of 7 (400 $\left.\mathrm{MHz}, \mathrm{CDCl}_{3}\right)$

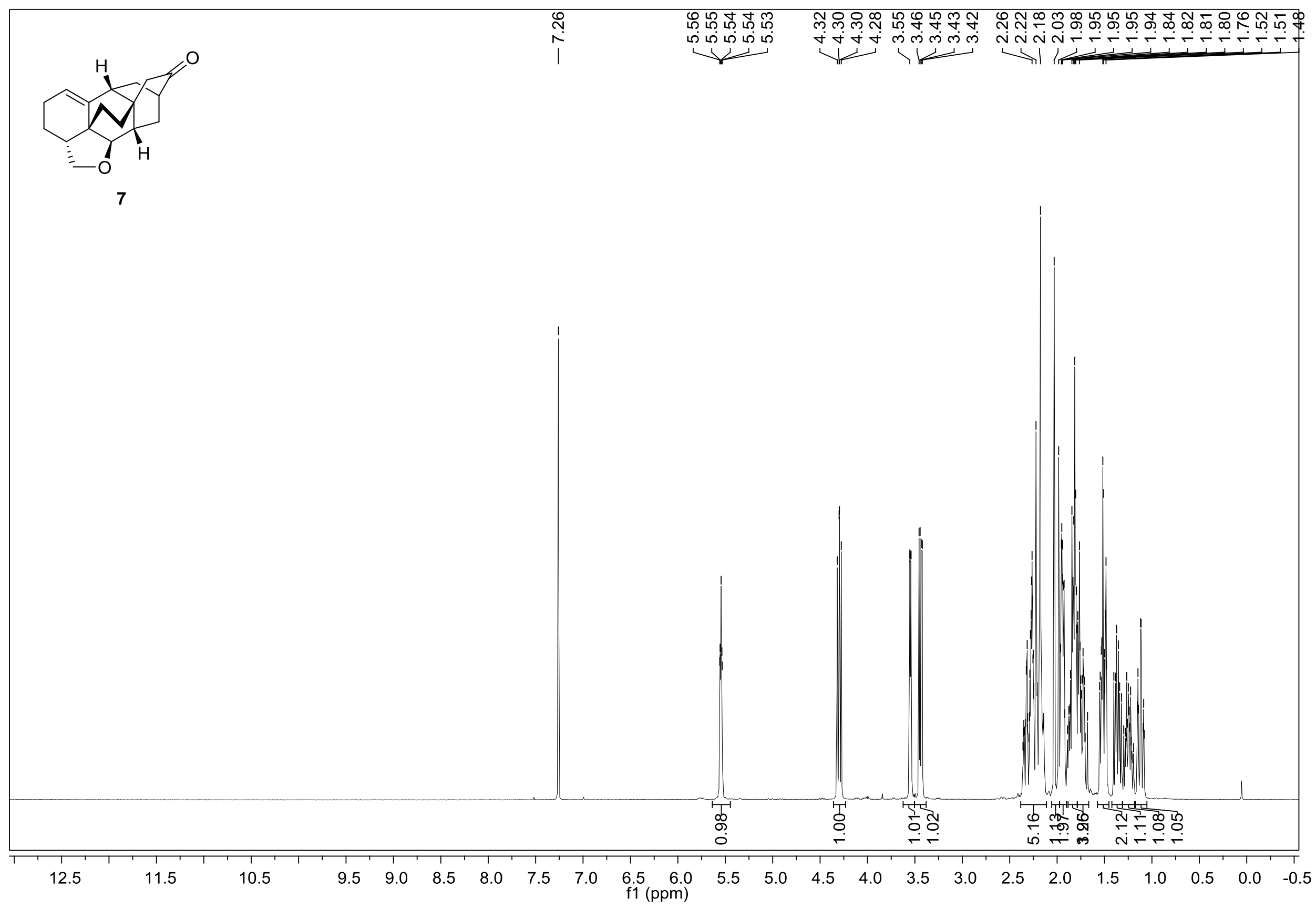


${ }^{13} \mathrm{C}$ NMR Spectrum of $7\left(126 \mathrm{MHz}, \mathrm{CDCl}_{3}\right)$

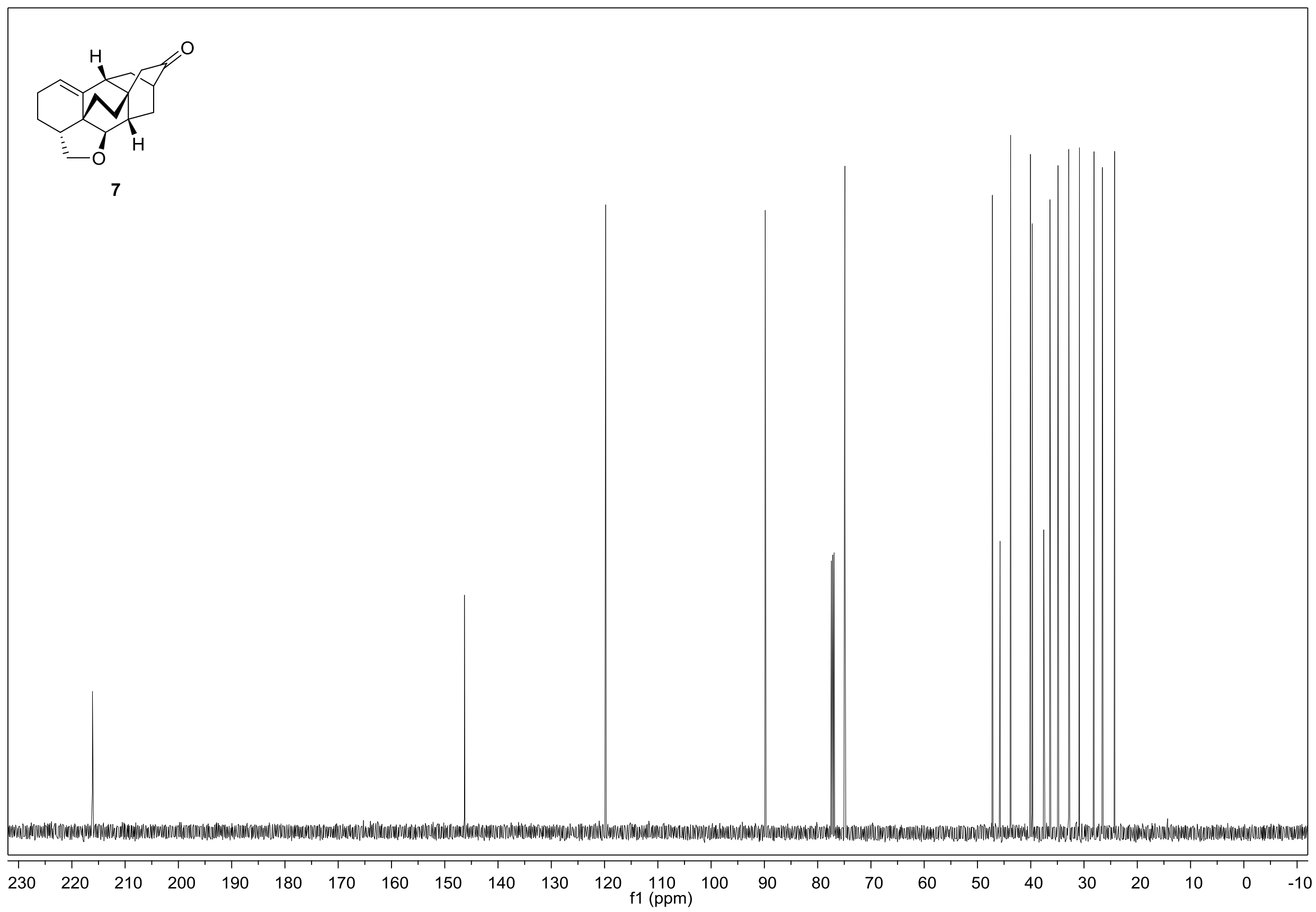


${ }^{1} \mathrm{H}$ NMR Spectrum of 19 (400 $\left.\mathrm{MHz}, \mathrm{CDCl}_{3}\right)$

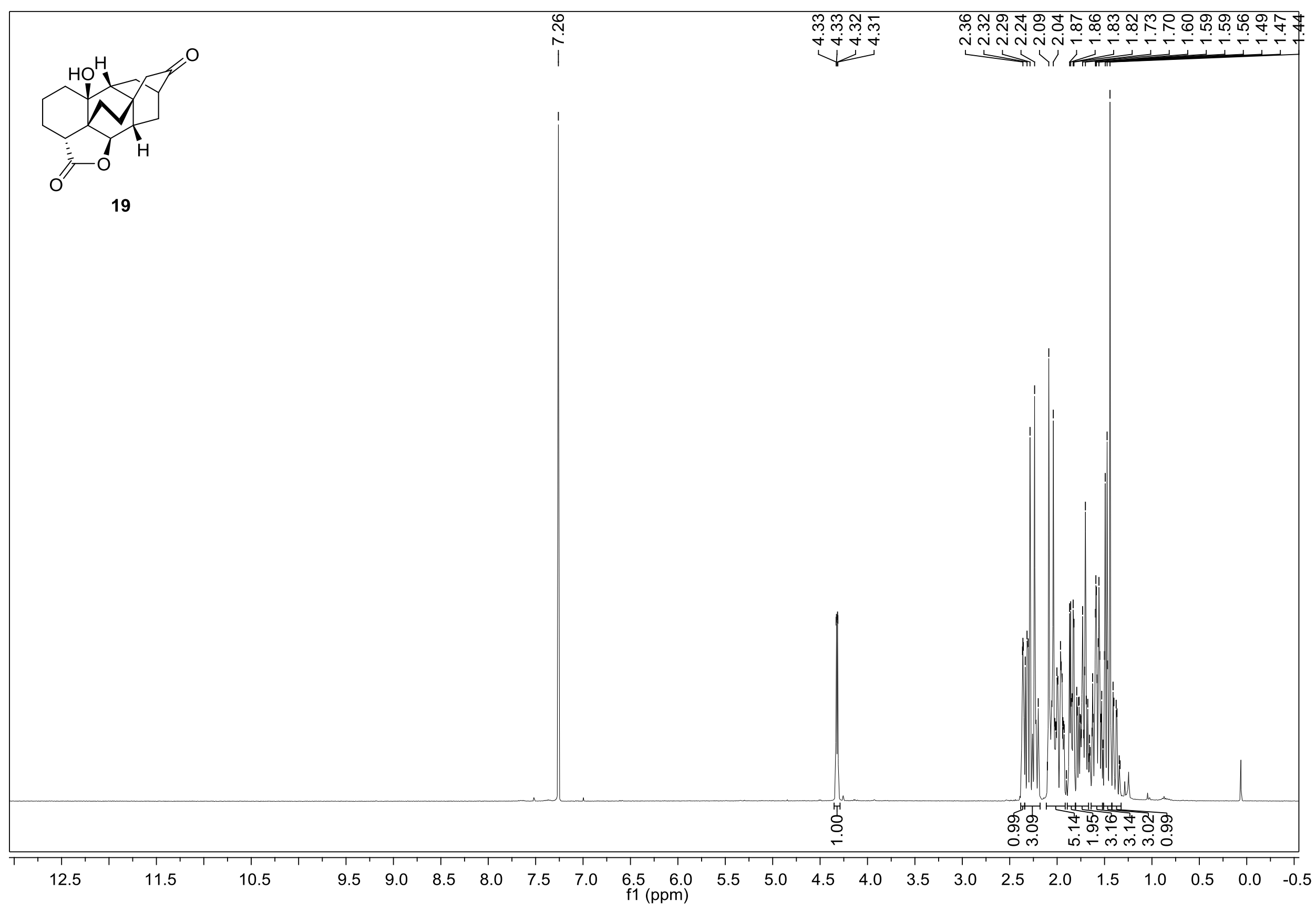




\section{${ }^{13} \mathrm{C}$ NMR Spectrum of $19\left(126 \mathrm{MHz}, \mathrm{CDCl}_{3}\right)$}

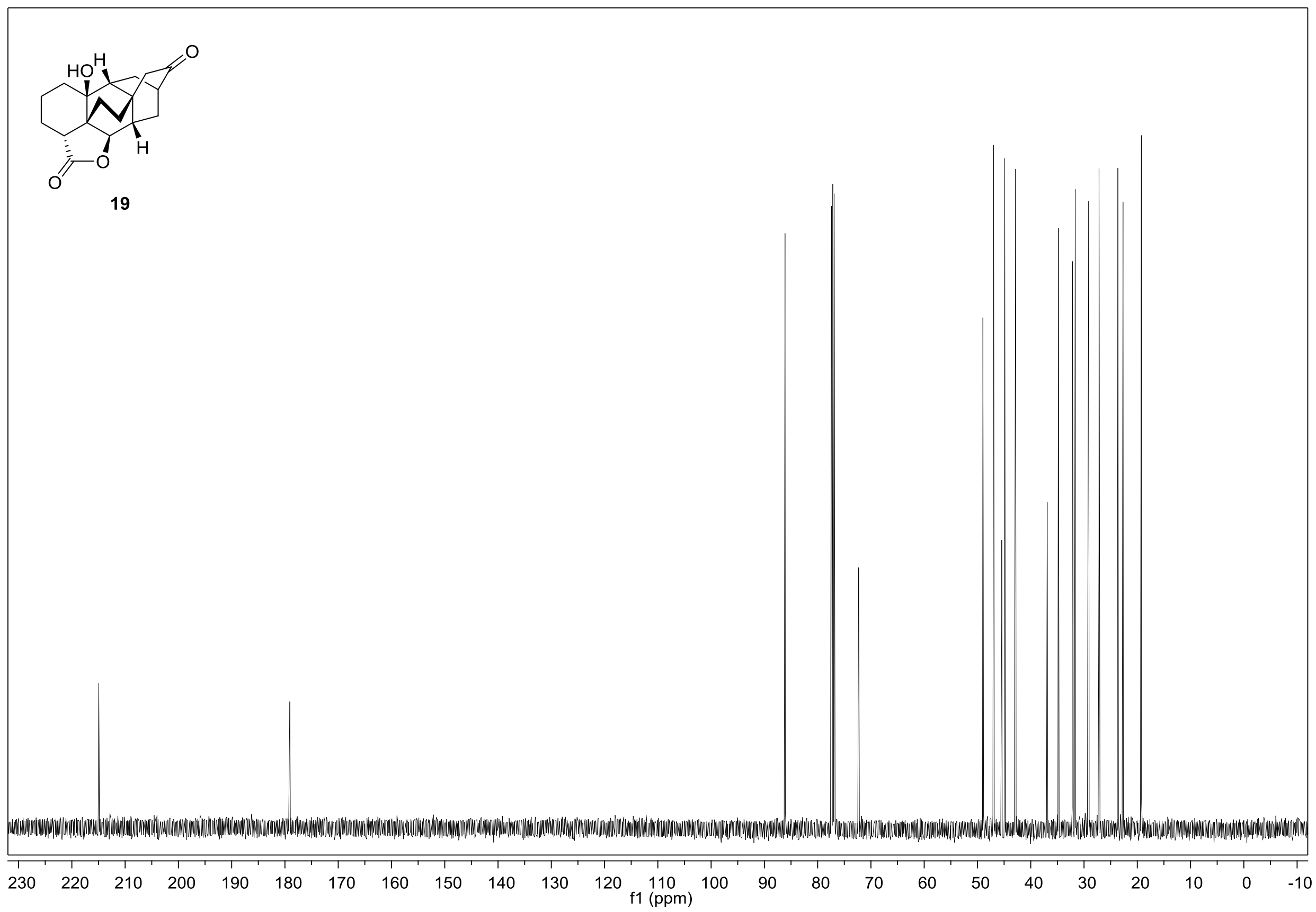


${ }^{1} \mathrm{H}$ NMR Spectrum of $20\left(500 \mathrm{MHz}, \mathrm{CDCl}_{3}\right)$

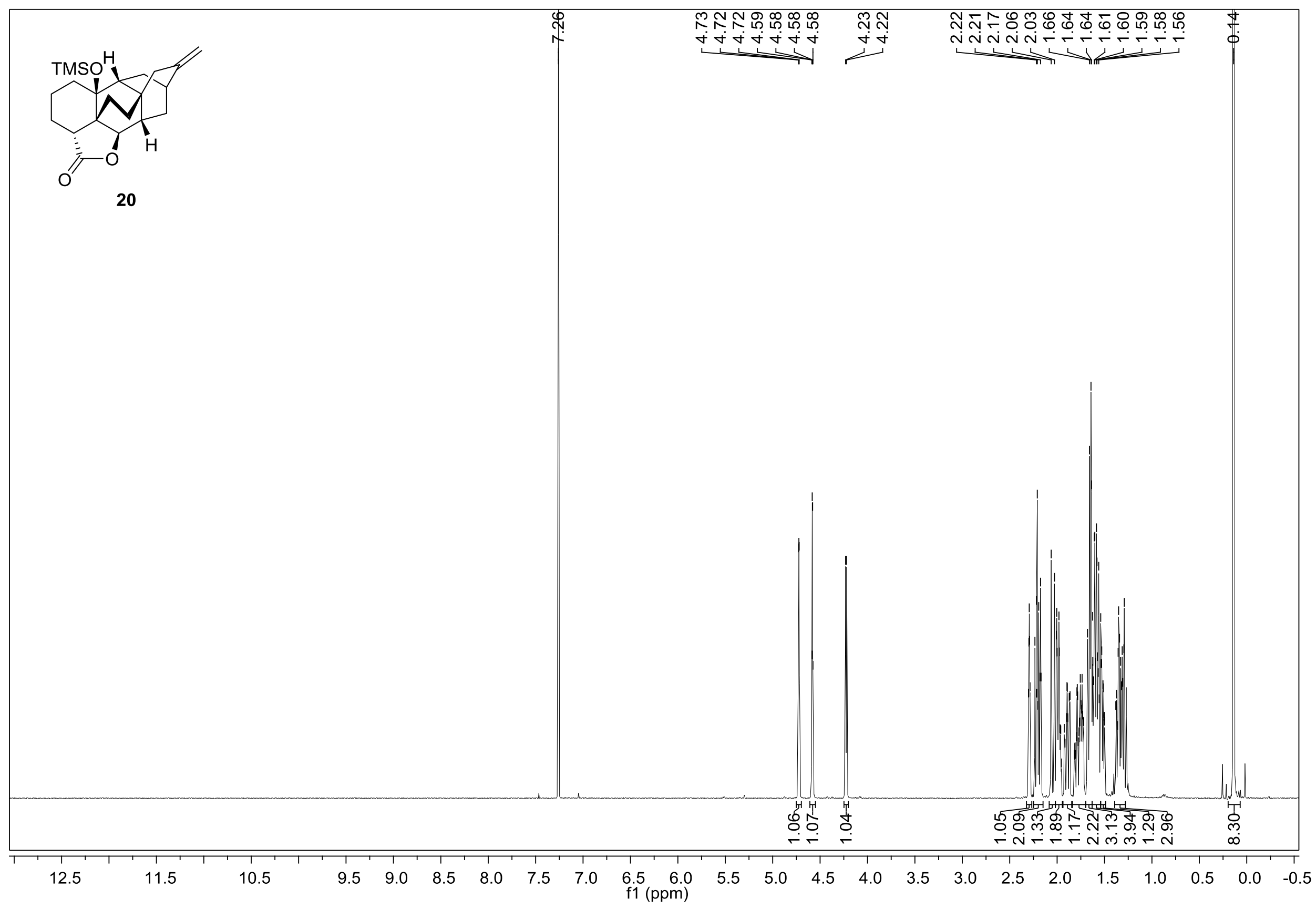




\section{${ }^{13} \mathrm{C}$ NMR Spectrum of $20\left(126 \mathrm{MHz}, \mathrm{CDCl}_{3}\right)$}

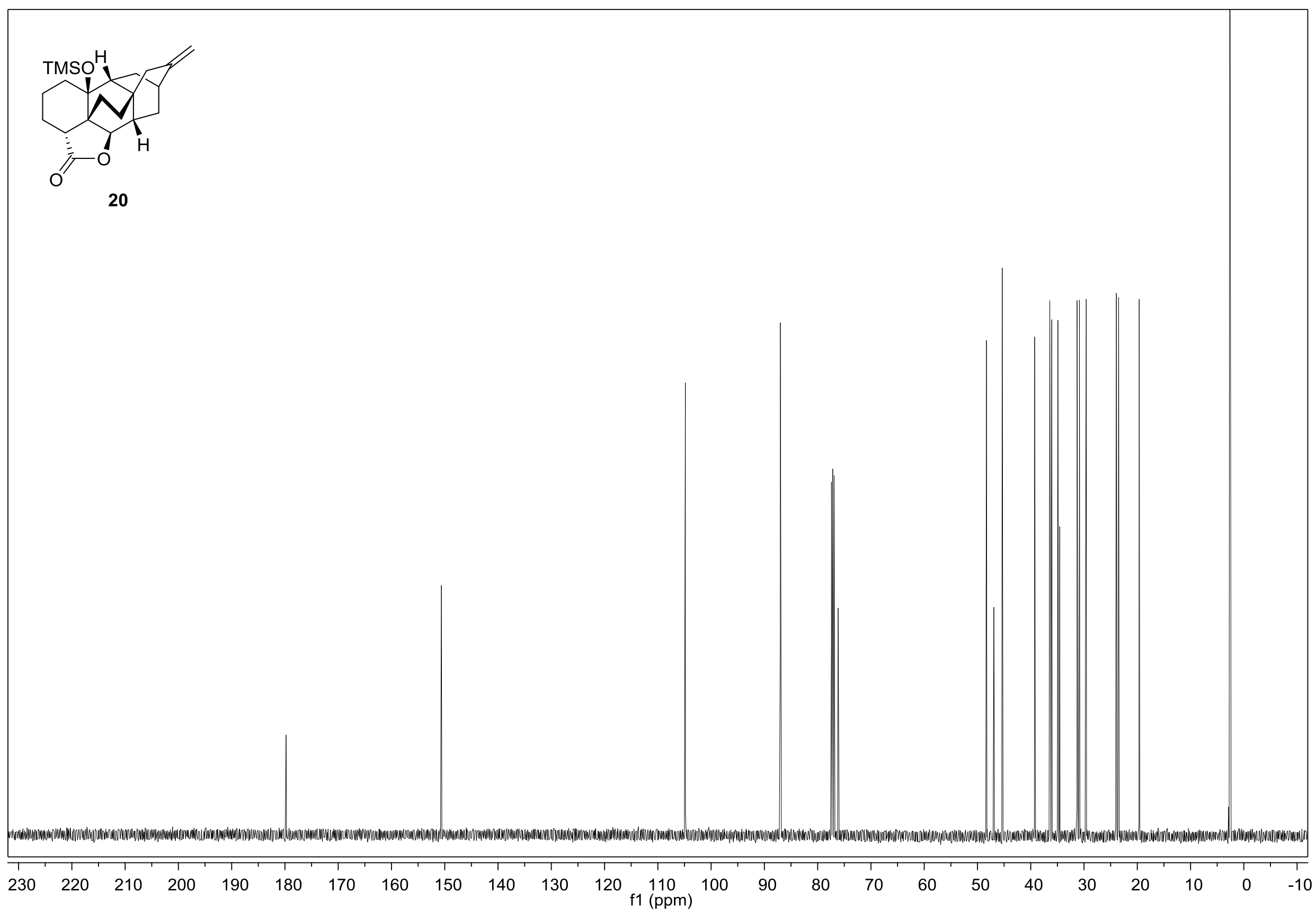


${ }^{1} \mathrm{H}$ NMR Spectrum of $21\left(500 \mathrm{MHz}, \mathrm{CDCl}_{3}\right)$

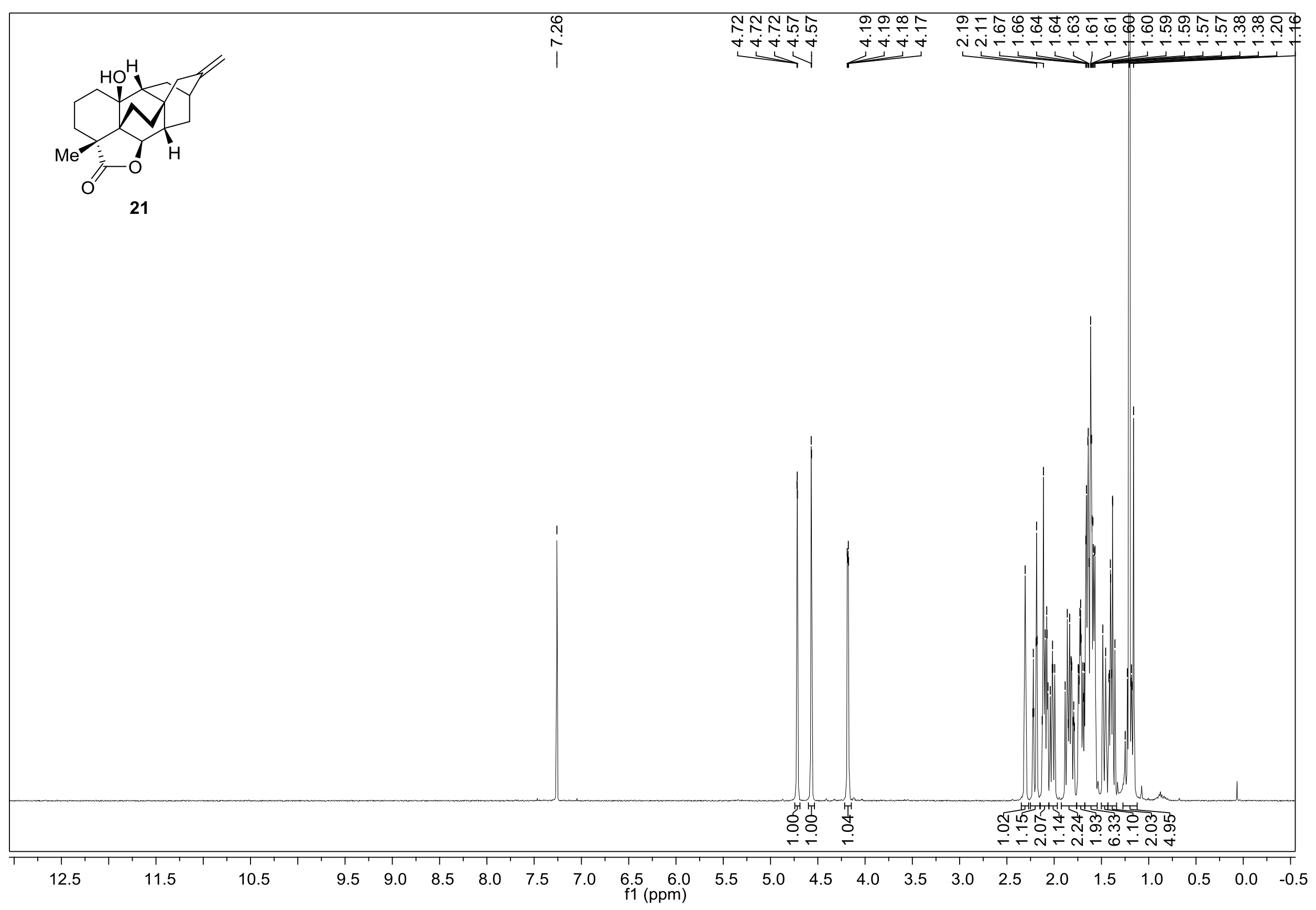


${ }^{13} \mathrm{C}$ NMR Spectrum of $21\left(126 \mathrm{MHz}, \mathrm{CDCl}_{3}\right)$

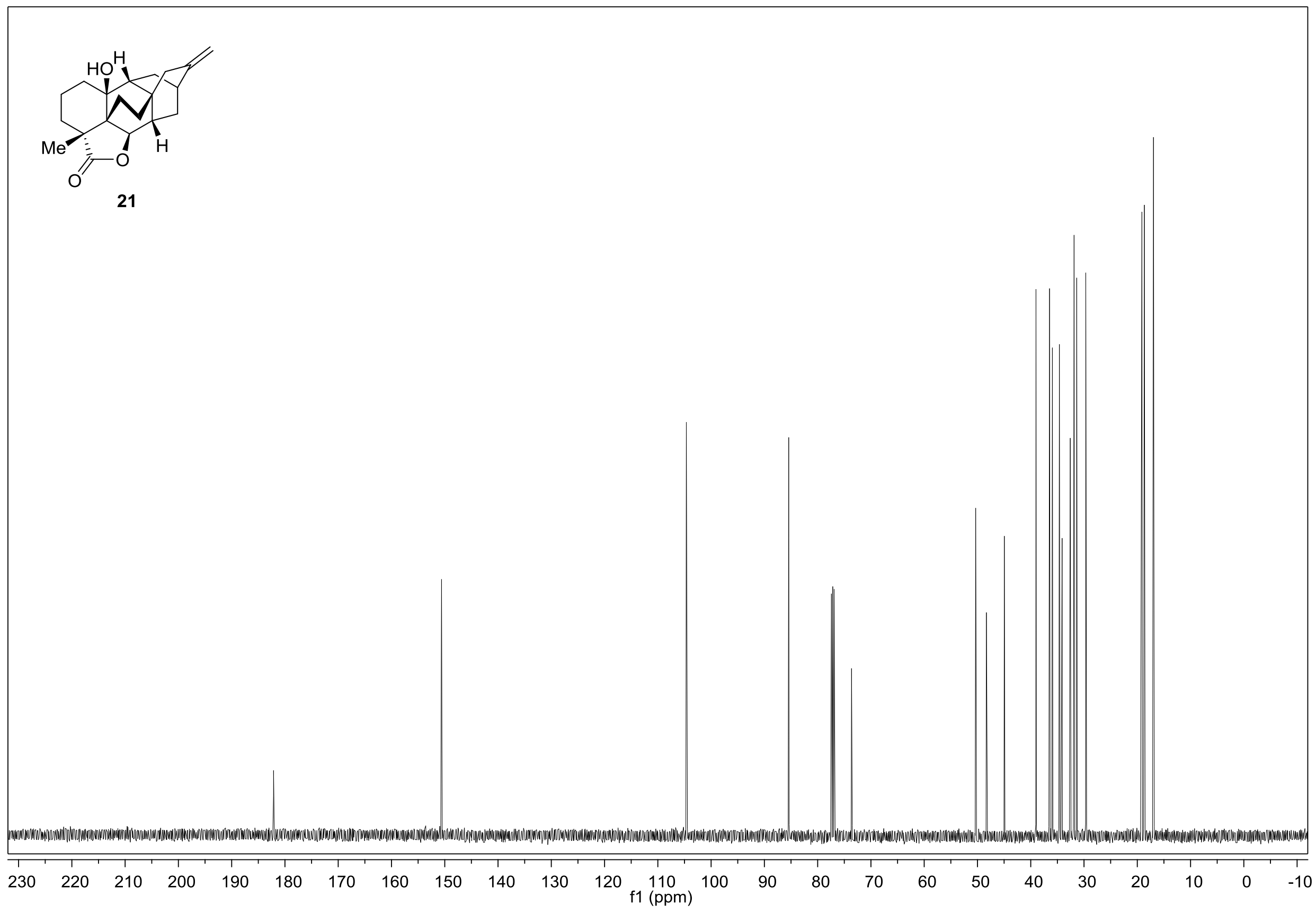


${ }^{1} \mathrm{H}$ NMR Spectrum of $22\left(400 \mathrm{MHz}, \mathrm{CDCl}_{3}\right)$

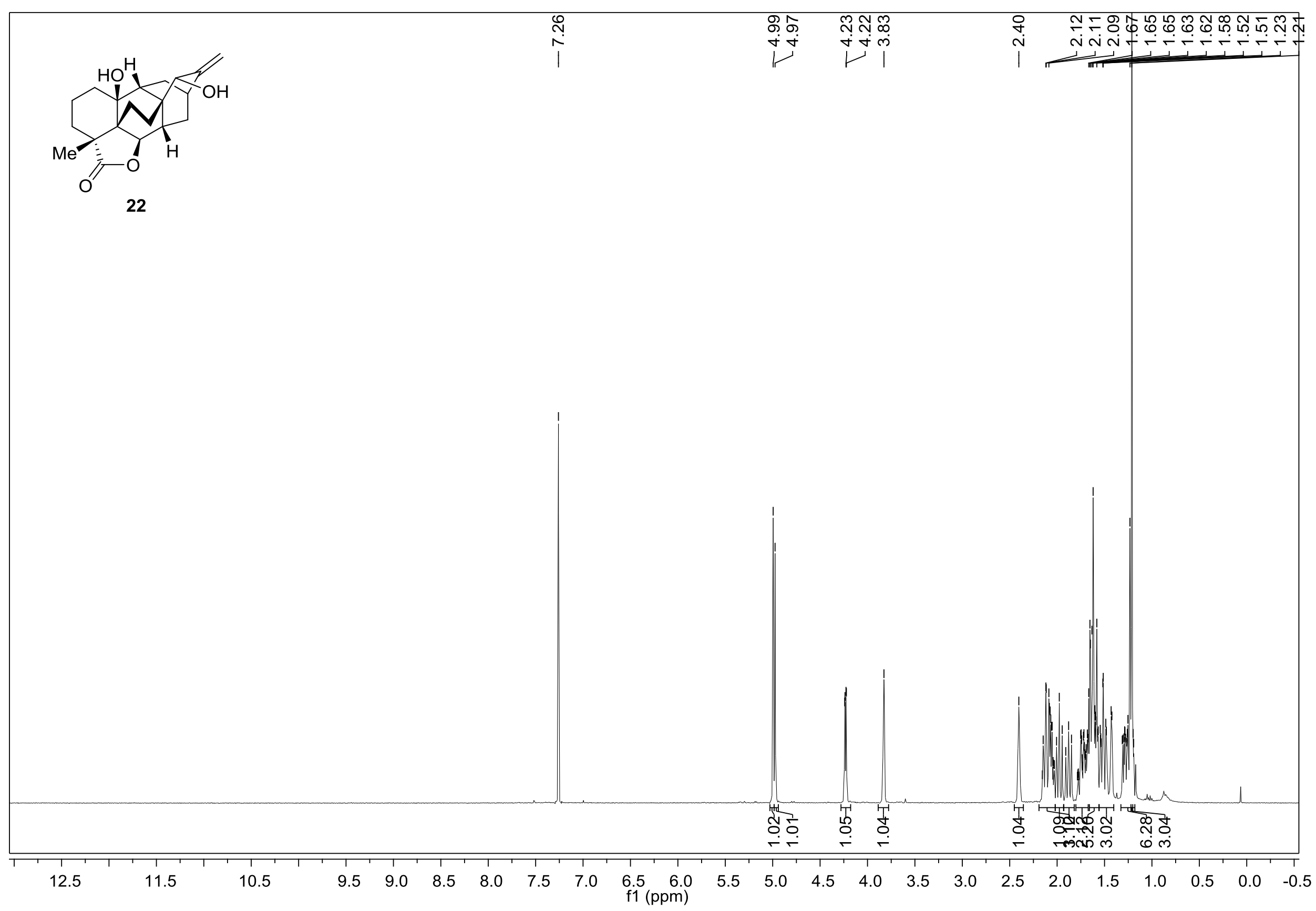


${ }^{13} \mathrm{C}$ NMR Spectrum of $22\left(126 \mathrm{MHz}, \mathrm{CD}_{3} \mathrm{COCD}_{3}\right)$

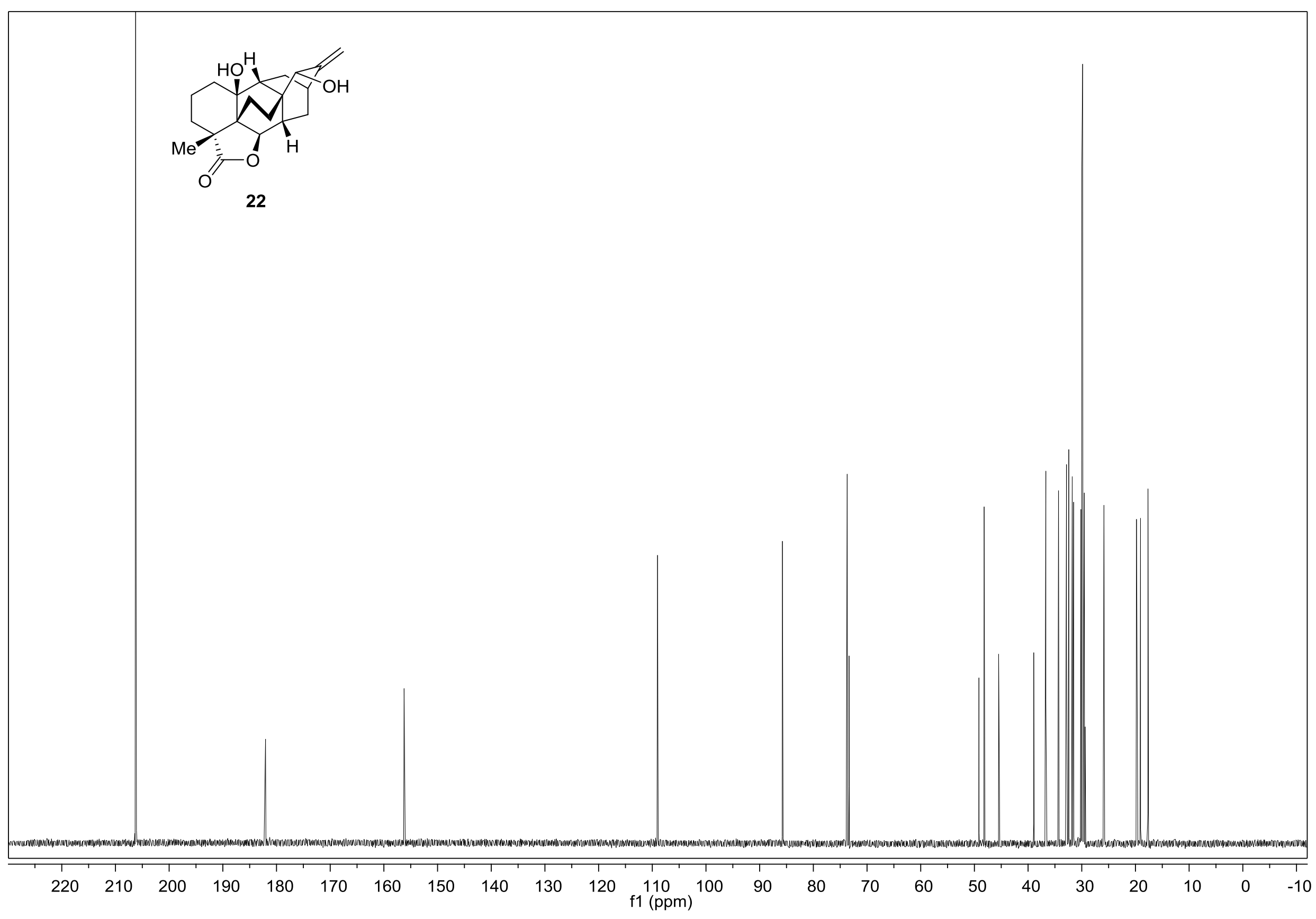




\section{${ }^{1} \mathrm{H}$ NMR Spectrum of $6\left(400 \mathrm{MHz}, \mathrm{CDCl}_{3}\right)$}

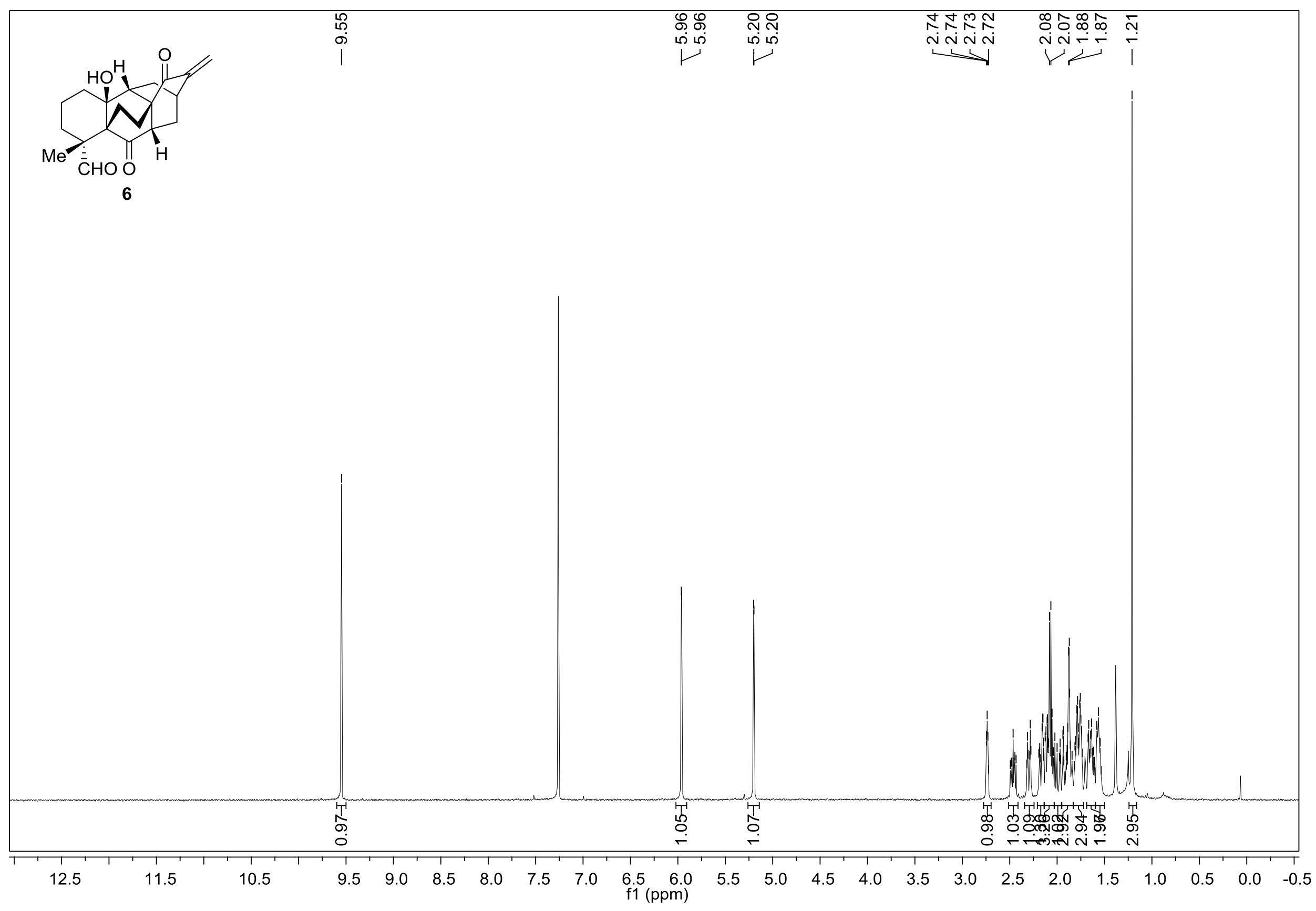




\section{${ }^{13} \mathrm{C}$ NMR Spectrum of $6\left(126 \mathrm{MHz}, \mathrm{CDCl}_{3}\right)$}

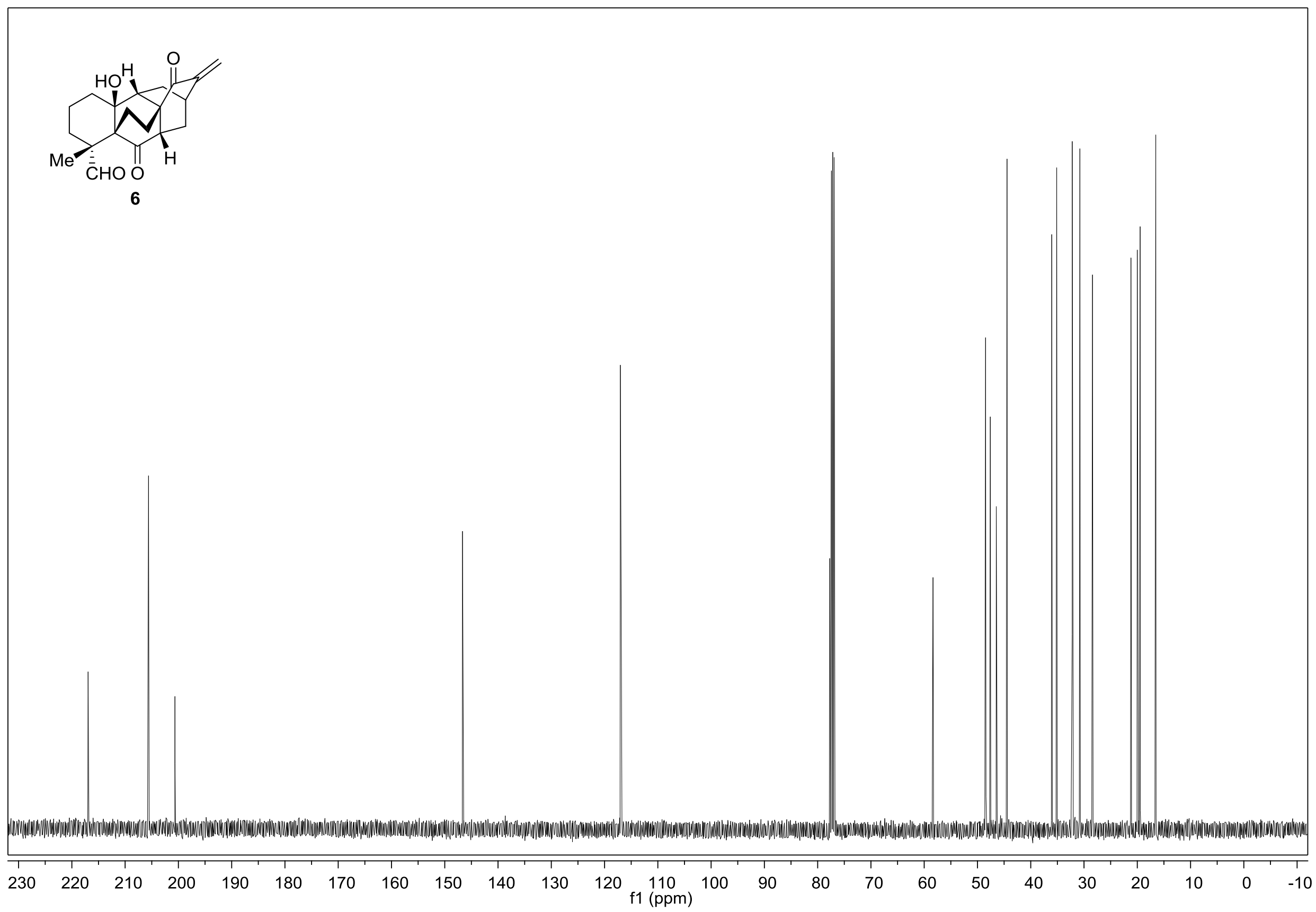


${ }^{1} \mathrm{H}$ NMR Spectrum of 23 (400 MHz, $\left.\mathrm{CD}_{3} \mathrm{OD}\right)$

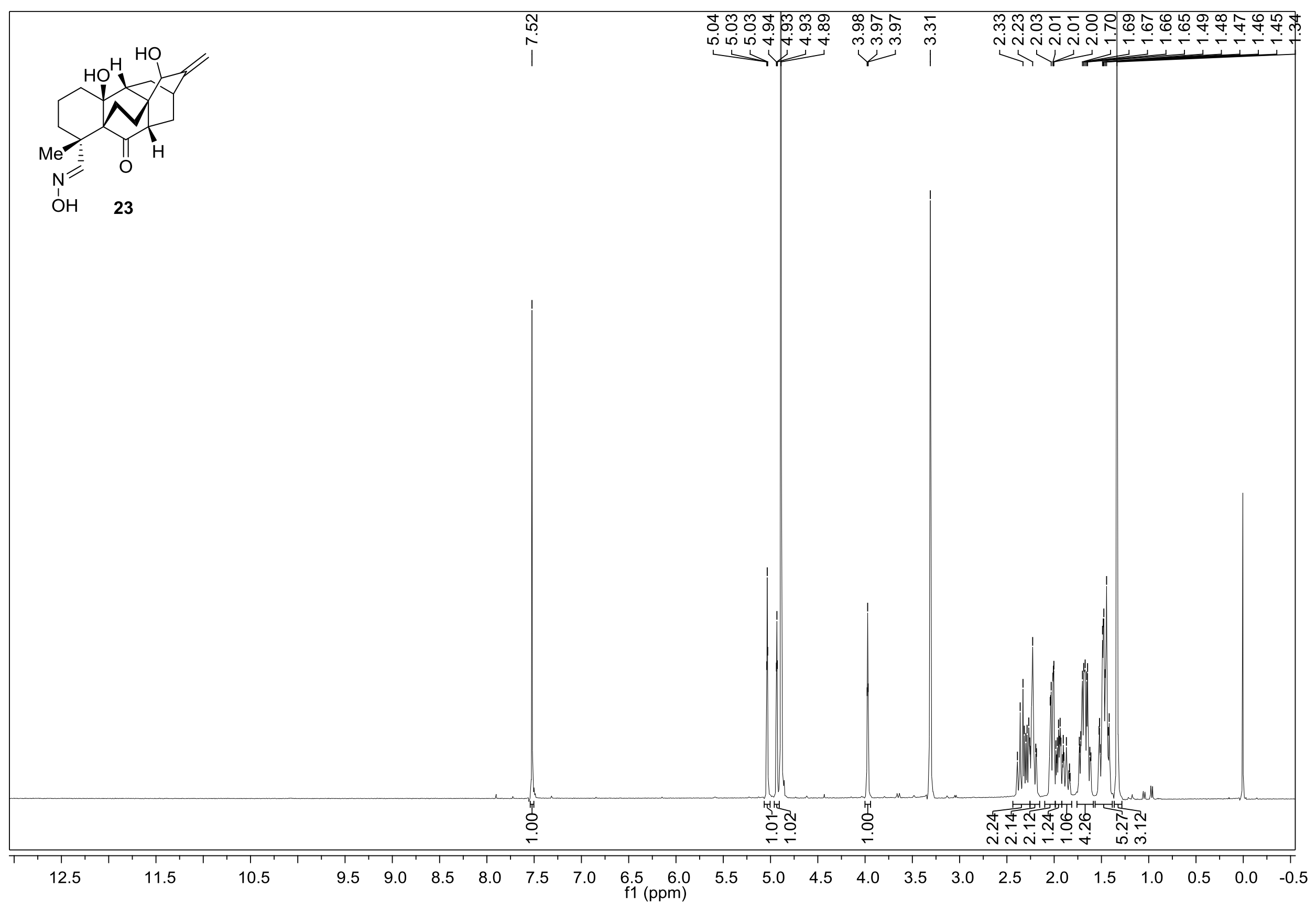


${ }^{13} \mathrm{C}$ NMR Spectrum of $23\left(126 \mathrm{MHz}, \mathrm{CD}_{3} \mathrm{OD}\right)$

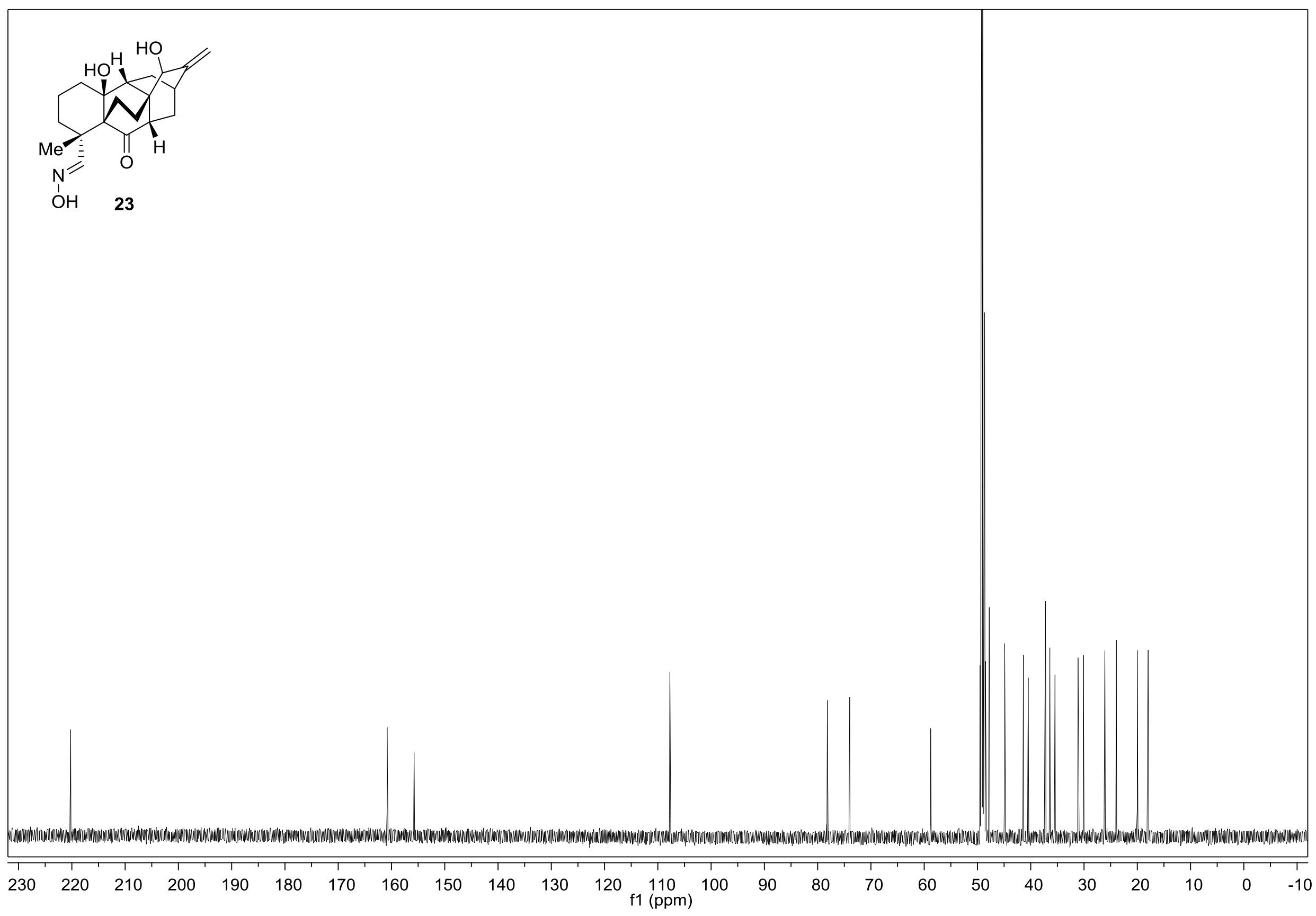


${ }^{1} \mathrm{H}$ NMR Spectrum of $3\left(500 \mathrm{MHz}, \mathrm{CDCl}_{3}\right)$

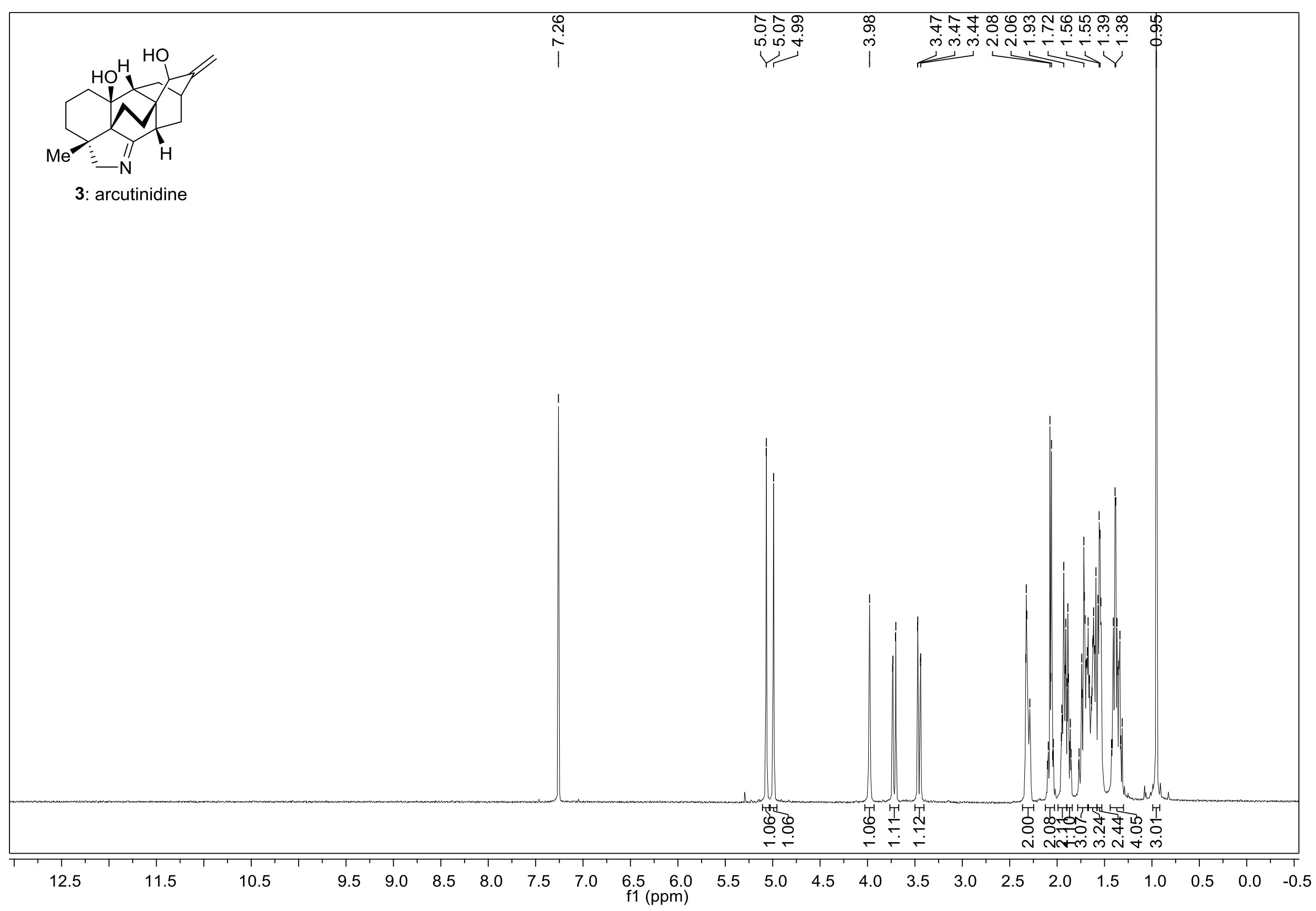


${ }^{13} \mathrm{C}$ NMR Spectrum of $3\left(126 \mathrm{MHz}, \mathrm{CDCl}_{3}\right)$

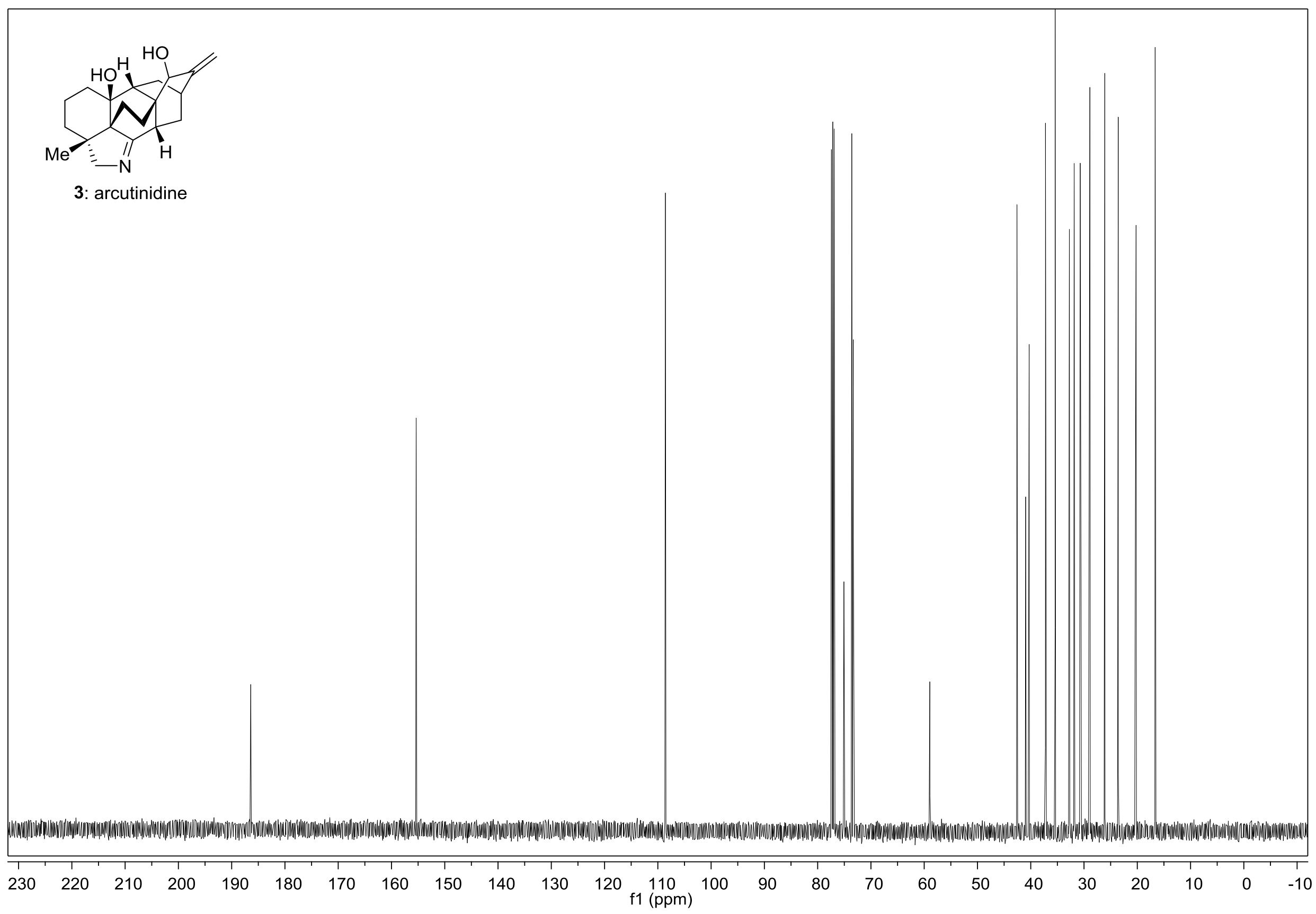


${ }^{1} \mathrm{H}$ NMR Spectrum of $2\left(400 \mathrm{MHz}, \mathrm{CDCl}_{3}\right)$

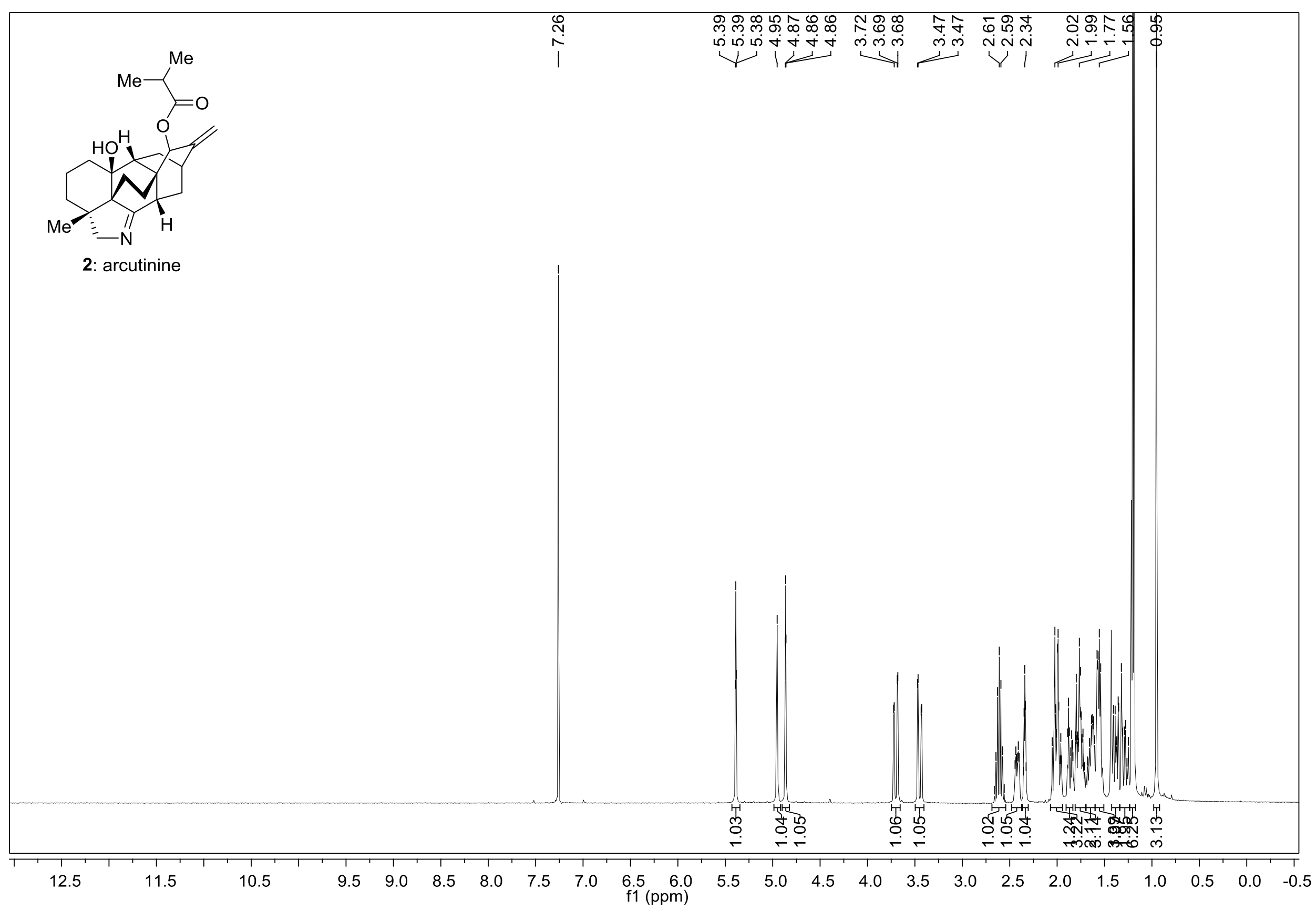


${ }^{13} \mathrm{C}$ NMR Spectrum of $2\left(126 \mathrm{MHz}, \mathrm{CDCl}_{3}\right)$

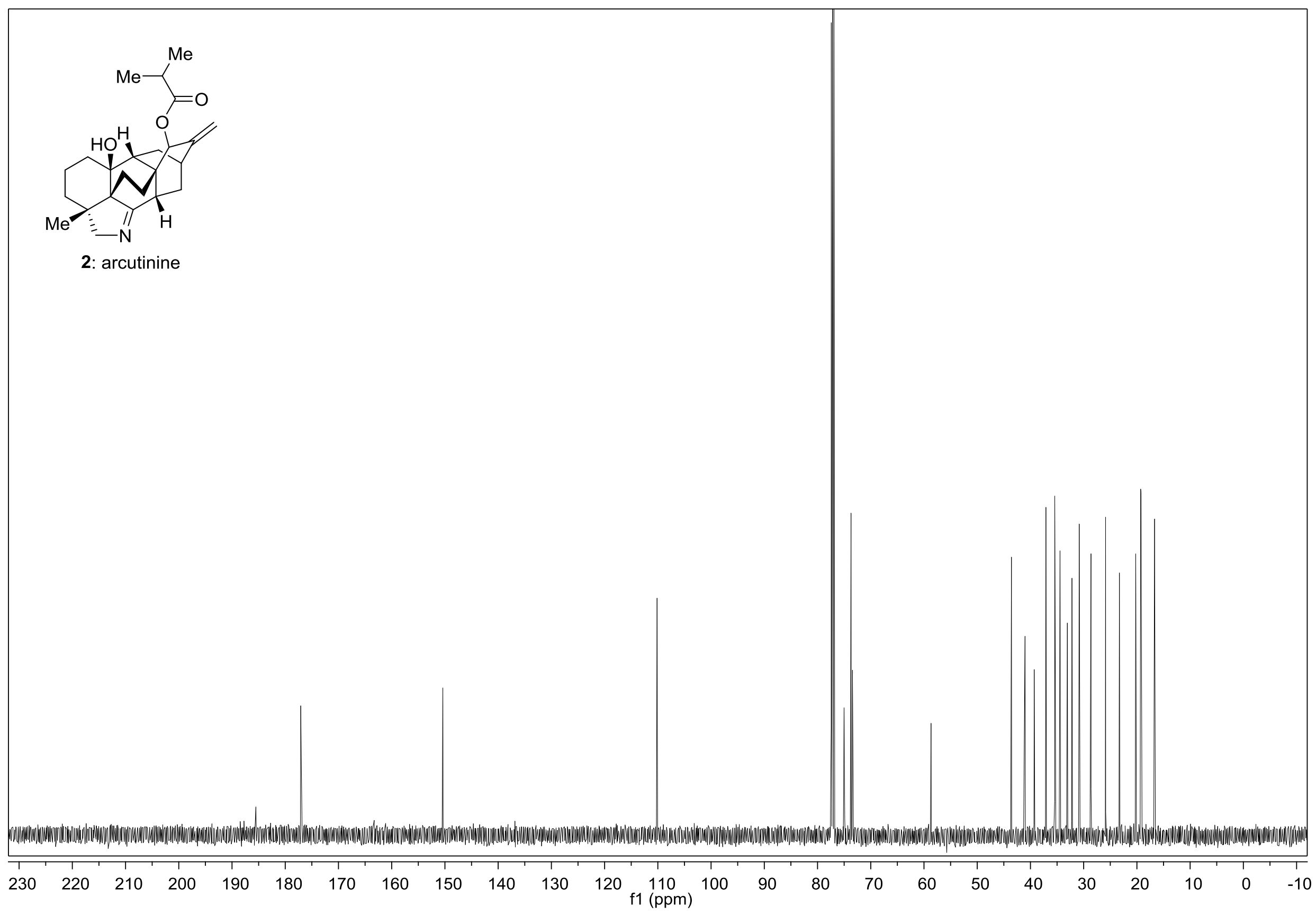


(1) Shih, C.; Swenton, J. S. Use of protected $\beta$-bromocyclopentenones and $\beta$-bromocyclohexenones as $\beta$-acylvinyl anion equivalents. J. Org. Chem. 1982, 47, 2825.

(2) Attolini, M.; Bouguir, F.; Iacazio, G.; Peiffer, G.; Maffei, M. Enantioselective synthesis of cyclic dialkyl (3-hydroxy-1-alkenyl) phosphonates by baker's yeast-mediated reduction of the corresponding enones. Tetrahedron 2001, 57, 537.

(3) (a) O’Byrne, A.; Murray, C.; Keegan, D.; Palacio, C.; Evans, P.; Morgan, B. S. The thio-adduct facilitated, enzymatic kinetic resolution of 4-hydroxycyclopentenone and 4-hydroxycyclohexenone. $\mathrm{Org}$. Biomol. Chem. 2010, 8, 539. (b) Li, J.; Zhang, W.; Zhang, F.; Chen, Y.; Li, A. Total synthesis of daphniyunnine C (longeracinphyllin A). J. Am. Chem. Soc. 2017, 139, 14893.

(4) Carreño, M. C.; Urbano, A.; Di Vitta, C. Enantioselective Diels-Alder approach to C3-oxygenated angucyclinones from (SS)-2-(p-tolylsulfinyl)-1,4-naphthoquinone. Chem. Eur. J. 2000, 6, 906.

(5) Seyferth, D.; Weiner, M. A. The preparation of organolithium compounds by the transmetalation reaction. I. vinyllithium. J. Am. Chem. Soc. 1961, 83, 3583.

(6) Ratcliffe, R.; Rodehorst, R. Improved procedure for oxidations with the chromium trioxide-pyridine complex. J. Org. Chem. 1970, 35, 4000. 
